Journal of Social Sciences (COES\&RJ-JSS)

ISSN (E): 2305-9249 ISSN (P): 2305-9494

Publisher: Centre of Excellence for Scientific \& Research Journalism, COES\&RJ LLC

Online Publication Date: $1^{\text {st }}$ April 2019

Online Issue: Volume 8, Number 2, April 2019

https://doi.org/10.25255/jss.2019.8.2.230.269

\title{
The Influence of Organizational Justice on Job Commitment in the
} Jordanian Ministries

Yazan Taher Shawabkeh

An Independent Researcher, Amman, Jordan, yazanshwabkeh@gmail.com

Musa Al-Lozi

Department of Public Administration, School of Business, The University of Jordan, Amman, Jordan \& President of Aqaba Branch, The University of Jordan, Aqaba, Jordan

Lozi.musa@ju.edu.jo

Ra'ed Masa'deh

Department of Management Information Systems, School of Business, The University of Jordan, Amman, Jordan, r.masadeh@ju.edu.jo

\section{Abstract:}

The aim of this study was to investigate the impact of organizational justice on job commitment in Jordanian ministries. Data were collected through a questionnaire distributed to 450 employees in three Jordanian ministries, namely, the Ministry of Education; Ministry of Health; and Ministry of Awqaf Islamic Affairs and Holy Places. Data were analyzed via descriptive, simple linear regression analysis, and stepwise multiple linear regression analysis. The hypotheses of the research were tested and the probabilities of their acceptance were rejection. Findings revealed a statistically significant impact between organizational justice and job commitimnt. Results also indicated that informational justice has the highest influential effect on employee job commitmint, while procedural justice had the lowest impact on it. Furthermore, this study reports differences between the dimensions of the (OJ) in their impacts on the dimensions of job commitment. Moreover, the study found that the three dimensions of organizational justice (information justice, personal justice, and distributive justice) combined had a higher predictive capacity of job commitment than that of any independent dimension or two dimensions of organizational justice. In view of the results, the researcher gives some recommendations to the decision makers in Jordanian ministries that may guide them to promote the concept and practice of organizational justice in their ministries such as the need for increasing the levels of organizational justice, especially the distributive justice, and focusing on compatibility of income of the employee with their academic level and practical experience, in addition to necessity of improving the system of rewards in the Jordanian ministries because the rewards have a significant impact on the employees' perception of justice and on her/his interest in supporting her/his colleagues when doing additional work in the ministry. In other respects, this study has practical implications for future research such as attracting attention to the need to study job satisfaction and job engagement as mediatingvariables of association of employee's job commitment with organizational justice. This is in addition to conducting studies similar to the present one in different environments inside and outside Jordan.

\section{Keywords:}

Organizational Justice, Job Commitment, Ministries

This work is licensed under a Creative Commons Attribution 4.0 International License. 


\section{Citation:}

Shawabkeh, Yazan Taher; Al-Lozi, Musa; Masa'deh Ra'ed (2019); The Influence of Organizational Justice on Job Commitment in the Jordanian Ministries; Journal of Social Sciences (COES\&RJ-JSS), Vol.8, No.2, pp:230-269; https://doi.org/10.25255/jss.2019.8.2.230.269.

\section{أثر العدالة التظيمية في الالتزام الوظيفي في الوزارات الأردنية}

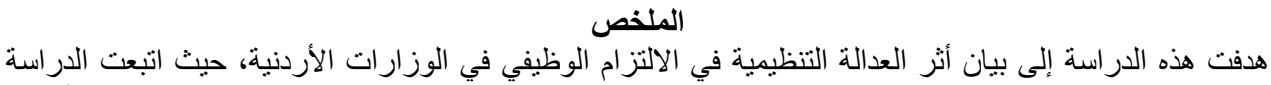

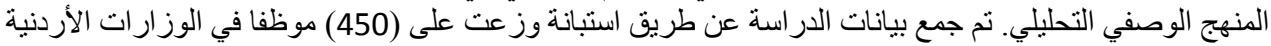

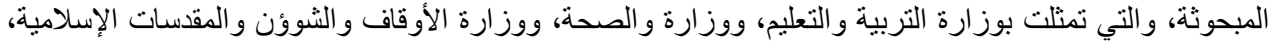

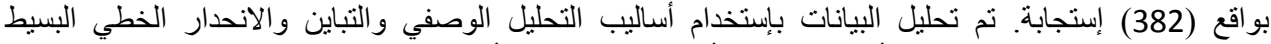

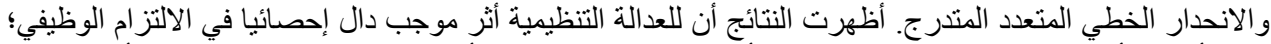

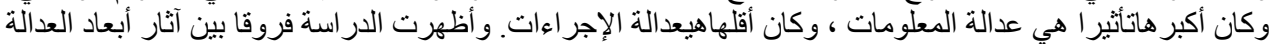

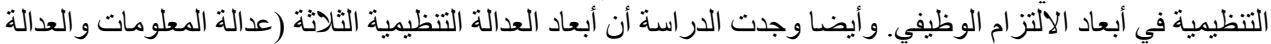

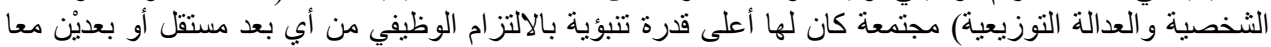

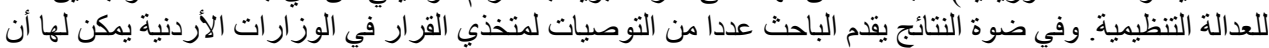

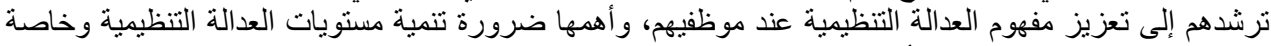

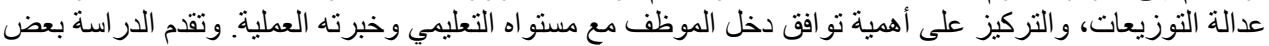

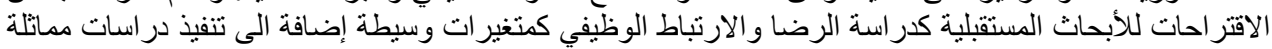

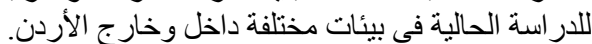
كلمات مفتاحية: العدالة التنظيمية، الإلتز ام الوظيفي، الوالتية الوزارات الأردنية، الأردن.

1.1 1 1 المقدمة

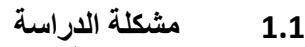

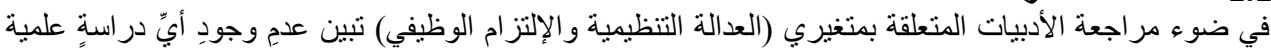

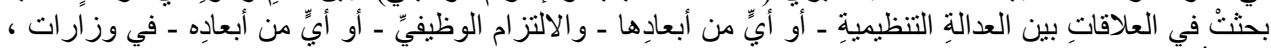

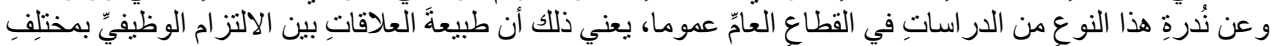

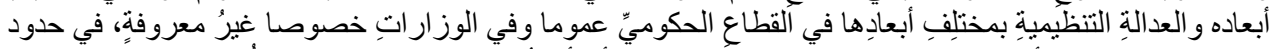

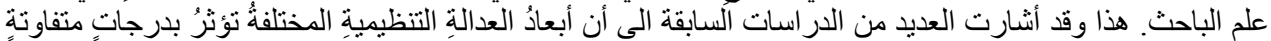

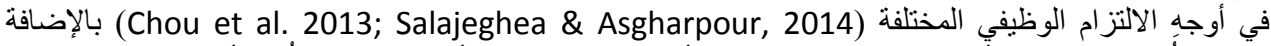

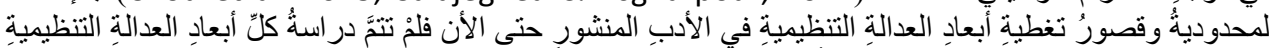

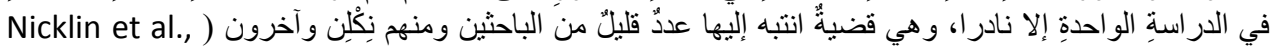

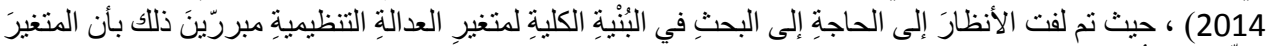

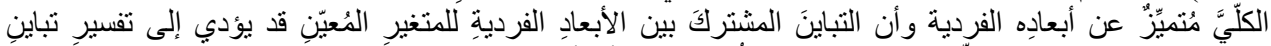

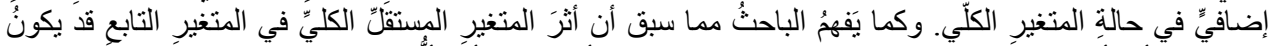

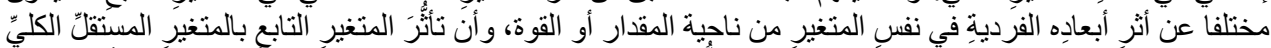

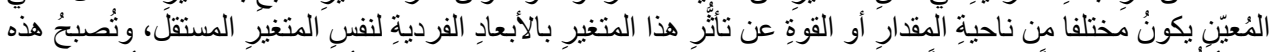

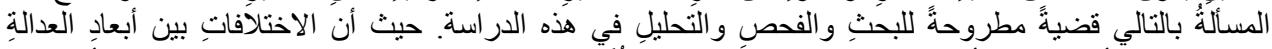

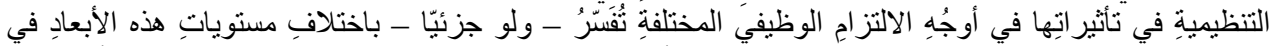

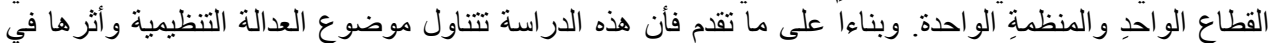
الإلتز ام الوظيفي في الوزار الوات الأردنية.

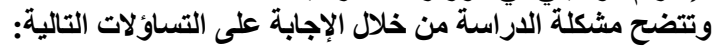

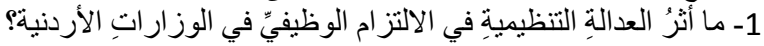

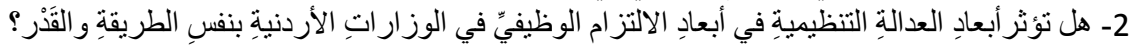
1.2 في ضو اء مشكلة الدر اسة تسعى الدراسة الحالية الحالية للإجابة عن الأسئلة التالية:

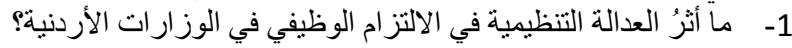
ويتفرع من هذا السؤال عدة اسئلة فرعية: 
ما أثر عدالة التوزيعات في الالتز ام الوظيفي في الوزار التوات الأردنية؟

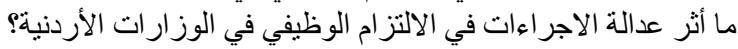

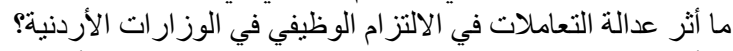

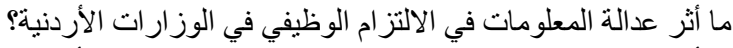

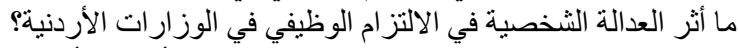

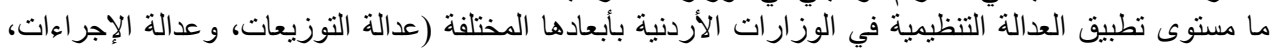

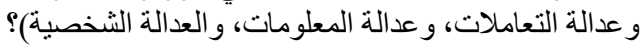

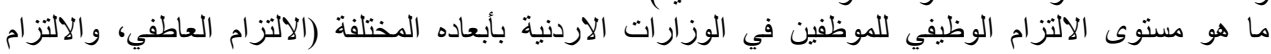

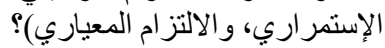

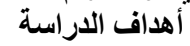

تهدف هذه الدراسة الى تبيان أثر العدالة التنظيمية في الالتزام الوظيفي في الوزارات الأردنية، وينبثق عن هذا الهدف الرئيس الأهداف الفرعية التالية:

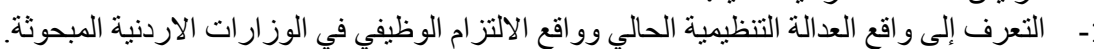

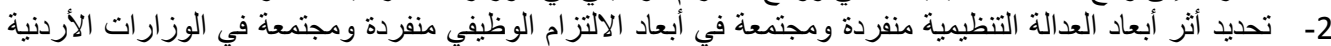

طوّر الباحث نموذجا عاما للار اسة يوضح المتغير ات المستقلة و المتغير التابع وطبيعة العلاقات بينها.

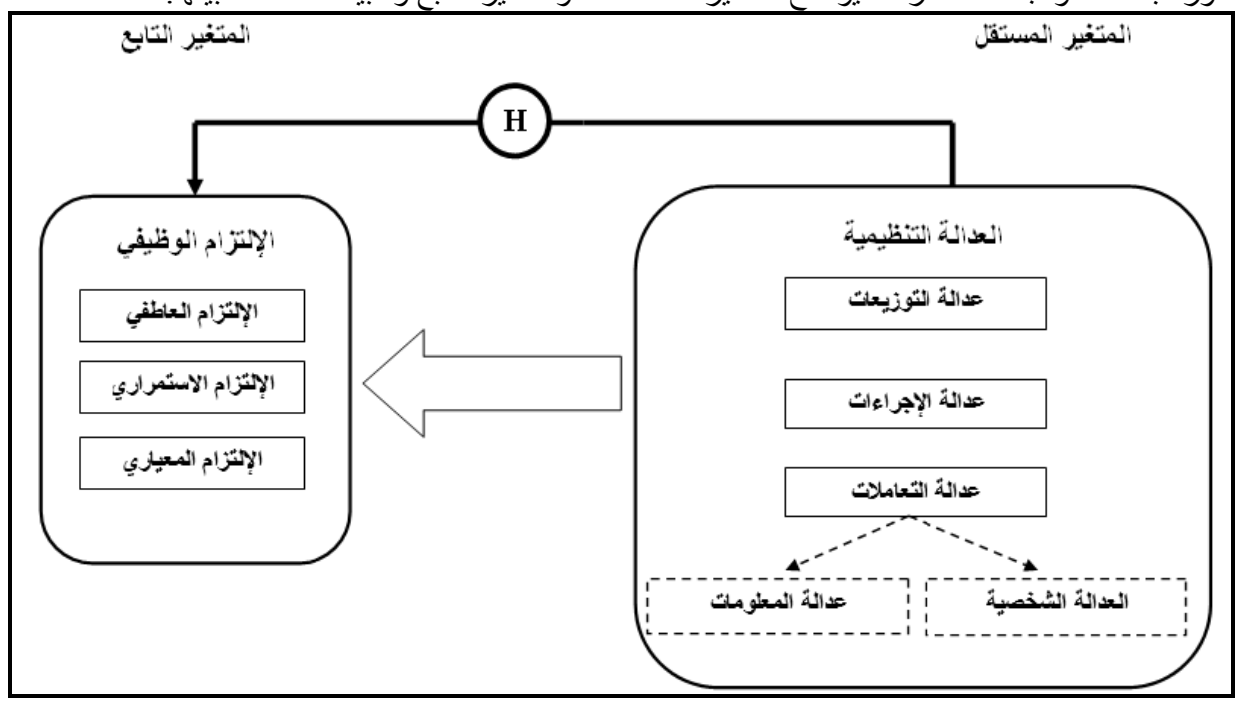

الثكل (1). نموذج الدراسة

هذا النموذج من تصميم الباحث لأغر اض هذه الدر اسة بالإستنارة بعدد من الدراسات السابقة و أهمها در اسات

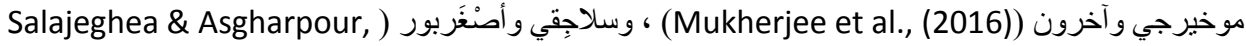
2014) ، وشوو وشوو وجيانغ وكلاين (2013 (2013 (Chou, Chou, Jiang, \& Klein).

1.5 تعريف متغيرات الدراسة الإصطلاحية والإجرائية

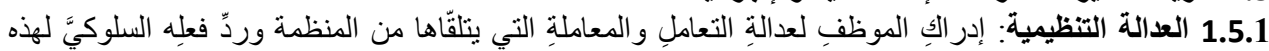

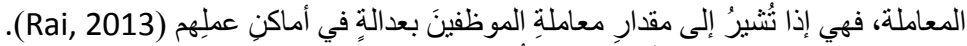

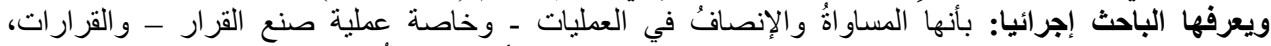

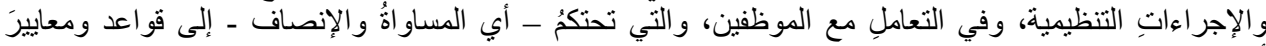
أخلاقية راسخة راسخة.

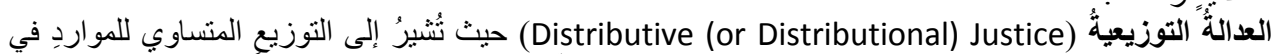

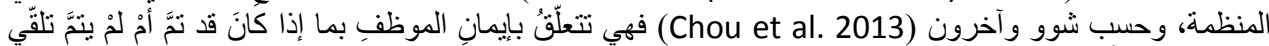

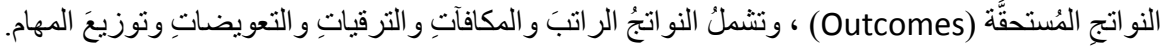


عدالة الإجراءات (Procedural Justice) حيث تدلُ على مستوى العدالة الذي يسود خلال تنفيذ مختلف العملياتِ

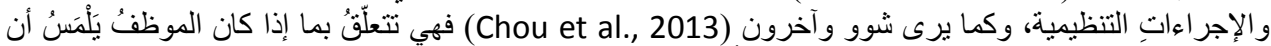

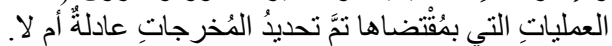

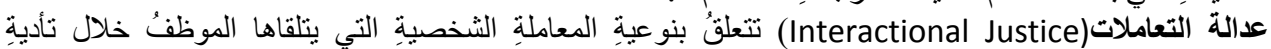
إجر اءاتِ العملِ في المنظمة (Chou et al., 2013; Nicklin et al., 2014; Mukherjee et al., 2016) حيث

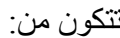

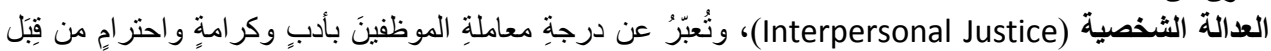

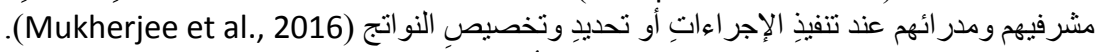

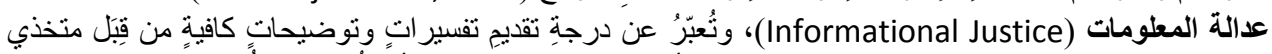

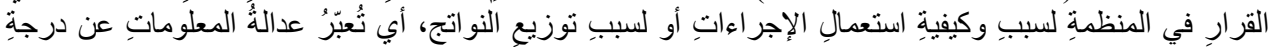

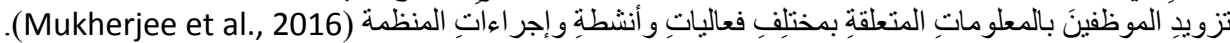

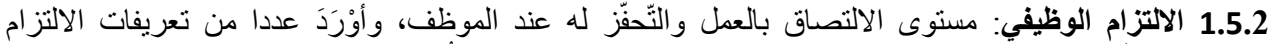

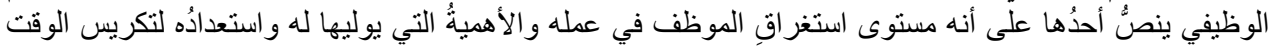

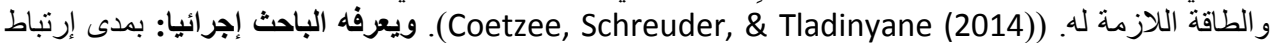

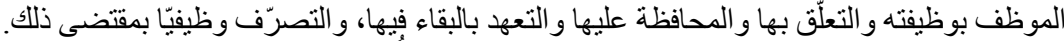

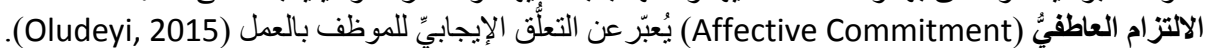

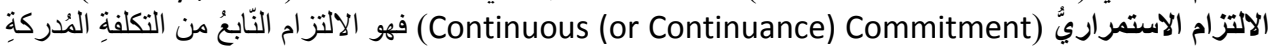
المرتبطة بترك العمل (Oludeyi, 2015). الالتزام المعياريُّ (Normative Commitment) هو ارتباطُ الموظف بالمنظمة بناء على تقييم المنافع الاقتصادية

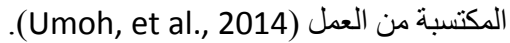
1.6 فرضيات الاراسة

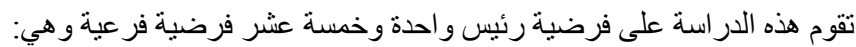

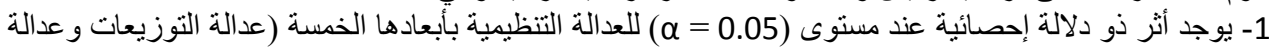

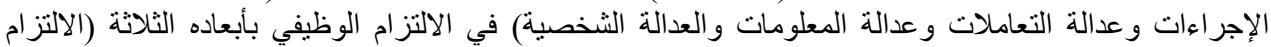

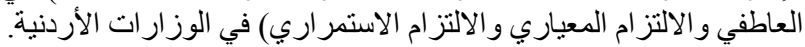

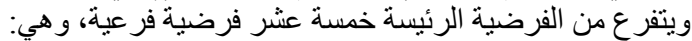

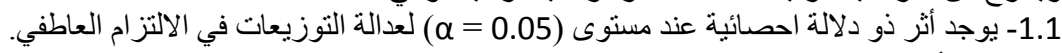

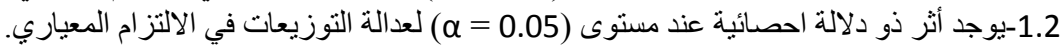
1.3-يوجد أثر ذو دلالة احصائية عند مستوى (1.20.0.

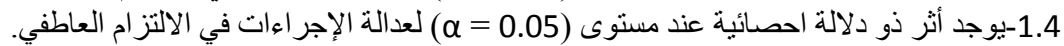

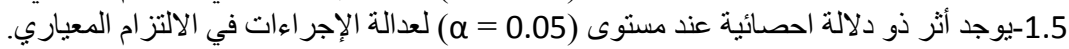

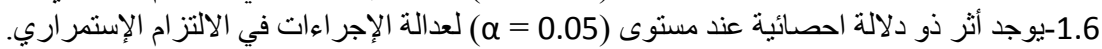

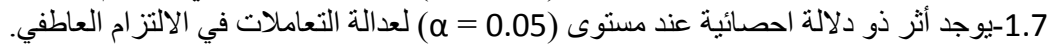

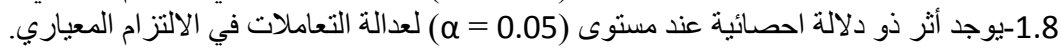

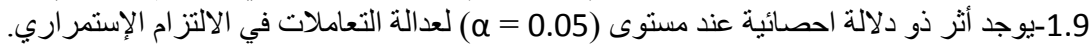

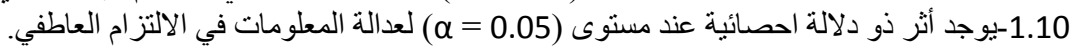

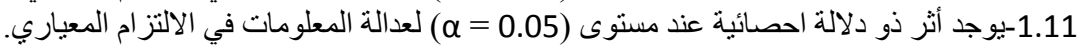

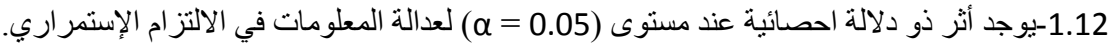

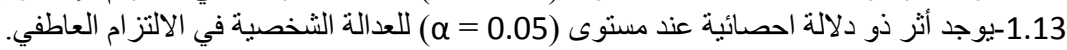

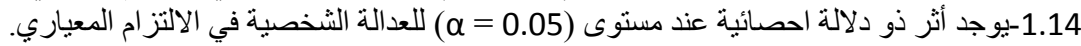

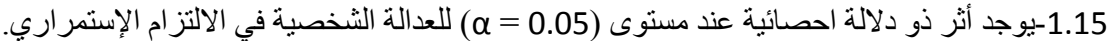

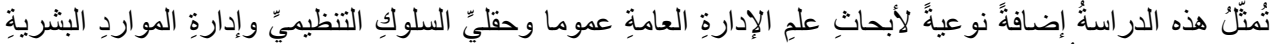

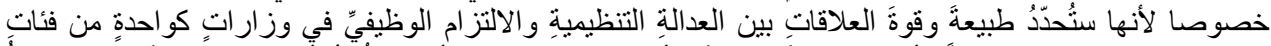

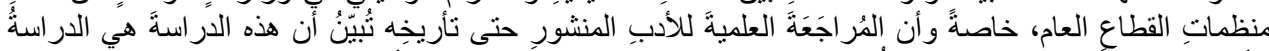

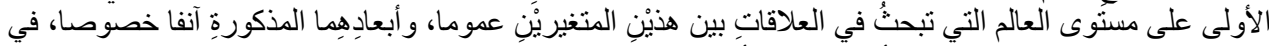

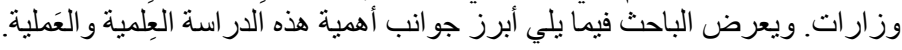




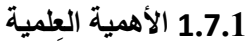

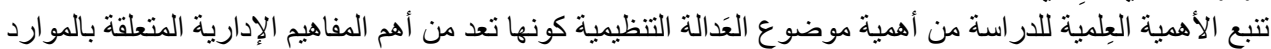

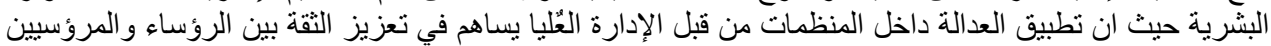

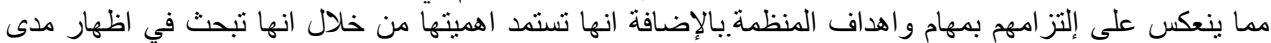

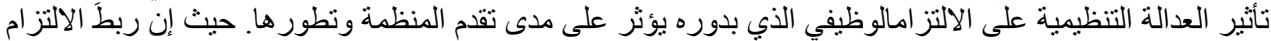

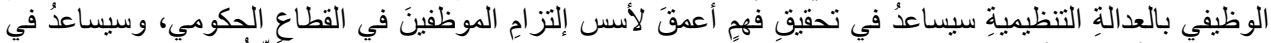

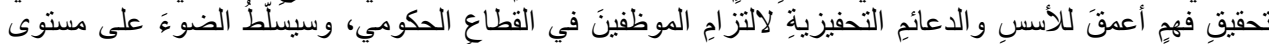

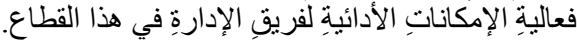

1.7.2 الأهمية العملية الأبية

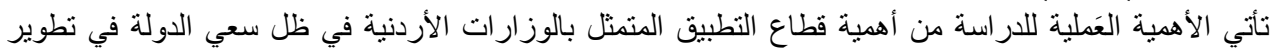

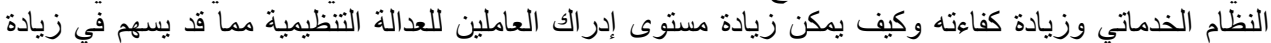

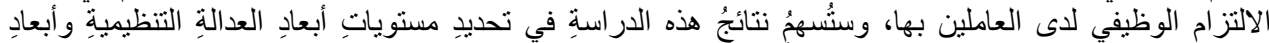

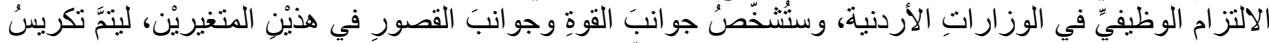

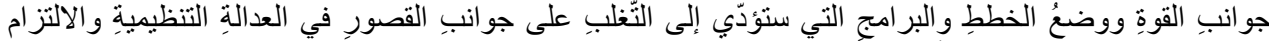

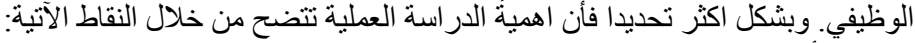

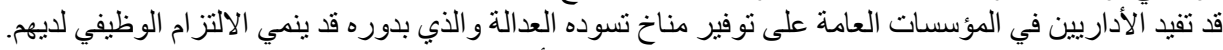

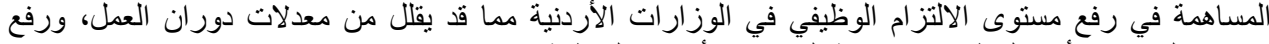

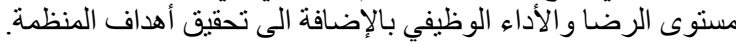

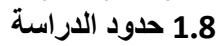

تتحذّد هذه الدر اسة بالحدود التالية:

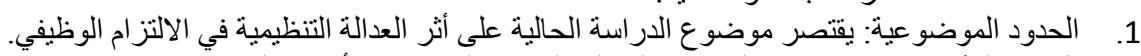

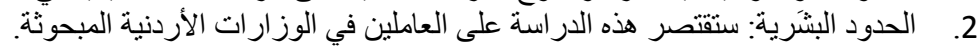
3.

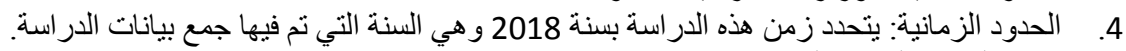

2 2

3

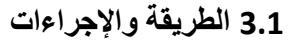

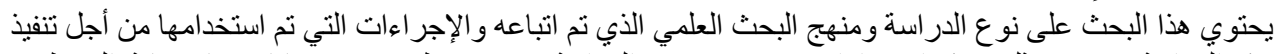

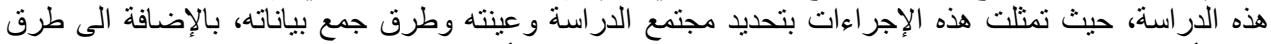

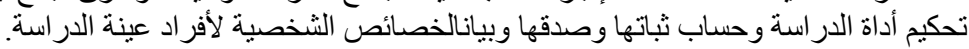

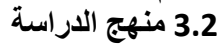

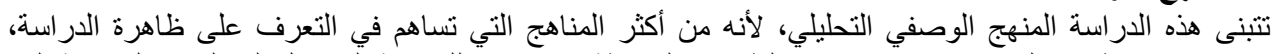

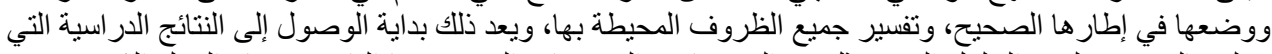

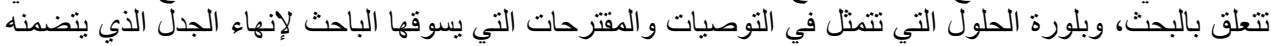

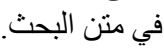

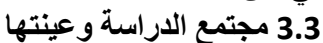

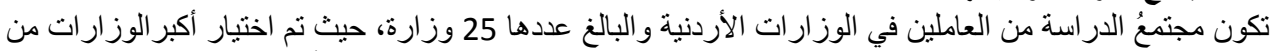

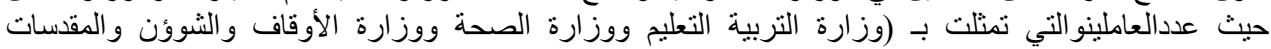

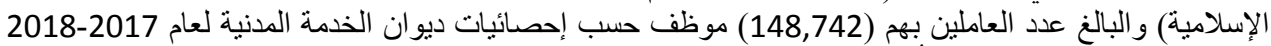

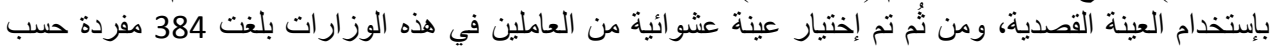

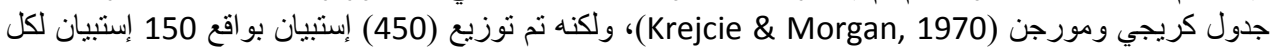

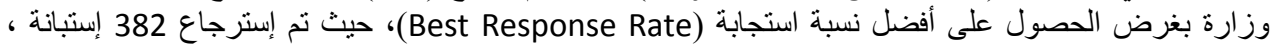

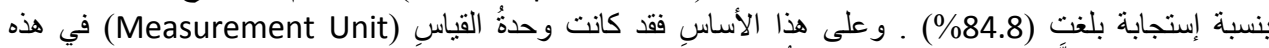

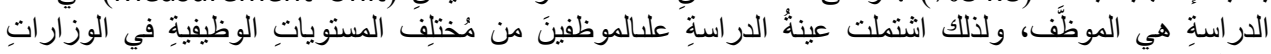

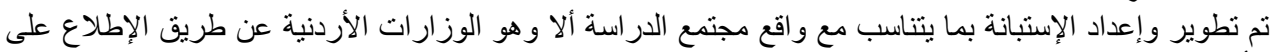

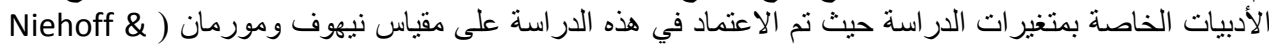

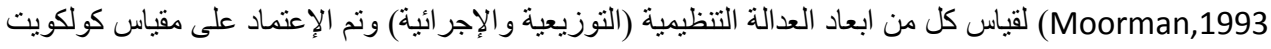




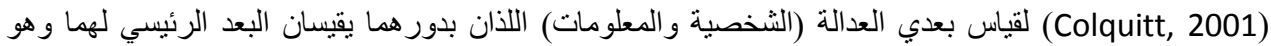

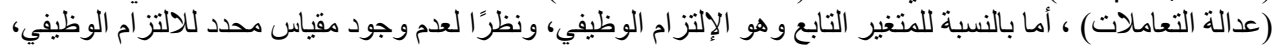

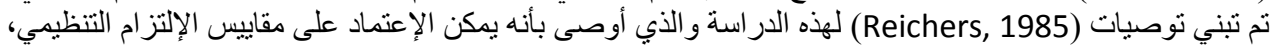
أوتعديلّها بشكل مبرر ليعكس الإلتزام الوظيفي ولذلك نم الإعتماد على مقياس (Mowday et al., 1982) من ألجل الإنل

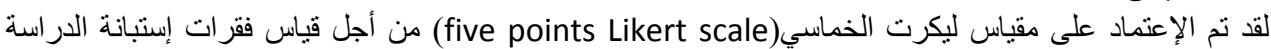

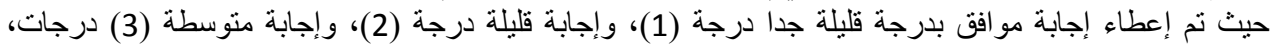

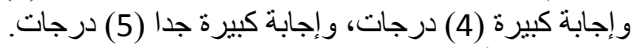

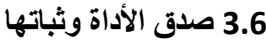

3.6.1 صدق أداة الاراسة الظاهري (Face validity)

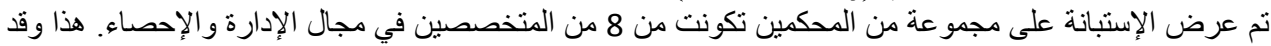

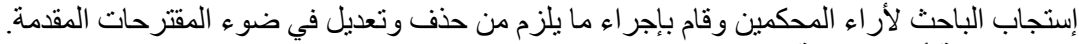

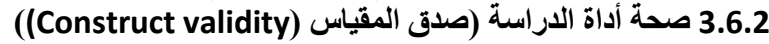

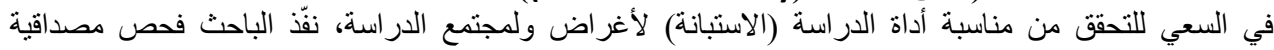

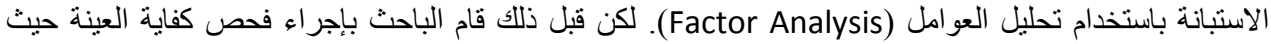
كaiser-Meyer-Olkin Measure of Sampling ) كانت قيمة معامل (أو مقياس) قيصر -ماير -أولكن لكفاية العينة (Adequacy

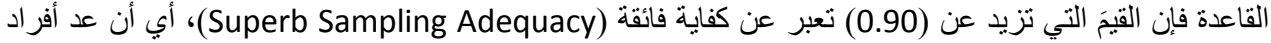

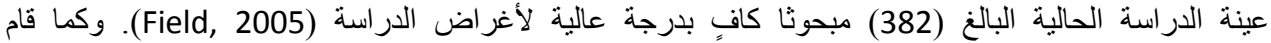

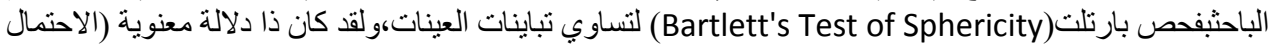

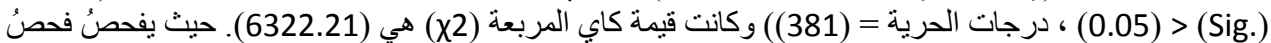

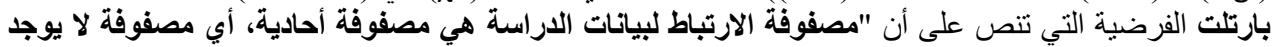

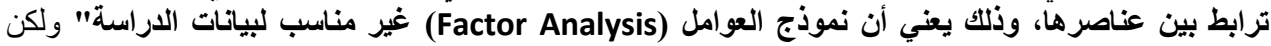

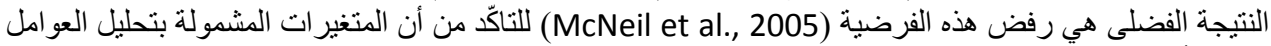

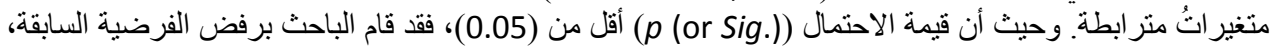

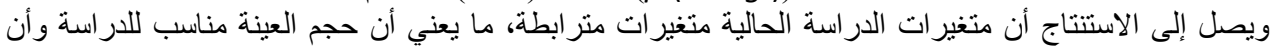

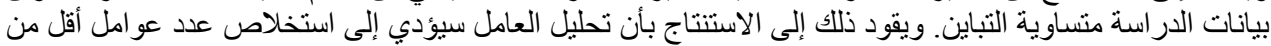

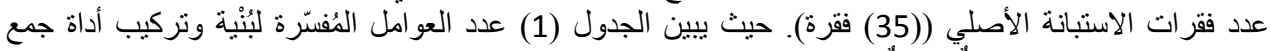

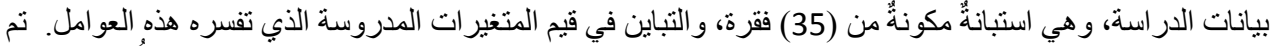

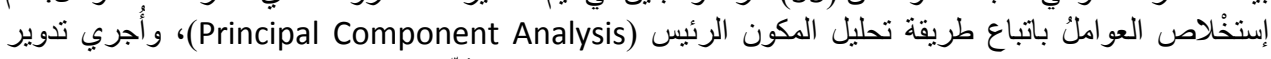

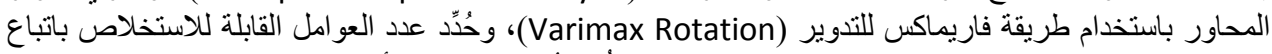

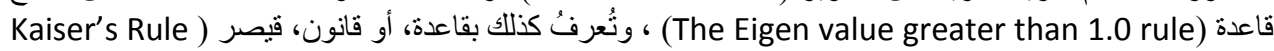
((Kaiser, 1960, 1974)

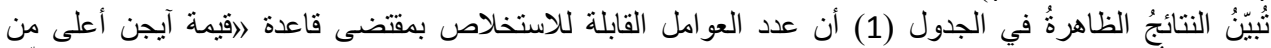

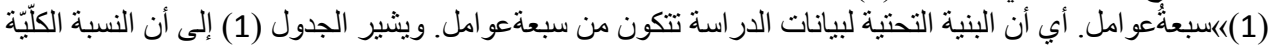

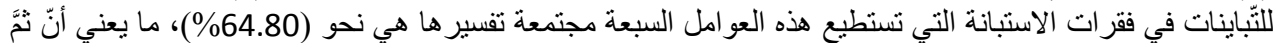

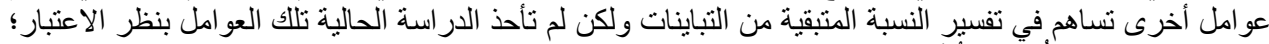

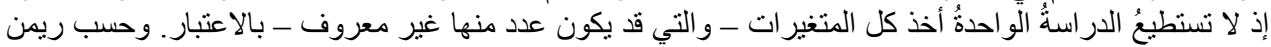

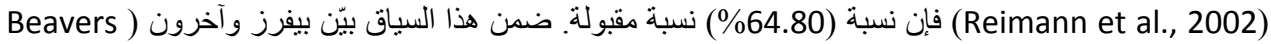

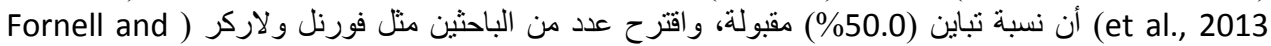

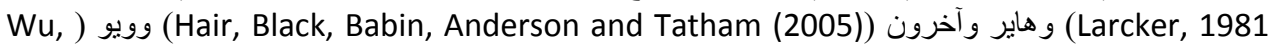

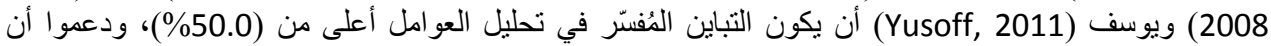

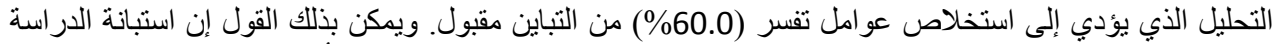

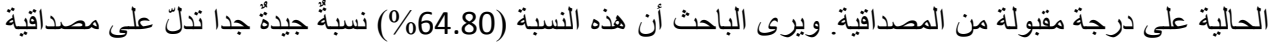
تقاربية أو تجميعية (Convergent Validity) عالية. 
The Influence of Organizational Justice on Job Commitment in the Jordanian Ministries

\begin{tabular}{|c|c|c|c|c|c|c|}
\hline \multicolumn{3}{|c|}{ مجاميع الارتباطات المربعة بعد التدوير } & \multicolumn{3}{|c|}{ قيم آيجن الابتدائية } & \multirow{2}{*}{ (العامل) } \\
\hline التباين التراكمي & التباين الفردي & قيمة آيجن 7 & التباين التراكمي 6 & التباين الفردي 5 & قيمة|آيجن 4 & \\
\hline 33.835 & 33.835 & 11.842 & 33.835 & 33.835 & 11.842 & 1 \\
\hline 42.805 & 8.970 & 3.140 & 42.805 & 8.970 & 3.140 & 2 \\
\hline 48.840 & 6.035 & 2.112 & 48.840 & 6.035 & 2.112 & 3 \\
\hline 54.162 & 5.321 & 1.863 & 54.162 & 5.321 & 1.863 & 4 \\
\hline 58.505 & 4.343 & 1.520 & 58.505 & 4.343 & 1.520 & 5 \\
\hline 61.704 & 3.199 & 1.120 & 61.704 & 3.199 & 1.120 & 6 \\
\hline \multirow[t]{28}{*}{64.805} & 3.101 & 1.085 & 64.805 & 3.101 & 1.085 & 7 \\
\hline & & & 67.635 & 2.830 & .990 & 8 \\
\hline & & & 70.134 & 2.499 & .875 & 9 \\
\hline & & & 72.386 & 2.253 & .788 & 10 \\
\hline & & & 74.485 & 2.098 & .734 & 11 \\
\hline & & & 76.406 & 1.921 & .672 & 12 \\
\hline & & & 78.316 & 1.910 & .668 & 13 \\
\hline & & & 79.974 & 1.658 & .580 & 14 \\
\hline & & & 81.545 & 1.571 & .550 & 15 \\
\hline & & & 83.021 & 1.476 & .517 & 16 \\
\hline & & & 84.458 & 1.437 & .503 & 17 \\
\hline & & & 85.796 & 1.338 & .468 & 18 \\
\hline & & & 87.104 & 1.308 & .458 & 19 \\
\hline & & & 88.298 & 1.193 & .418 & 20 \\
\hline & & & 89.457 & 1.160 & .406 & 21 \\
\hline & & & 90.609 & 1.151 & .403 & 22 \\
\hline & & & 91.667 & 1.058 & .370 & 23 \\
\hline & & & 92.618 & .952 & .333 & 24 \\
\hline & & & 93.536 & .917 & .321 & 25 \\
\hline & & & 94.393 & .858 & .300 & 26 \\
\hline & & & 95.195 & .801 & .280 & 27 \\
\hline & & & 95.964 & .769 & .269 & 28 \\
\hline & & & 96.644 & .680 & .238 & 29 \\
\hline & & & 97.304 & .660 & .231 & 30 \\
\hline & & & 97.944 & .639 & .224 & 31 \\
\hline & & & 98.531 & .588 & .206 & 32 \\
\hline & & & 99.055 & .524 & .183 & 33 \\
\hline & & & 99.564 & .508 & .178 & 34 \\
\hline
\end{tabular}


Journal of Social Sciences (COES\&RJ-JSS), 8(2), pp.230-269

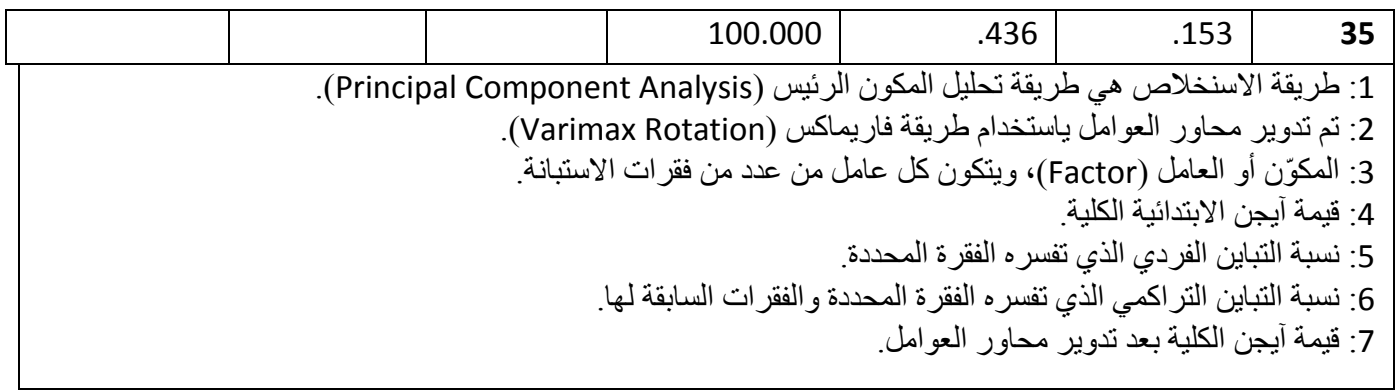

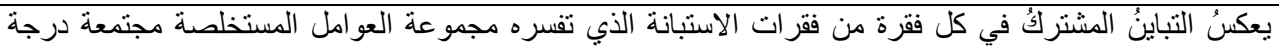

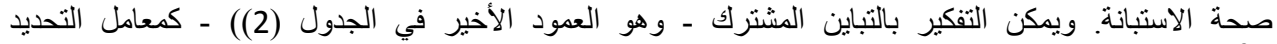

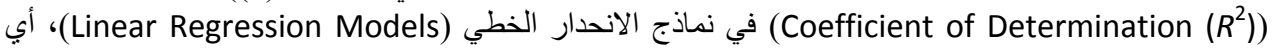

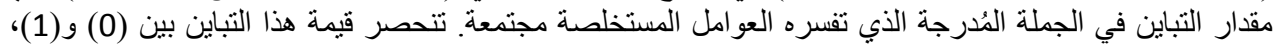

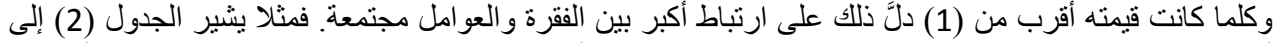

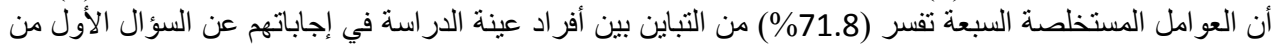

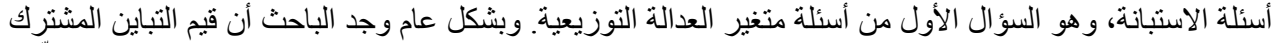

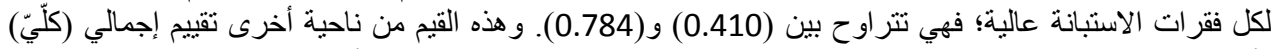

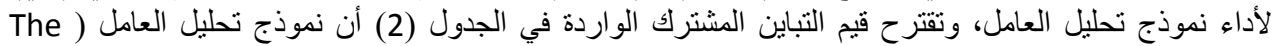
(Factor Analysis Model

جلدول (2): التباين في كل فقرة الذي تفسره العو امل مجتمعة عالية من الصحة و المصداقية.

\begin{tabular}{|c|c|c|c|}
\hline التباين المشترك & الفقرة & |المتغير & رقم الفقرة \\
\hline 0.718 & يتناسب دخلي مع ما أقوم به من جهد داخل المنظمة. & العدالة التوزيعية & 1 \\
\hline 0.572 & أحصل. على مكافأة عادلة مقابل الإنجازاتالإضافية التي أبذلها في & & 2 \\
\hline 0.559 & يتم توزيع المهام و الواجبات الوظيفية بين الموظفين بطريقة عادلة. & & 3 \\
\hline 0.569 & يتناسب دخلي الثهري مع مؤهلي العلمي و خبرتي في العمل. & & 4 \\
\hline 0.410 & المبذاتلة دخلي مع دخل زملاء العمل الذين يماثلتونني بالوظيفة و الجهود & & 5 \\
\hline 0.685 & يتم تطبيق القرارات الإدارية على الجميع بدون استثناء. & عدالة الإجراعات & 1 \\
\hline 0.701 & يتم اتخاذ القرار ات على مبدأ عدم التحيز لأي شخص. & & 2 \\
\hline 0.627 & يحرص المدير على استشارة الموظفين قبل عملية اتخاذ القرارات. & & 3 \\
\hline 0.643 & ينم اتخاذ القرارات على أسس موضوعية فيما يتعلق بعملي. & & 4 \\
\hline 0.617 & يتم اتخاذ إجر اءات تأدييية على كل من يسيء بدون محاباة. & & 5 \\
\hline 0.608 & تتم معاملتي باحتر ام من قبل المشرفين أو المدر اء. & العدالة الشخصية & 1 \\
\hline 0.506 & مشترفي. إعطائي ملاحظات أو نعليقات غير لائقة من قبل مديري أو & & 2 \\
\hline 0.640 & 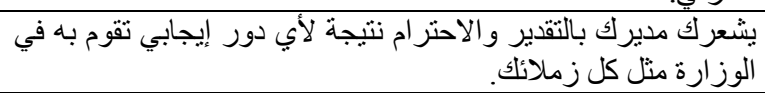 & & 3 \\
\hline 0.703 & بالتعامل يتم اتخاذ القرارات حول وظيفتي يقوم مشرفي أو مديري & & 4 \\
\hline 0.592 & عندمايتماتخاذّا القرار اتحولوظيفتي يظهر المدير قلقَابشأنحقيكموظف. & & 5 \\
\hline 0.695 & تشجع الإدارة على تبادل المعلومات حول خدماتتا المقدمة للمر اجعين. & عدالة المعلومات & 1 \\
\hline 0.745 & بطريقة توثيق البيانات و والمعلومات المتعلقة بالعمل ونشرها وتعميمها & & 2 \\
\hline 0.732 & يتم اطلاعي على طبيعة القزارات المتعلقة بعملي. & & 3 \\
\hline 0.708 & توزع وتنشر المعلومات بعدالة بين العاملين. & & 4 \\
\hline 0.631 & يوضحمديري أو مشرفي بوضوح أي قرار يتخذ بشأن وظيفتي. & & 5 \\
\hline
\end{tabular}


The Influence of Organizational Justice on Job Commitment in the Jordanian Ministries

\begin{tabular}{|c|c|c|c|}
\hline 0.511 & أشُعر بأنني أعمل في جو عائلي في الوزارة التي أعمل بها. & \multirow[t]{5}{*}{ الالتزام العاطفي } & 1 \\
\hline 0.627 & أرى أن قيمي الثخصية تتفق مع قيم الوزارة. & & 2 \\
\hline 0.684 & 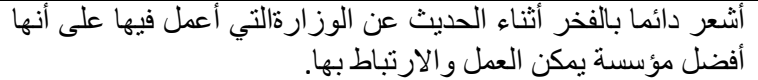 & & 3 \\
\hline 0.711 & أشتعر بالر غبة في بذل مجهود كبير لتحقيق أهداف الوزارة. & & 4 \\
\hline 0.731 & أشعر بانتماء قوي للوزارة التي أعمل بها. & & 5 \\
\hline 0.657 & أقفبل أب عمل أكلف به من قبل الإدارة حتى أضمن استمر ارية العمل. & \multirow{5}{*}{ الاستمراري } & 1 \\
\hline 0.599 & 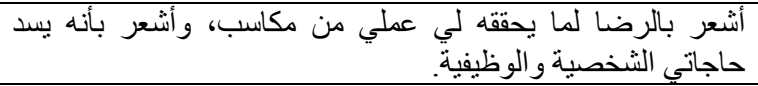 & & 2 \\
\hline 0.777 & بقائي في آلعمل هو فقط خوفي من قلة البدائل إذا أردت أن أبحث عن & & 3 \\
\hline 0.784 & إن بقائي في المنظمة حاليا هو الحاجة لمصدر دخل وليس رغبة & & 4 \\
\hline 0.629 & الآنقالي إلى مكانتي الحالية. & & 5 \\
\hline 0.624 & أشُعر أنَه من الو اجب علي البقاء في عملي في الوزارة. & \multirow[t]{5}{*}{ الالتزام المعياري } & 1 \\
\hline 0.585 & بقائي في المنظمة التي أعمل بها ينبع من الالتز ام الأخلاقي لها. & & 2 \\
\hline 0.688 & ترك منظمتي. على عرض عمل آخر أفضل أشعر أنه ليس من الأخلاقي & & 3 \\
\hline 0.650 & نفسي. بالامتنان لما تقدمه الوزارة لي من فرص وامتيازات لنطوير & & 4 \\
\hline 0.764 & سوفَ أُشعر بالذنب إذا قمت بترك العمل في الوزارة. & & 5 \\
\hline
\end{tabular}

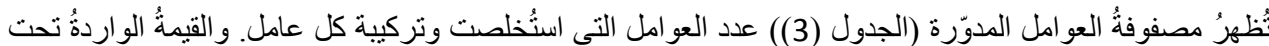

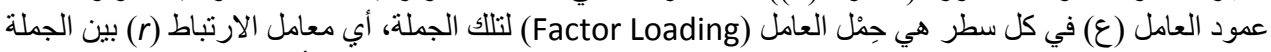

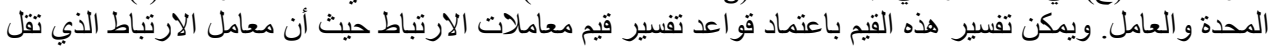

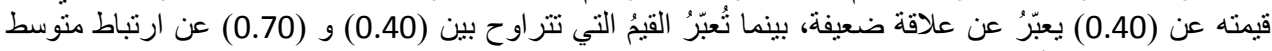

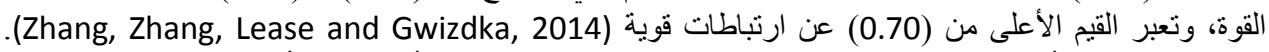

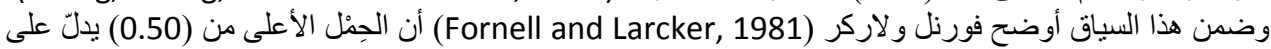

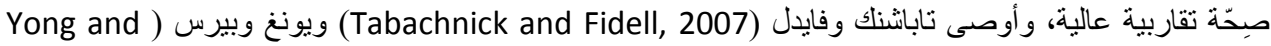

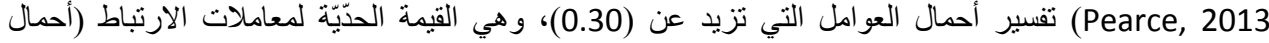

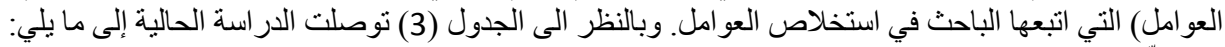

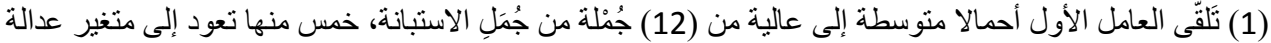

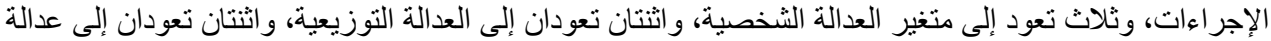

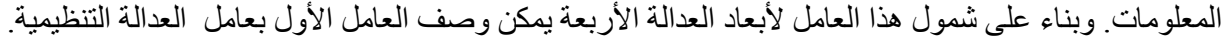
جدول (3): مصفوفة العو امل المدوّرة

\begin{tabular}{|c|c|c|c|c|c|c|c|c|}
\hline \multicolumn{6}{|c|}{ العامل (ع) } & \multirow{2}{*}{ الجمثة } & \multirow[t]{2}{*}{ المتغير } & \multirow[t]{2}{*}{ الجملة } \\
\hline 6 & 5 & 4 & 3 & 2 & 1 & & & \\
\hline & & & & & 0.773 & 1 & الإجراءات & استثناء. تطبيق القرارات الإدارية على الجميع بدون \\
\hline & & & & & 0.768 & 2 & الإجراءات & شتخص اتخاذ القرارات على مبدأ عدم التحيز لأي \\
\hline & & & & & 0.756 & 3 & الإجراءات & اتخاذ القرار المدير على استشارة الموظفين قبل عملية \\
\hline & & & & & 0.748 & 4 & الإجراءات & يتعلق بعملي. القرار ات على أسس موضو عية فيما \\
\hline
\end{tabular}


Journal of Social Sciences (COES\&RJ-JSS), 8(2), pp.230-269

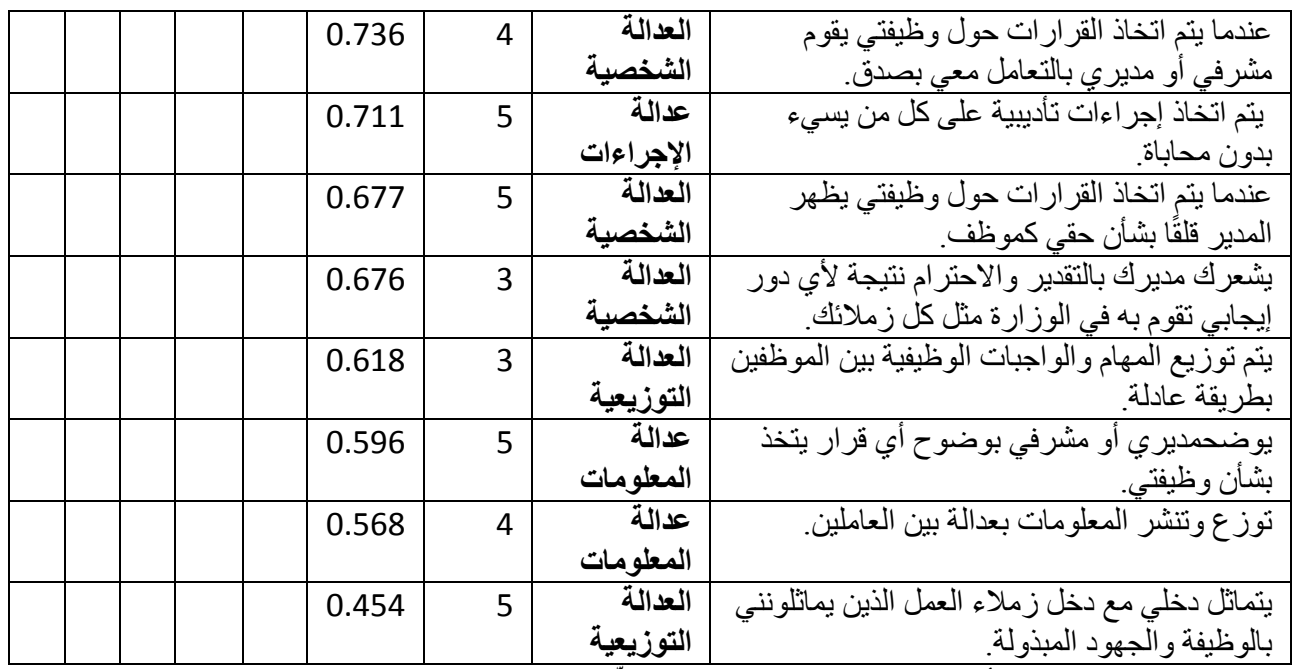

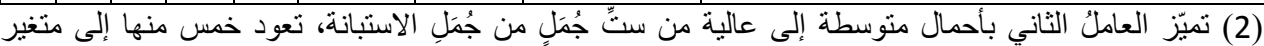

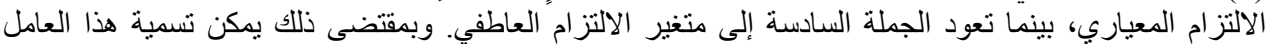

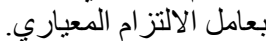

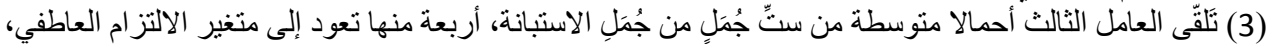
وتعود اثتتان منها إلى متغير العدالة الثخصية، ولذلك يمكن تسمية هذا العامل بعامل الالتز ام العاطفي.

جدول (3): مصفوفة العوامل المدوّرة (تتمّة)

\begin{tabular}{|c|c|c|c|c|c|c|c|c|}
\hline \multicolumn{6}{|c|}{ العامل (ع) } & \multirow{2}{*}{ رقمثمة } & \multirow[t]{2}{*}{ المتغير } & \multirow[t]{2}{*}{ الجملة } \\
\hline 6 & 5 & 4 & 3 & 2 & 1 & & & \\
\hline & & & & 0.819 & & 3 & المياري & 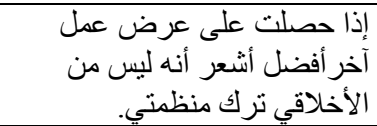 \\
\hline & & & & 0.810 & & 5 & المعياري & العمل في الوزعر بالذنب إذا قمت بترك \\
\hline & & & & 0.724 & & 4 & المعياري & لي من فرصامتنان لما تقدمه الوزارة لنطوير \\
\hline & & & & 0.698 & & 1 & المياري & في عملي في الوزارة. أنه من الواجب علي البقاء \\
\hline & & & & 0.659 & & 2 & المعياري & يقبع من الالتنز ام الأخلاّفي لها. الهمل بها \\
\hline & & & & 0.514 & & 3 & الالتزفي & 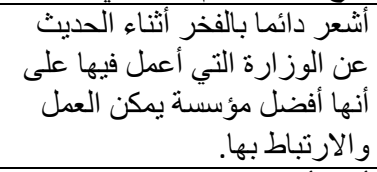 \\
\hline & & & 0.594 & & & 2 & الالتزفي & قأرى أن قيمي الثخصية تتفق مع \\
\hline & & & 0.592 & & & 1 & الثخالة & تتشم معاملتي باحتر ام من قبل \\
\hline & & & 0.584 & & & 2 & الثخالة & يتير إعطائي ملاحظة منيل منيري أو تعليقات \\
\hline
\end{tabular}


The Influence of Organizational Justice on Job Commitment in the Jordanian Ministries

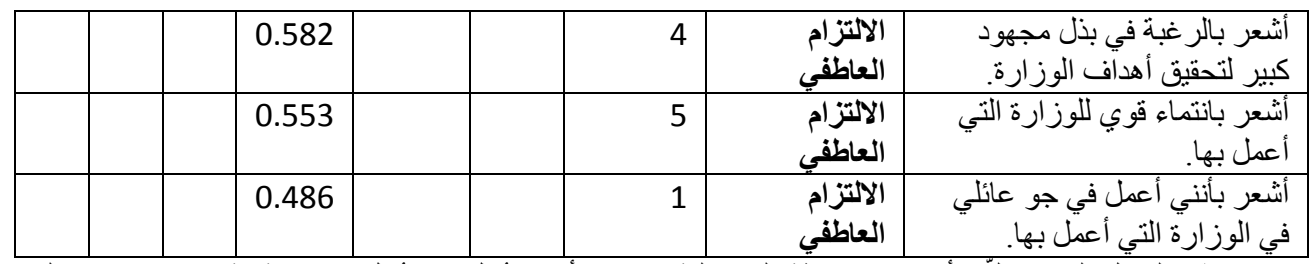

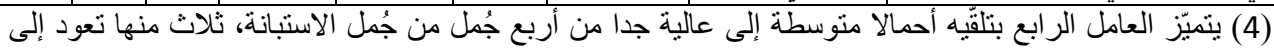

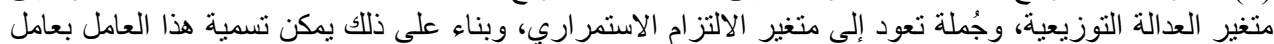

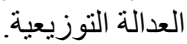

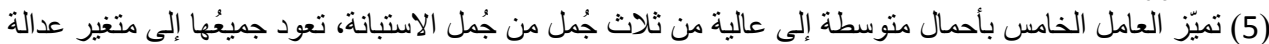

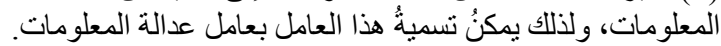
(6) تلقّى العامل السادل أحمالا عالية من ثلاث جمل فقط تعود إلى اللى متغير الالتزام الاستمراري، ولهذا السبب يمكن جدول (3): مصفوفة العوامل المدوّرة (تتمّة)

\begin{tabular}{|c|c|c|c|c|c|c|c|c|}
\hline \multicolumn{6}{|c|}{ العامل (ع) } & \multirow{2}{*}{ الجملة } & \multirow[t]{2}{*}{ المتغير } & \multirow[t]{2}{*}{ الجملة } \\
\hline 6 & 5 & 4 & 3 & 2 & 1 & & & \\
\hline & & 0.827 & & & & 1 & العدالة التوزيعية & يتهاسب داخل دخلي مع ما أقوم به من. \\
\hline & & 0.719 & & & & 4 & العدالة التوزيعية & العلمي و خبرتي في التعمل. مؤهلي \\
\hline & & 0.673 & & & & 2 & العدالة التوزيعية & 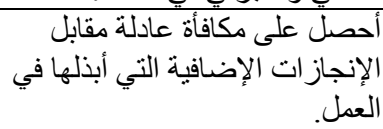 \\
\hline & & 0.454 & & & & 2 & الالتزام الاستمراري & 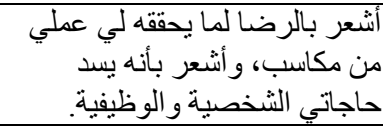 \\
\hline & 0.734 & & & & & 2 & عدالة المعلومات & 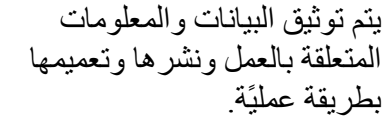 \\
\hline & 0.638 & & & & & 1 & عدالة المعلومات & 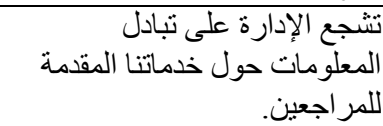 \\
\hline & 0.620 & & & & & 3 & عدالة المعلومات & التتعلقة بعملي. على طبيعة القرارات \\
\hline .835 & & & & & & 4 & الالتزام الاستمراري & إلناجة لَّصدي في المنظمة دخل حاليا هو رغبة \\
\hline .809 & & & & & & 3 & الالتزام الاستمراري & 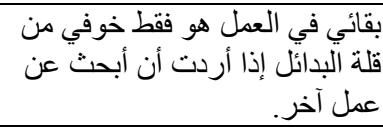 \\
\hline .697 & & & & & & 5 & الالتزام الاستمراري & 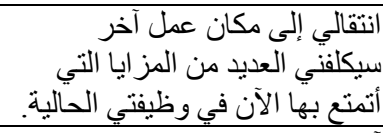 \\
\hline
\end{tabular}

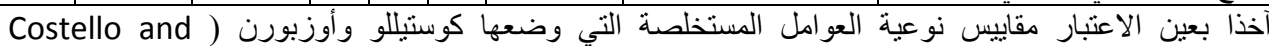

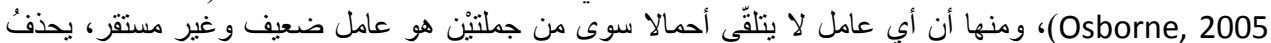

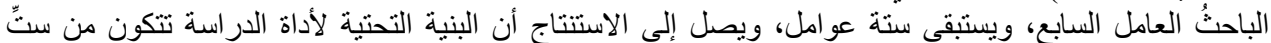

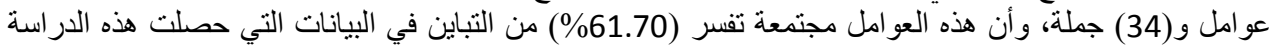

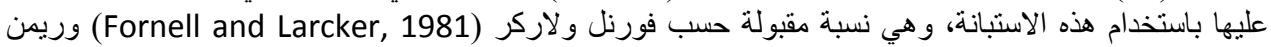




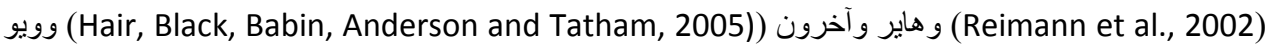

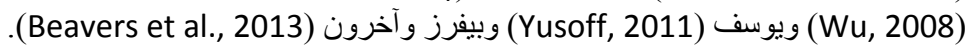

3.6.3 ثبات أداة الدراسة (Reliability)

بهدف التحقق من مناسبة استبانة الدراسة لأغراض اضل ولمجتمع الدراسة، فحص الباحث ثبات الاستبانة مستخدما فحص

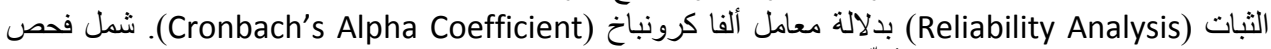

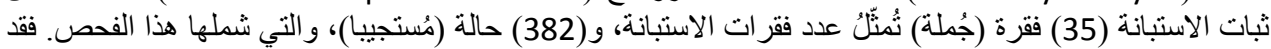

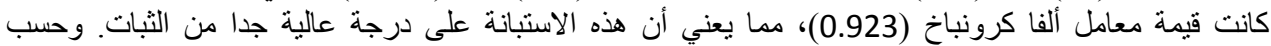

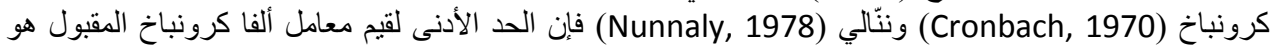

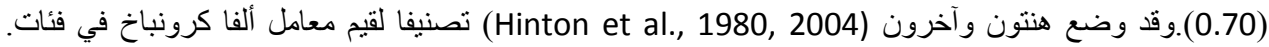

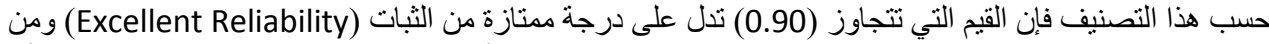

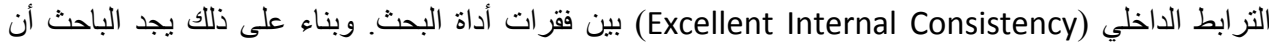

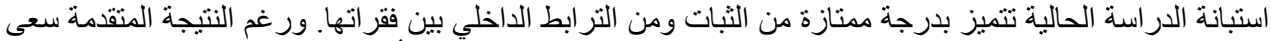

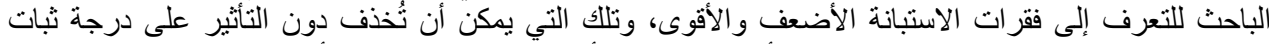

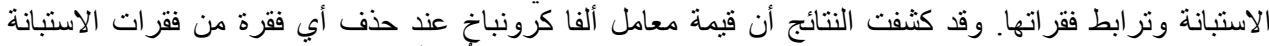

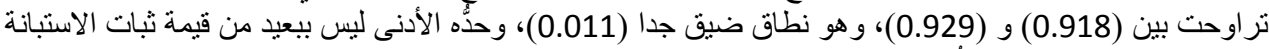

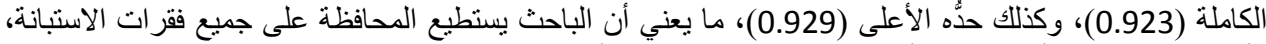

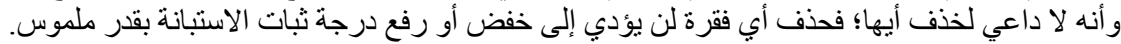

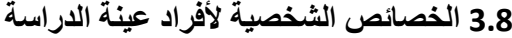
أجرى الباحث تحليل التوزيع التكر اري (Frequency Distribution Analysis) بهدف التعرف التهرف إلى أهم الخصائص الثخصية (Demographic Characteristics) لأفراد عينة الدراسة، ويعرض الباحث في الفقرات التي تلي التي الجدول أهم النتائج.

الجدول (4): الخصائص الثخصية لأفراد عينة الدراسة

\begin{tabular}{|c|c|c|c|}
\hline النسبة المئوية الصحيحة & التكرار & الفئات & الخاصيّيّة \\
\hline 34.6 & 132 & وزارة التربية والتعليم & \multirow[t]{4}{*}{ الوزارة } \\
\hline 32.5 & 124 & وزارة الصحة & \\
\hline 33.0 & 126 & وزارة الأوقاف & \\
\hline 100.0 & 382 & المجموع & \\
\hline 62.0 & 237 & ذكر & \multirow[t]{4}{*}{ الجنس } \\
\hline 37.7 & 144 & انثى & \\
\hline 0.3 & 1 & قيمة ناقصة & \\
\hline 100.0 & 382 & المجموع & \\
\hline 29.3 & 112 & دبلوم فما دون & \multirow[t]{5}{*}{ المؤهل الاراسي } \\
\hline 49.2 & 188 & بكالوريوس & \\
\hline 20.9 & 80 & دراسات عليا & \\
\hline 0.5 & 2 & قيمة ناقصة & \\
\hline 100.0 & 382 & المجموع & \\
\hline 1.6 & 6 & أقل من 24 سنة & \multirow[t]{4}{*}{ الفئة العمرية } \\
\hline 21.7 & 83 & من 24 الى أقلّ من 34 & \\
\hline 40.6 & 155 & من 35 الى أقل من 45 & \\
\hline 33.2 & 127 & من 46 الى أقل من 56 & \\
\hline
\end{tabular}


The Influence of Organizational Justice on Job Commitment in the Jordanian Ministries

\begin{tabular}{|c|c|c|c|}
\hline 2.9 & 11 & 56 سنة فأكثر & \\
\hline 100.0 & 382 & المجموع & \\
\hline 9.2 & 35 & أقل من 5 سنوات & \multirow[t]{7}{*}{ الخبرة العملية } \\
\hline 22.3 & 85 & من 5 الى 10 سنوات او أقلّ & \\
\hline 27.8 & 106 & من 10 الى 15 سنة او أقل & \\
\hline 21.0 & 80 & من 15 الى 20 سنة أو أقلّ & \\
\hline 19.7 & 75 & 20 سنة فأكثر & \\
\hline .03 & 1 & قيمة ناقصة & \\
\hline 100.0 & 382 & المجموع & \\
\hline
\end{tabular}

كثف التحليل (الجدول 4) عن أن أعداد أفراد عينة الدراسة من موظفي الوزارات الثناث المدروسة (وزارة التربية

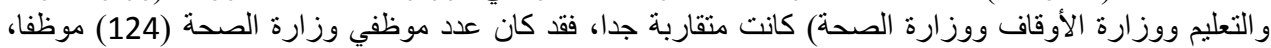

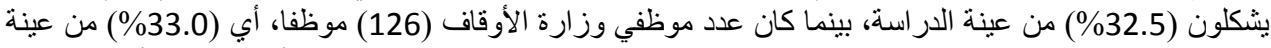

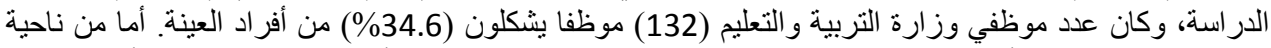

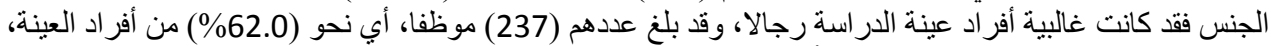

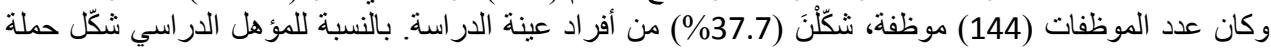

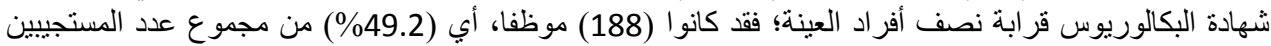

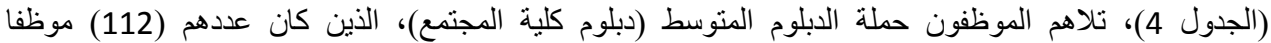

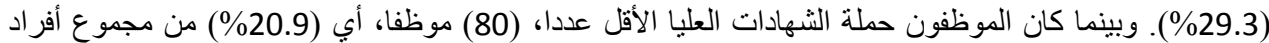

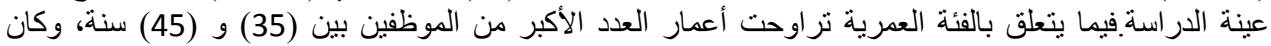

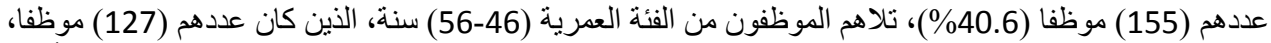

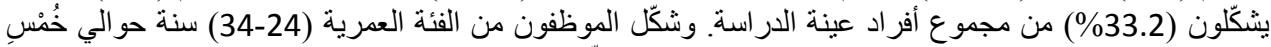

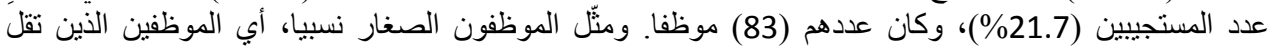

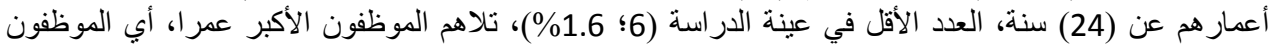

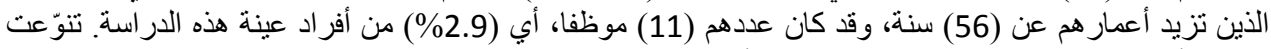

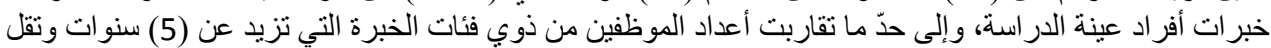

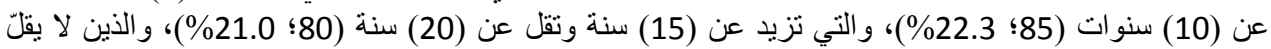

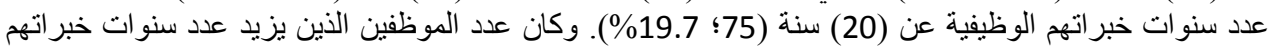

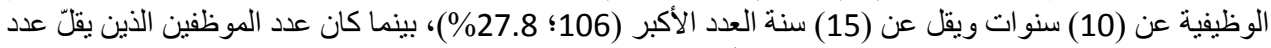
سنوات خبر اتهم الوظيفية عن (5) سنوات ونط عن العدد الأقل (35؛ 9.2\%). 3.9

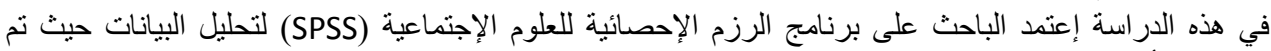
إستخدام الأدوات الإحصائية النالية: الإحصاء الوصفي (Descriptive Statistics Analysis) كالتكرارات والإنة والنسب المئوية و المتوسطات الحسابية و الأنحر افات المعيارية. تحليل التوزيع التكراري (Frequency Distribution Analysis) بهدف التعرف إلى أهم الخصائص الثخصية (Demographic Characteristics)

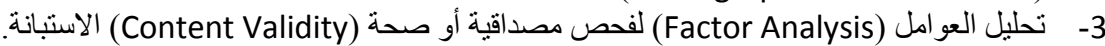

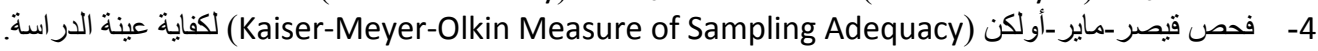
5- فحص بارتلت (Bartlett's Test of Sphericity) لتساوي تباينات العينات.

6- فص في نبات أداة الدراسة (Reliability Analysis) بدلالة معامل ألفا كرونباخ (Cronbach's Alpha . (Coefficient تحليل الاندار الخطّيّ البسيط (Coente Linear Regression Analysis). 
تحليل التباين (ANOVA- Analysis of variance) لمعرفة الفروقات ذات الدلالات الإحصائية بين متغيرات

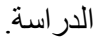
وـ نموذج الإنحدار المتعدد (StepwiseMethod) لبيان أثر العدالة التنظيمية بأبعادها في الإلتز ام الوظيفي بأبعاده. 3.10 معايير تصنيف المتوسطات الحسابية في إطار تصنيف الكنوسطات الحسابية فقد قسم الباحث فئات درجات موافية القاتة أفر اد عينة الدراسة على فقرات الإستبانة

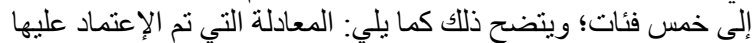
$\frac{5 \quad 1}{5}=0.80$

(الحد الأعلى - الحد الأدنى) / عدد الفئات(النعيمي، 2011) وبذلك تكون فترات ـ معايير - قيم المتوسطات الحسابية كالأتي:

\begin{tabular}{|c|c|}
\hline منخفض جذا & $1.80-1.0$ \\
\hline منخفض & $2.60-1.81$ \\
\hline متوسط & $3.40-2.61$ \\
\hline مرتفع & $4.20-3.41$ \\
\hline مرتفع جدا & $5.00-4.21$ \\
\hline
\end{tabular}

4.1 مستويات العدالّة التنظيمية والالتزام الوظيفي في الوزارات الأردنية المدروسة

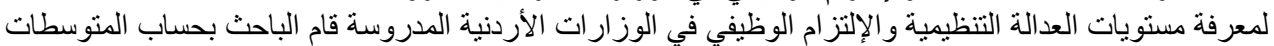

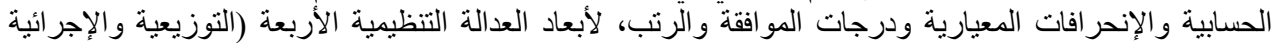

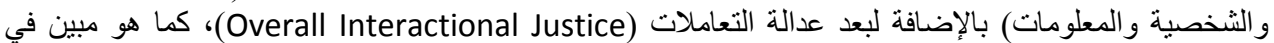

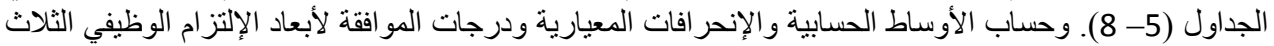

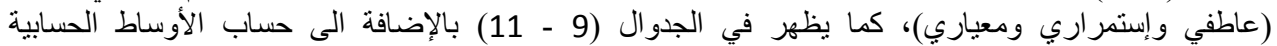

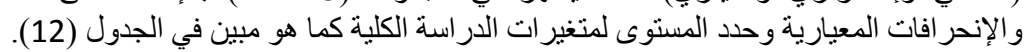

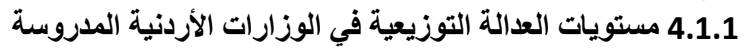

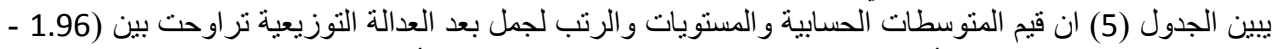

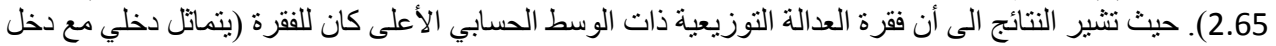

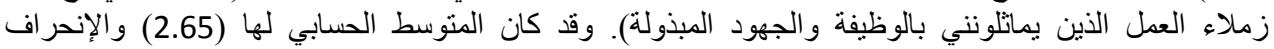

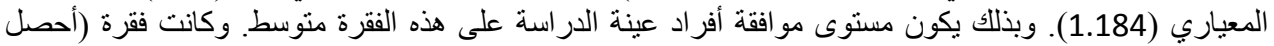

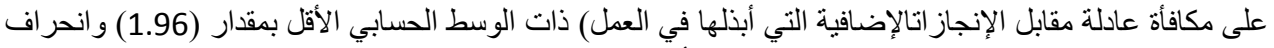

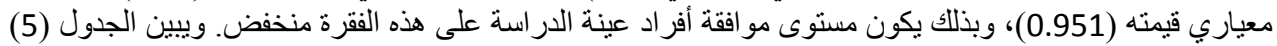

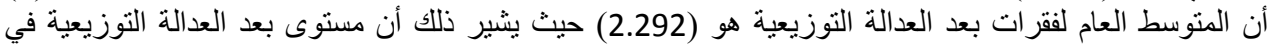

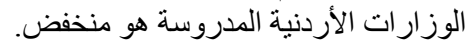
جدول (5): المتوسطات الحسابية والانحرافات المعيارية والمستويات والرتب لأستجابات أفراد عينة الدراسة لجمل بعد العدالة التوزيعية

\begin{tabular}{|c|c|c|c|c|c|}
\hline المرتبة & 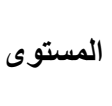 & المعياري & الحسابي & 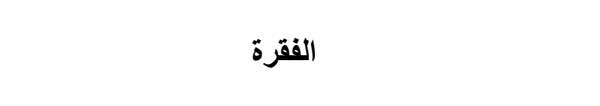 & رقفرة \\
\hline 1 & متو سط & 1.184 & 2.65 & يتماتل دخلى مع دخل زملاء العمل الذين يماتلو ننى & 1 \\
\hline 2 & منخفض & 1.029 & 2.56 & يتم توزيع المهام و الو اجبات الوظيفية بين الموظفين & 2 \\
\hline 3 & متوسط & 0.924 & 2.27 & يتتاسب دخلي مع ما أقوم به من جهد داخل المنظمة & 3 \\
\hline 4 & منخفض & 0.943 & 2.02 & يتناسب دخلي الشهري مع مؤهلي العلمي و خبرتي في & 4 \\
\hline 5 & 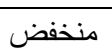 & 0.951 & 1.96 & أحصل على مكافأة عادلة مقابل الإنجاز اتالإضافية التي & 5 \\
\hline \multicolumn{3}{|c|}{ منخفض } & 2.292 & \multicolumn{2}{|l|}{ المتوسط الحسابي العام لبعد العدالة التوزيعية } \\
\hline
\end{tabular}

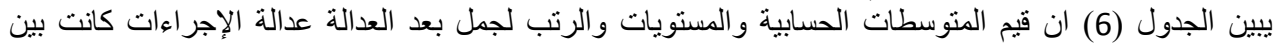
(2.51- 2.72). حيث أشارت النتائج الى أن فقرة عدالة الإجراء أتذات الوسط الحسابي الأعلى كان للفقرة (يتم اتخاذ الأن 
القرارات على أسس موضو عية فيما يتعلق بعملي)، وقد كان المتوسط الحسابي لها (2.72) و الإنحر اف المعياري

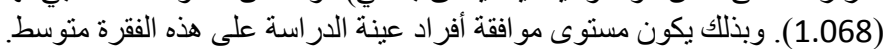

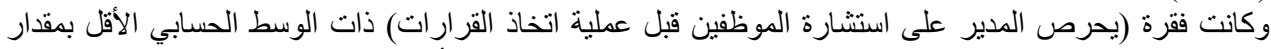

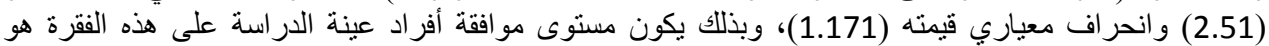

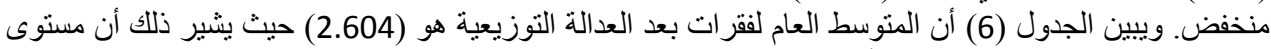

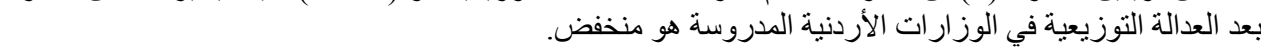
جدول (6): المتوسطات الحسابية والانحرافات المعيارية والمستويات والرتبة لألأستجابات أفراد عينة الدراسة لجمل بعد عدالة الإجراءات

\begin{tabular}{|c|c|c|c|c|c|}
\hline المرتبة & 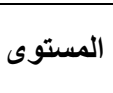 & 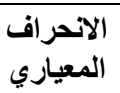 & 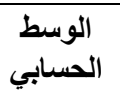 & الفقرة & الفقرة \\
\hline 1 & منوسط & 1.068 & 2.72 & يتم اتخاذ القرارات على أسس موضوعية فيما & 1 \\
\hline 2 & متوسط & 1.151 & 2.66 & يتم تطبيق القرارات الإدارية على الجميع بدون & 2 \\
\hline 3 & 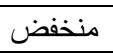 & 1.122 & 2.60 & يتم اتخاذ إجر اءات تأدييية على كل من يسيء & 3 \\
\hline 4 & منخفض & 1.132 & 2.53 & يتم اتخاذ القرارات على مبدأ عدم التحيز لأي & 4 \\
\hline 5 & منخفض & 1.171 & 2.51 & عملية اتخاذ القرير ارات على استشارة الموظفين قبل & 5 \\
\hline \multicolumn{3}{|c|}{ منخفض } & 2.604 & \multicolumn{2}{|l|}{ المتوسط الحسابي العام لبعد عدالة الإجراءات } \\
\hline
\end{tabular}

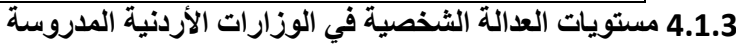

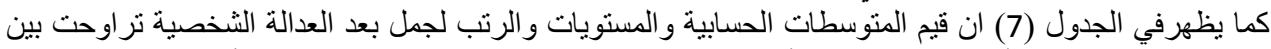

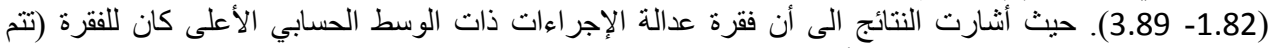

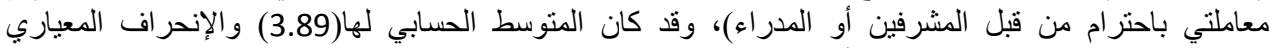

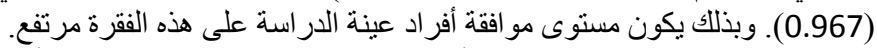

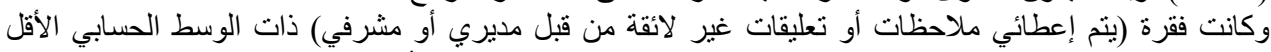

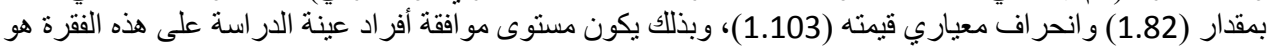

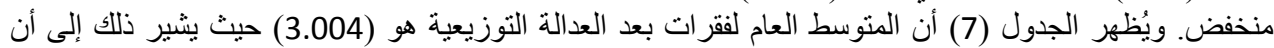

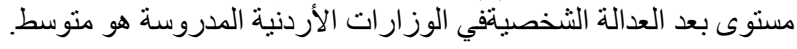

الجدول (7): المتوسطات الحسابية والانحرافات المعيارية والمستويات والرتب لأستجابات أفراد عينة الدراسة لجمل بعد العدالة الشخصية والبنية

\begin{tabular}{|c|c|c|c|c|c|}
\hline 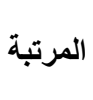 & 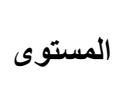 & 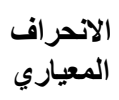 & 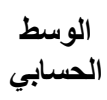 & 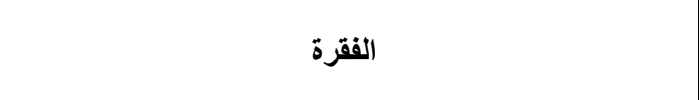 & 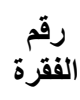 \\
\hline 1 & 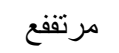 & 0.967 & 3.89 & تتم معاملتي باحتر ام من قبل المشرفين أو المدر اء & 1 \\
\hline 2 & 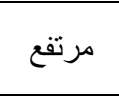 & 1.129 & 3.40 & بشه في الوز مديرك مثل كل زلتبر والاحتكر ام نتيجة لأي دور إيجابي تقوم & 2 \\
\hline 3 & متوسط & 1.138 & 3.18 & بالتعامل يتم اتخاذ القرار بصد حول وظيفتي يقوم مشرفي أو مديري & 3 \\
\hline 4 & منوسط & 1.148 & 2.73 & عندما يتم اتخاذ القرارات حول وظيفتي يظهر المدير قلقًا بشأن & 4 \\
\hline 5 & منخفض & 1.103 & 1.82 & يتم إعطائي ملاحظات أو تعليقات غير لائقة من قبل مديري أو & 5 \\
\hline \multicolumn{3}{|c|}{ متوسط } & 3.004 & \multicolumn{2}{|l|}{ المتوسط الحسابي العام لبعد العدالة الثخصية } \\
\hline
\end{tabular}

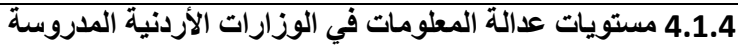

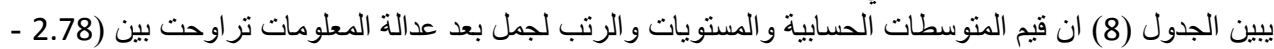

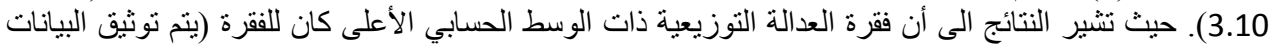

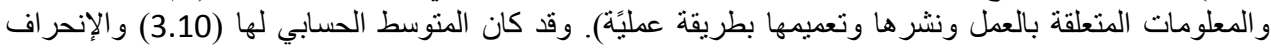
المعياري (150). وبذلك يكون مسنوى موافقة أفراد عينة الدراسة على هذه الفقرة متوسط. وكانت فقرة (توزع 


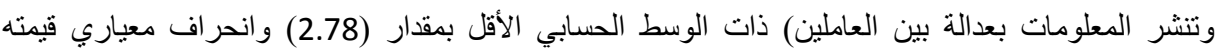

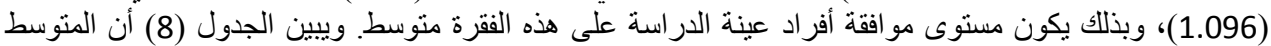

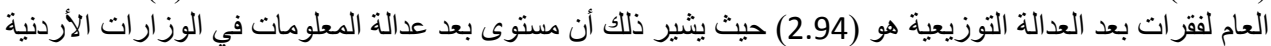
المدروسة هو متوسط. الجدول (8): المتوسطات الحسابية والاتحر افات المعيارية والمستويات والرتب لأستجابات أفراد عينة الدراسة لجمل بعد عدالة المعلومات والمبنوبات

\begin{tabular}{|c|c|c|c|c|c|}
\hline المرتبة & 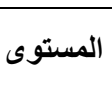 & المعياري & الحسابي & 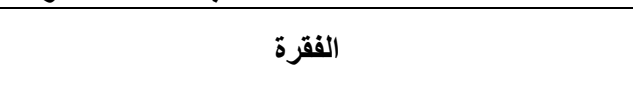 & رالفقرة \\
\hline 1 & متوسط & 1.150 & 3.10 & ويتم توثيق البيانات و المعلومات المتعلقة بالعمل ونشر ها & 1 \\
\hline 2 & متوسط & 1.107 & 2.98 & يوضح مديري أو مشرفي بوضوح أي قرار يتخذ بشأن & 2 \\
\hline 3 & متوسط & 1.101 & 2.96 & تشجع الإدارة على تبادل المعلومات حول خدماتنا المقدمة & 3 \\
\hline 4 & متوسط & 1.125 & 2.91 & يتم اطلاعي على طبيعة القرارات المتعلقة بعملي & 4 \\
\hline 5 & متوسط & 1.096 & 2.78 & توزع وتتشر المعلومات بعدالة بين العاملين & 5 \\
\hline \multicolumn{3}{|c|}{ متوسط } & 2.94 & \multicolumn{2}{|l|}{ المتوسط الحسابي العام لبعد عدالة المعلومات } \\
\hline
\end{tabular}

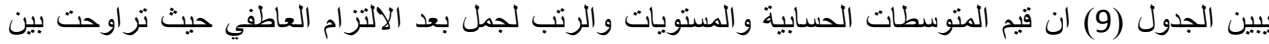

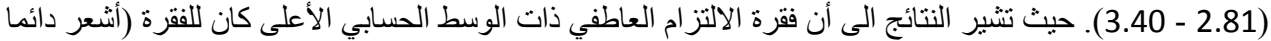

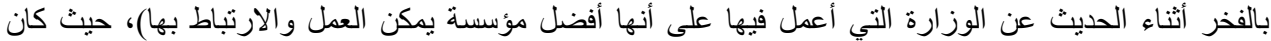

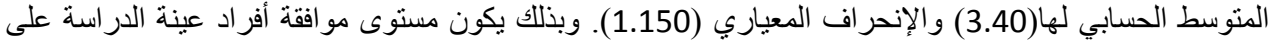

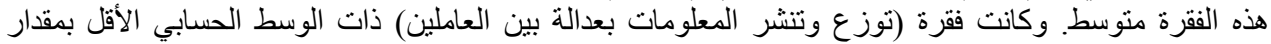

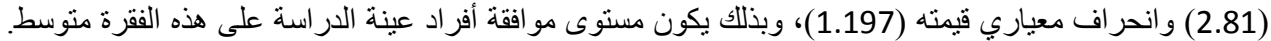

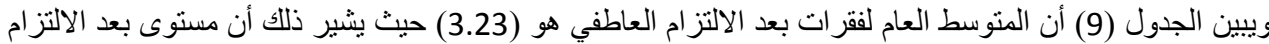
العاطفي في الوز ارات الأردنية المدروسة هو متوسط. الجدول (9): المتوسطات الحسابية والاتحرافات المعيارية والمستويات والرتب لأستجابات أفراد عينة الاراسة لجمل بعد الالتزام العاطفي والبنويات

\begin{tabular}{|c|c|c|c|c|c|}
\hline 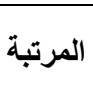 & 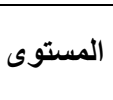 & المعياري & الحسابي & 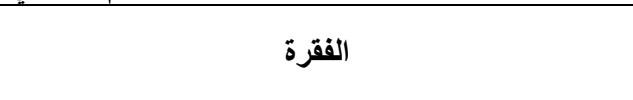 & رقفرة \\
\hline 4 & متوسط & 1.146 & 3.02 & أنشعر بأنني أعمل في جو عائلي في الوزارة التي أعمل & 1 \\
\hline 3 & متوسط & 1.146 & 3.07 & أرى أن قيمي الشخصية تتفق مع قيم الوزارة & 2 \\
\hline 5 & منوسط & 1.197 & 2.81 & أشعر دائما بالفخر أنثناء الحديث عن الوزارة التي أعمل & 3 \\
\hline 2 & منوسط & 1.174 & 3.38 & أشعر بالر غبة في بذل مجهود كبير لتحقيق أهداف الوزارة & 4 \\
\hline 1 & متوسط & 1.217 & 3.40 & أشعر بانتماء قوي للوزارة التي أعمل بها & 5 \\
\hline \multicolumn{3}{|c|}{ متوسط } & 3.23 & \multicolumn{2}{|l|}{ المتوسط الحسابي العام لبعد الالتزام العاطفي } \\
\hline
\end{tabular}

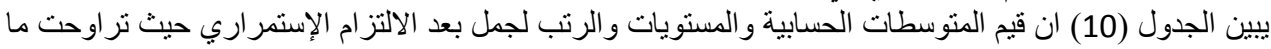

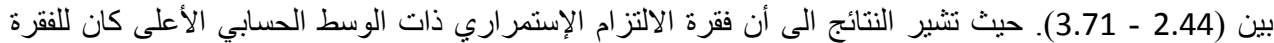

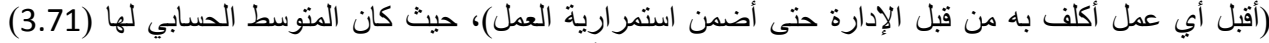

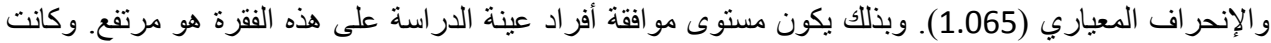

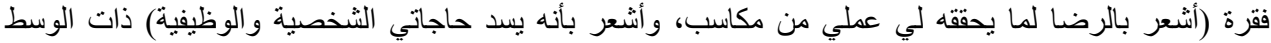

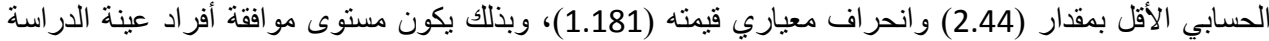

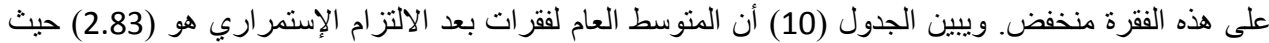
يشير ذلك أن مستوى بعد الالتزام الإستمر اري في الوزارات الأردنية الددروسة هو متوسط. 
The Influence of Organizational Justice on Job Commitment in the Jordanian Ministries

الجدول (10): المتوسطات الحسابية والاتحرافات المعيارية والمستويات والرتب لأستجابات أفراد عينة الدراسة

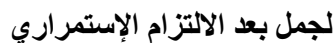

\begin{tabular}{|c|c|c|c|c|c|}
\hline المرتبة & 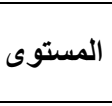 & المعياري & الحسبابي & 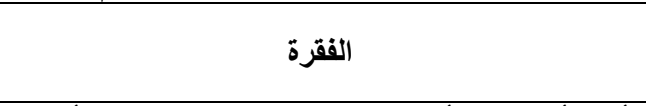 & الفقرة \\
\hline 1 & مرتفع & 1.065 & 3.71 & أقبل أبي عمل أكلف به من قبل الإدارة حتى أضمن & 1 \\
\hline 5 & 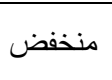 & 1.181 & 2.44 & 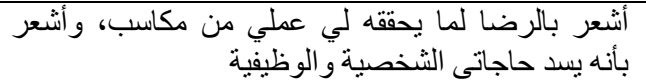 & 2 \\
\hline 2 & منوسط & 1.326 & 3.09 & بقائي في العمل هو فقط خوفي من قلة البدائل إذا أردت أن & 3 \\
\hline 3 & متوسط & 1.359 & 3.06 & إن بقائي في المنظمة حاليا هو الحاجة لمصدر دخل وليس & 4 \\
\hline 4 & متوسط & 1.065 & 2.79 & 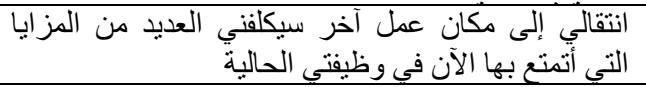 & 5 \\
\hline \multicolumn{3}{|c|}{ متوسط } & 2.83 & \multicolumn{2}{|l|}{ المتوسط الحسابي العام لبعد الالتزام الإستمراري } \\
\hline
\end{tabular}

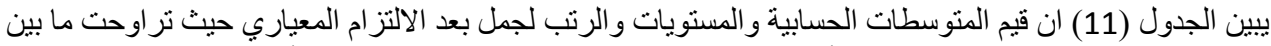

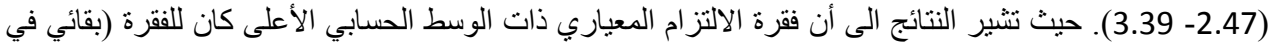

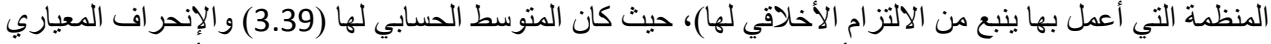

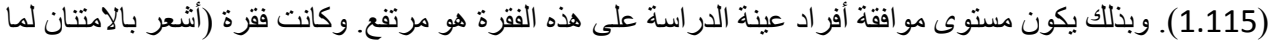

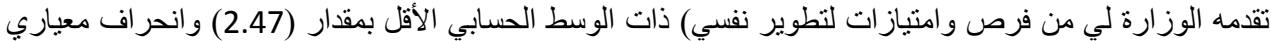

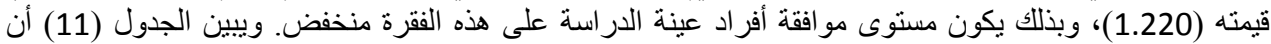

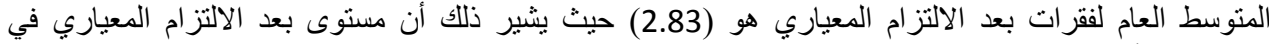
الوزارات الأردنية المدروسة هو منوسط.

الجدول (11): المتوسطات الحسابية والانحرافات المعيارية والمستويات والرتب لأستجابات أفراد عينة الدراسة ل الجمل بعد الالتزام المعياري والمبتويات

\begin{tabular}{|c|c|c|c|c|c|}
\hline المرتبة & 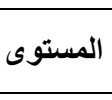 & 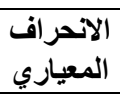 & الوسابي & 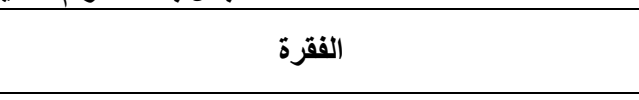 & الفقرة \\
\hline 2 & متوسط & 1.207 & 3.13 & أشتعر أنه من الواجب علي البقاء في عملي في الوزارة & 1 \\
\hline 1 & منوسط & 1.115 & 3.39 & اقبائي في المنظمة التي أعمل بها ينبع من الالتز ام الأخلافي & 2 \\
\hline 3 & متوسط & 1.307 & 2.66 & الإخا حصلافي ترك عنى عرضي عمل آخر أفضل أشعر أند ليس من & 3 \\
\hline 5 & 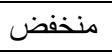 & 1.220 & 2.47 & أثشعر بالامتنان لما تقدهه الوزارة لي من فرص و امتياز ات & 4 \\
\hline 4 & منخفض & 1.317 & 2.50 & سوف أنشعر بالذنب إذا قمت بترك العمل في الوزارة & 5 \\
\hline \multicolumn{3}{|c|}{ متوسط } & 3.018 & \multicolumn{2}{|l|}{ المتوسط الحسابي العام لبعد الالتزام المعياري } \\
\hline
\end{tabular}

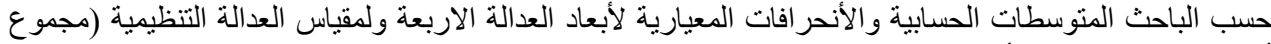

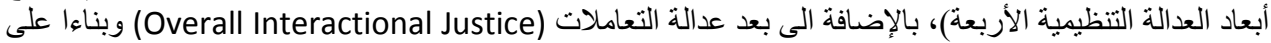

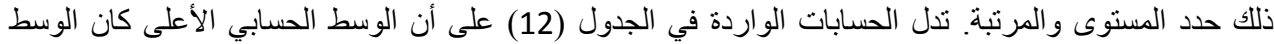

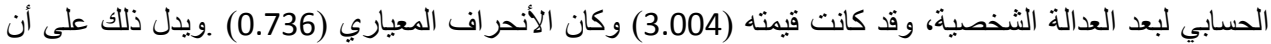

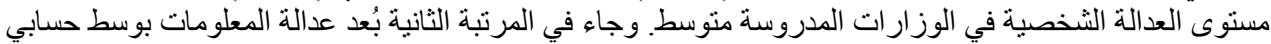

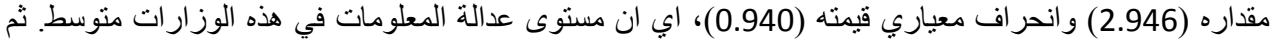

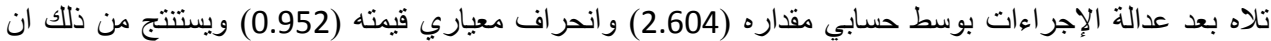

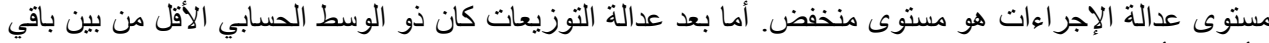

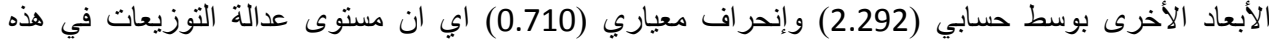
الوزارات هو منخفض. وبعد ذللك قام الباحث بحساب مستوى عدالة التعاملات (Overall Interactional Justice) و هي مجموع إفادات المبحوثين لبعدي عدالة المعلومات والعدالة الثخصية معا، حيث جاءت بمنوسط حسابي 


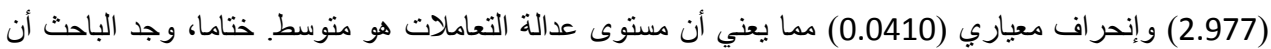

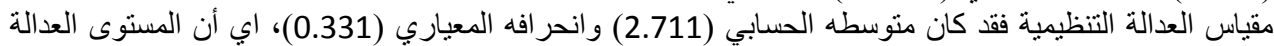

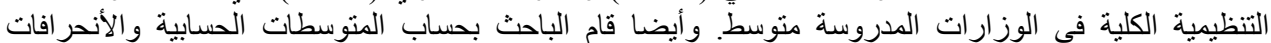

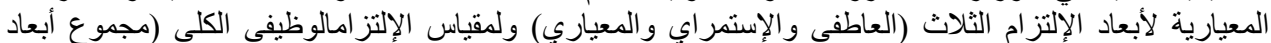

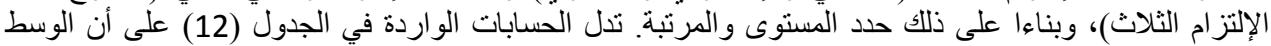

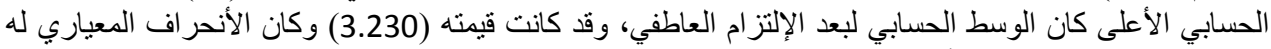

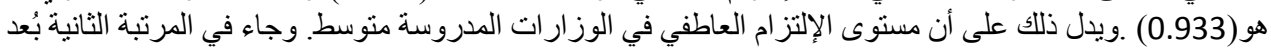

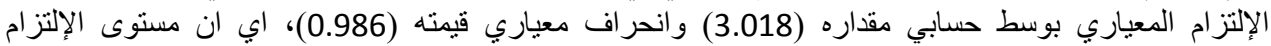

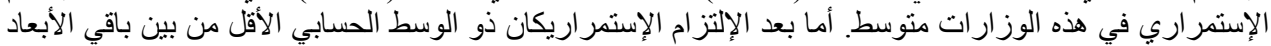

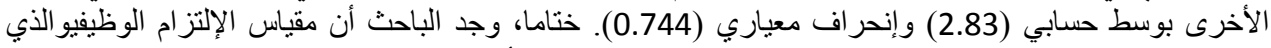

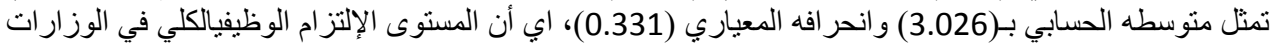
الجدروسة متوسط.

الجدول (12): المتوسطات الحسابية والانحرافات المعيارية والمستويات والرتب الكُلية لأبعاد متغيرات الدراسة

\begin{tabular}{|c|c|c|c|c|c|}
\hline \multicolumn{6}{|c|}{ المتغير المستقل (العدالة التظظيمية) } \\
\hline المرتبة & 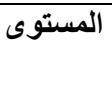 & المعياري & الحسابي & البعد & 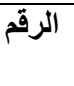 \\
\hline 4 & منخفض & 0.710 & 2.292 & العدالة التوزيعية & 1 \\
\hline 3 & منذفض & 0.952 & 2.604 & عدالة الإجراعات & 2 \\
\hline 1 & منوسط & 0.736 & 3.004 & العدالة الشخصية & 3 \\
\hline 2 & متوسط & 0.940 & 2.946 & عدالة المعلومات & 4 \\
\hline \multicolumn{2}{|c|}{ متوسط } & 0.331 & 2.711 & \multicolumn{2}{|l|}{ مقياس العدالة التنظيمية } \\
\hline \multicolumn{2}{|c|}{ متوسط } & 0.0410 & 2.977 & عدالة التعاملات (OverAll Interactional Justice) ع & - \\
\hline \multicolumn{6}{|c|}{ المتغير التابع (الألتزام الوظيفي) } \\
\hline 1 & متوسط & 0.933 & 3.230 & الإلتزام العاطفي & 1 \\
\hline 3 & متوسط & 0.744 & 2.830 & الإلتزام الإستمراري & 2 \\
\hline 2 & متوسط & 0.986 & 3.018 & الإلتزام المعياري & 3 \\
\hline \multicolumn{2}{|c|}{ متوسط } & 0.331 & 3.026 & \multicolumn{2}{|l|}{ 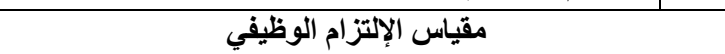 } \\
\hline
\end{tabular}

4.3

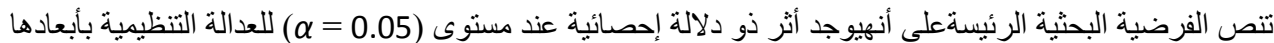

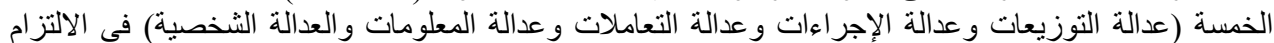

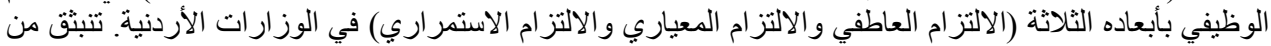

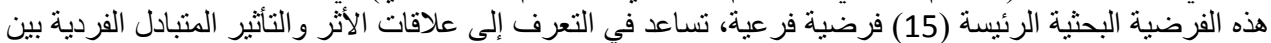

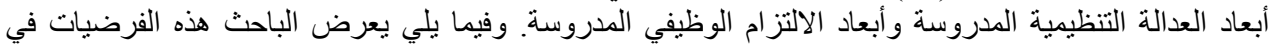

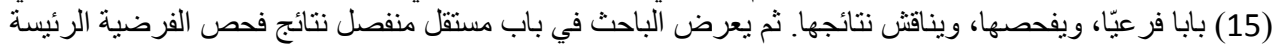

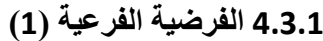

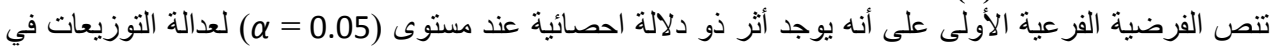

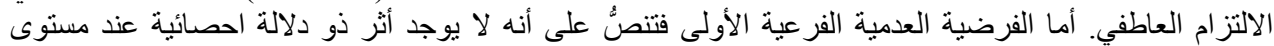
( )

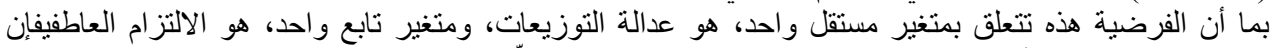

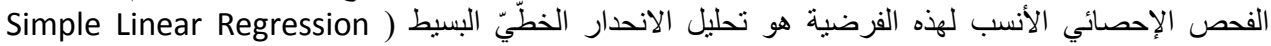

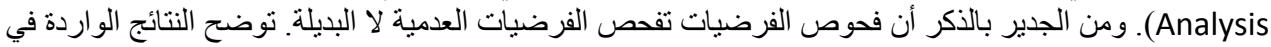

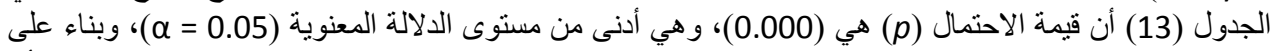

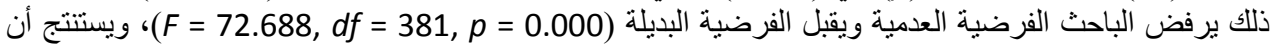


The Influence of Organizational Justice on Job Commitment in the Jordanian Ministries

هناك أثرا ذا دلالةإحصائية عند مستوى الدلالة (0.05) لعدالة التوزيعات في الالتزام العاطفي عند موظفي الوزارات

الجدول (13): تحليل التباين في نموذجة أثر عدالة التوزيعات في الالتزام العاطفي

الأردنية.

\begin{tabular}{|c|c|c|c|c|c|c|}
\hline لاحتمال & الدّالَ الإحصائي (F) & المربع & درجة الحرّيّة & جموع & & 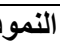 \\
\hline \multirow[t]{3}{*}{0.000} & 72.688 & 1326.012 & 1 & 1326.012 & الاتحدار & 1 \\
\hline & & 18.243 & 380 & 6932.187 & المتبقِيَ & \\
\hline & & & 381 & 8258.199 & الكَّيّ & \\
\hline
\end{tabular}

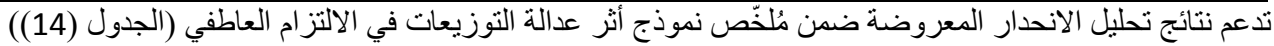

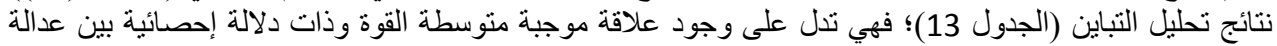

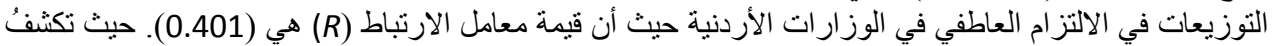

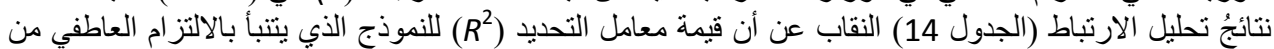

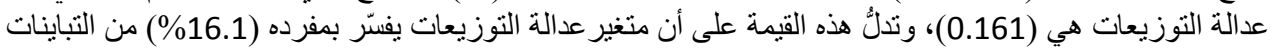

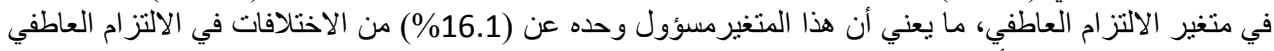
عند موظفي الوزارات الأردنية المدروسة.

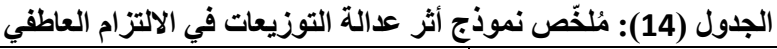

\begin{tabular}{|c|c|}
\hline 0.401 & معامل الارتباط (R) \\
\hline 0.161 & معامل التحديا (R2) \\
\hline 0.158 & معامل التحديد المعدل \\
\hline
\end{tabular}

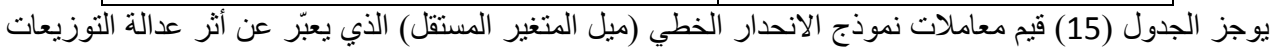

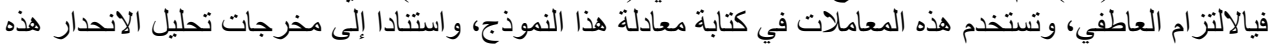

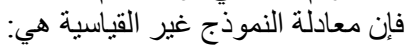
الالتزام العاطفي = 0.518 + 0.539 * عدالة التوزيعات

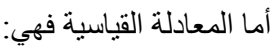
الالتز ام العاطفي = 0.401 * عدالة التوزيعات

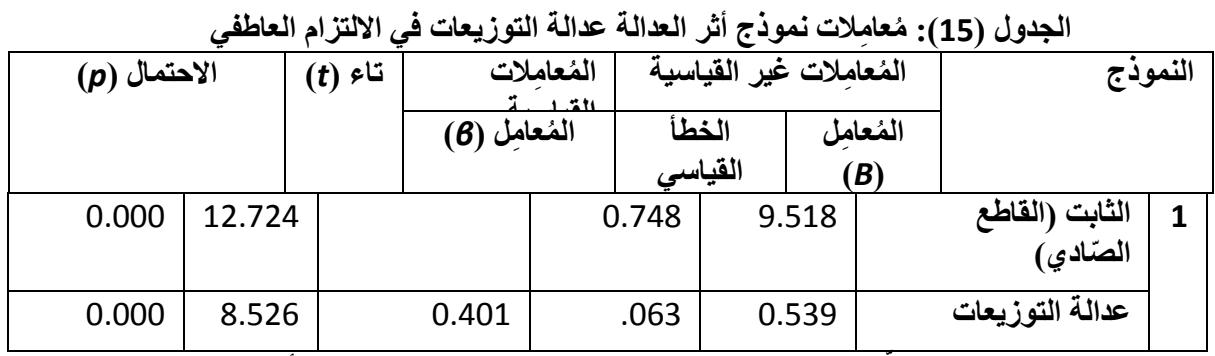

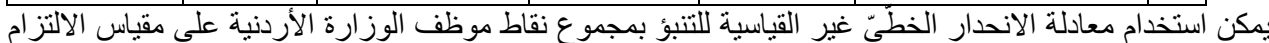

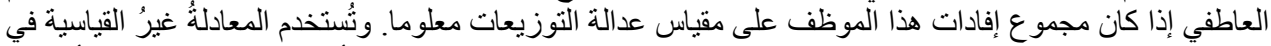

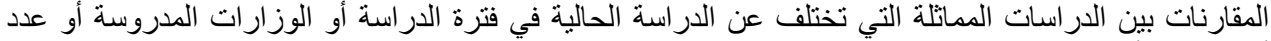

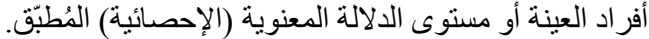

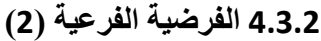

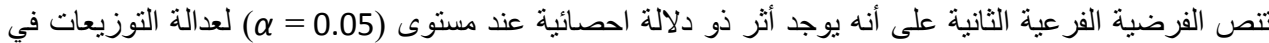

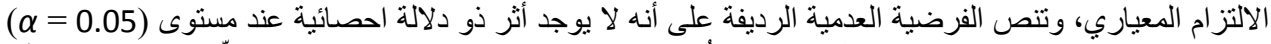

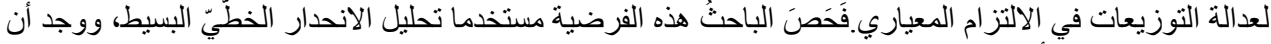

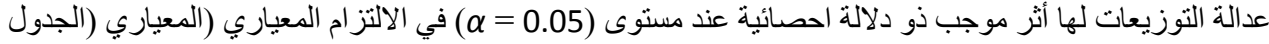

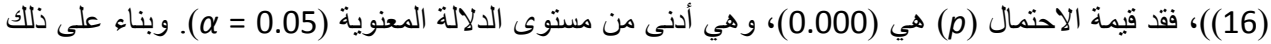

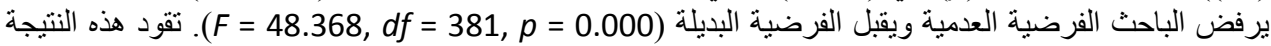

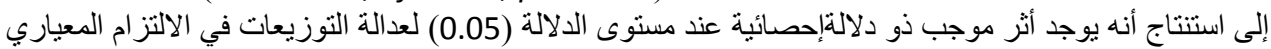

عند موظفي الوزارات الأردنية. 
Journal of Social Sciences (COES\&RJ-JSS), 8(2), pp.230-269

الجدول (16): تحليل التباين في نموذج أثر عدالة التوزيعات في الالتزام المعياري

\begin{tabular}{|c|c|c|c|c|c|c|}
\hline الاحتمال & الذاّلّ الإحصائي (F) & المربع المتوسط & درجة الحرّيّة & المربّعات & & النمو - النو \\
\hline \multirow[t]{3}{*}{0.000} & 48.368 & 1047.484 & 1 & 1047.484 & الانحدار & 1 \\
\hline & & 21.657 & 380 & 8229.534 & المتبقِي & \\
\hline & & & 381 & 9277.018 & الكَّيّ & \\
\hline
\end{tabular}

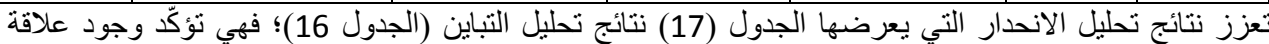

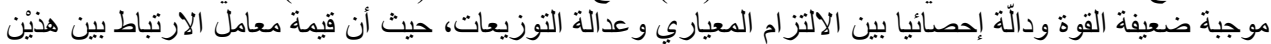

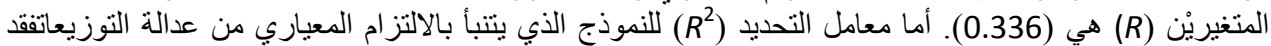

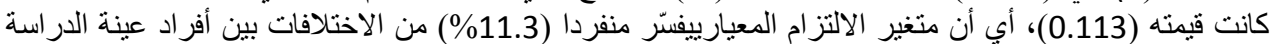
في متخير عدالة التوزيعاث.

الجدول (17): مُلخّص نموذج أثر عدالة التوزيعات في الالتزام المعياري

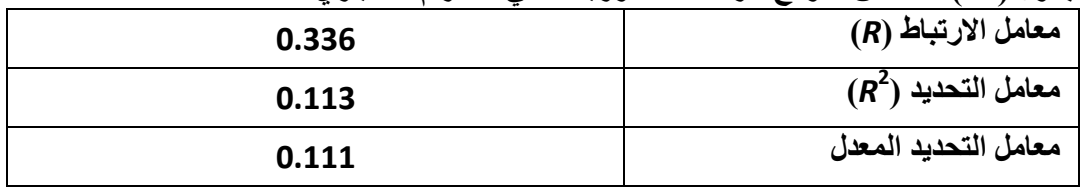

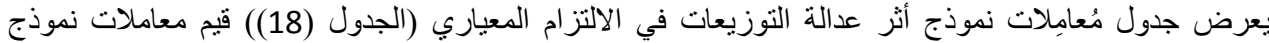

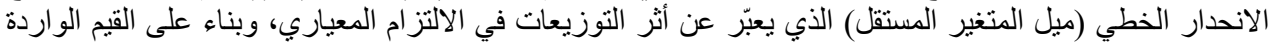
في هذا الجدول فإن معادلة النموذج غير القياسية هي: الإئي الالتز ام المعياري = 8.681 + 0.479 * عدالة التوزيعات

الالتز ام المعياري =0.336 * عدالة التوزيعات

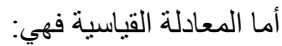

الجدول (18): مُعامِلات نموذج أثر عدالة التوزيعات في الالتزام المعياري

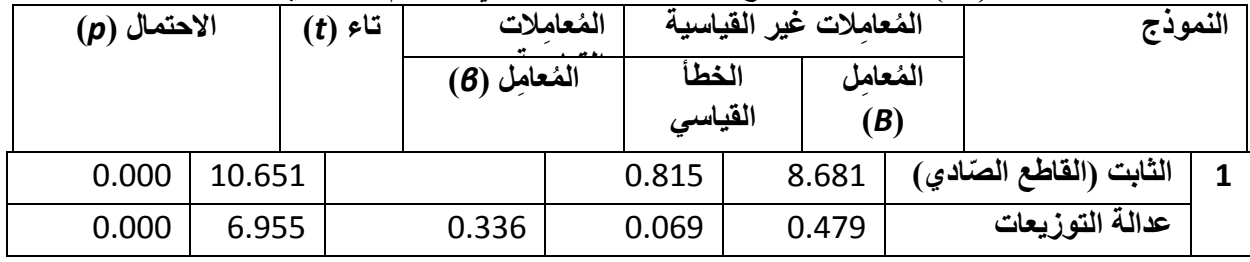

4.3.3 الفرضية الفرعية (3)

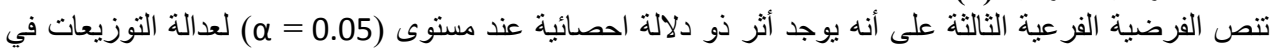

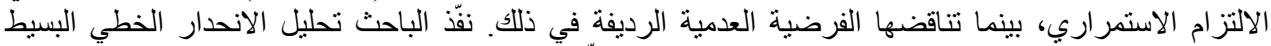

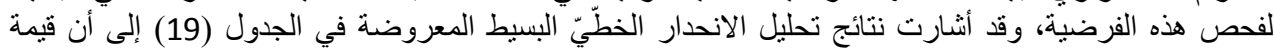

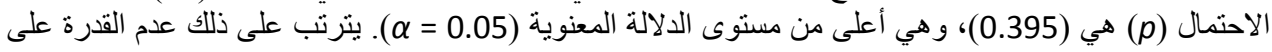

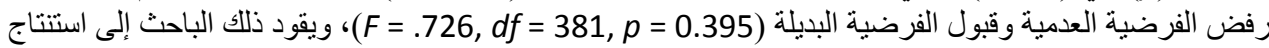

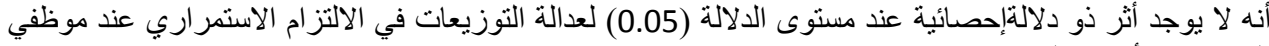
الوزارات الأردنية المدروسة. الجدول (19): تحليل التباين في نموذج أثر عدالة التوزيعات في الالتزام الاستمراري

\begin{tabular}{|c|c|c|c|c|c|c|}
\hline الاحتمال & الدّالّ الإحصائي (F) & المربع المتوسط & الحرّيّة & مجروع & \multicolumn{2}{|c|}{ النموذج } \\
\hline 0.395 & 0.726 & 10.292 & 1 & 10.292 & الانحدا & 1 \\
\hline & & 14.179 & 380 & 5388.119 & المتبقِّي & \\
\hline & & & 381 & 5398.411 & الكَّيّ & \\
\hline
\end{tabular}




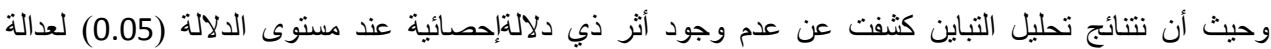

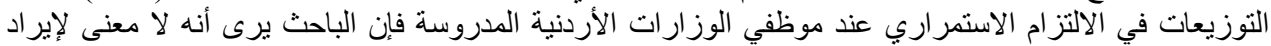

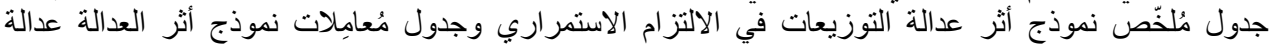

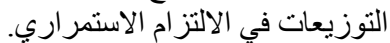

(4) 4.3 .4

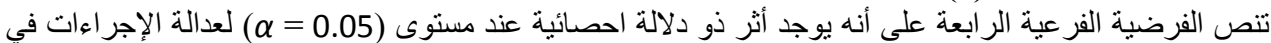

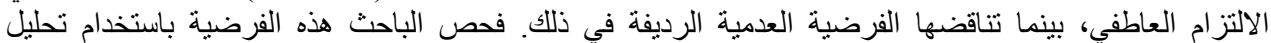

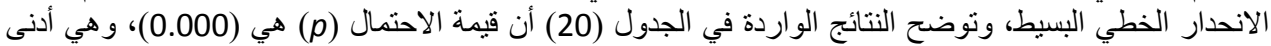

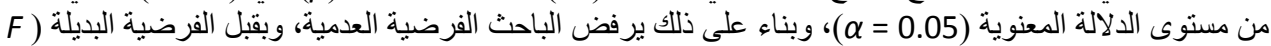

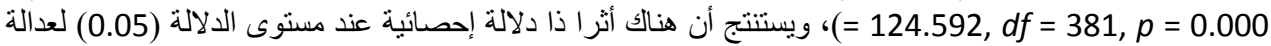
الإجر اءات في الالتزام العاطفي عند موظفي الوزارات الأردنية المدروسة.

\begin{tabular}{|c|c|c|c|c|c|c|}
\hline الاحتمال & الآدالّة الإحصائي & المترسط & الحرَّيّة & المربِعات & \multicolumn{2}{|c|}{ النموذج } \\
\hline \multirow[t]{3}{*}{0.000} & 124.592 & 2039.084 & 1 & 2039.084 & الانحدار & 1 \\
\hline & & 16.366 & 380 & 6219.115 & المتبقِيّي & \\
\hline & & & 381 & 8258.199 & الكلّيّ & \\
\hline
\end{tabular}

تتو افق نتائج تحليل الانحدار التي يوجز ها جدول مُلخَص نموذج أثنر عدالة الإجر اءاتفي الالتز ام العاطفي (الجدول (21)

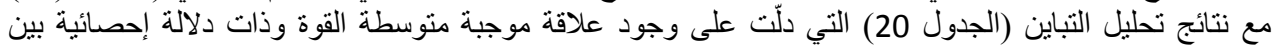

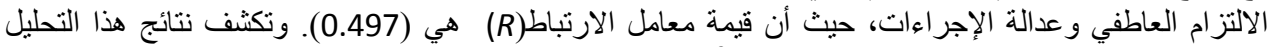

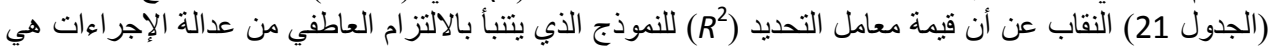

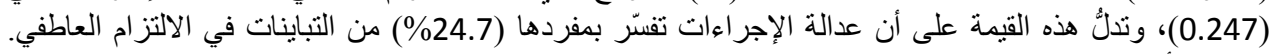

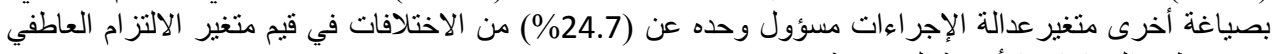

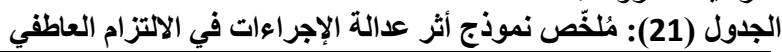

\begin{tabular}{|c|c|}
\hline 0.497 & معامل الارتباط (R) \\
\hline 0.247 & معامل التحديا (R2) \\
\hline 0.245 & معامل التحديد المعدل \\
\hline
\end{tabular}

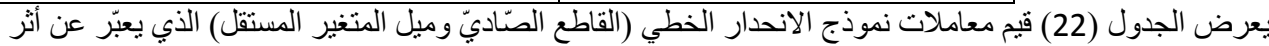

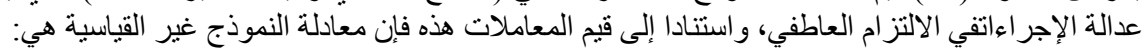
الالتز ام العاطفي = 9.346 + 0.483 * عدالة الإجر اءاتات

$$
\text { الالتز ام العاطفي = } 0.497 \text { * عدالة الإجر اءات }
$$

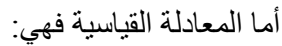

الجدول (22): مُعامِلات نموذج أثر عدالة الإجراءات في الالتزام العاطفي

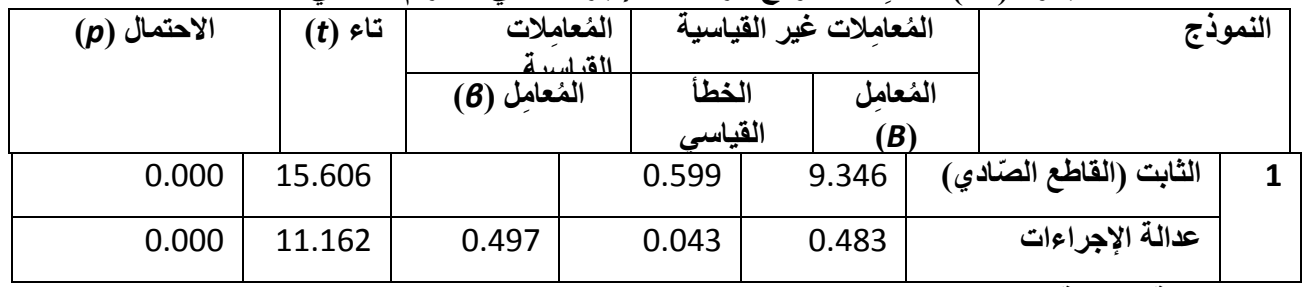

(5) الفرضية الفرعية

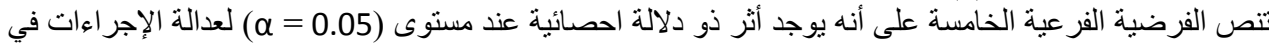

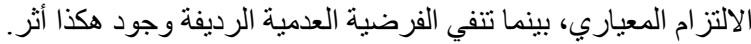


طبّق الباحث تحليل الانحدار الخطي البسيط بهدف فحص هذه الفرضية. وتدلّ النتائج الواردة في الجدول (23) على أن أن

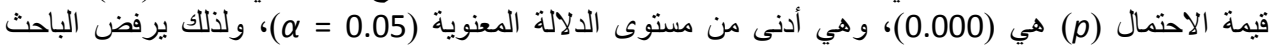

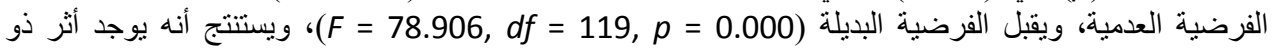

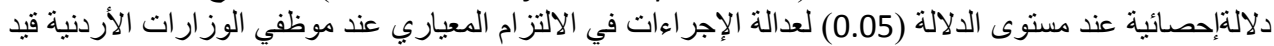

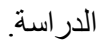
الجدول (23): تحليل التباين في نموذج أثر عدالة الإجراعات في الالتزام المعياري

\begin{tabular}{|c|c|c|c|c|c|c|}
\hline الاحتمال & الَ الإحصائي & متوسط & رحرَّيَة & بَعات & & النموذج \\
\hline \multirow[t]{3}{*}{0.000} & 78.906 & 1595.119 & 1 & 1595.119 & الاتحدار & 1 \\
\hline & & 20.216 & 380 & 7681.899 & المتبقِّي & \\
\hline & & & 381 & 9277.018 & الكلَّي & \\
\hline
\end{tabular}

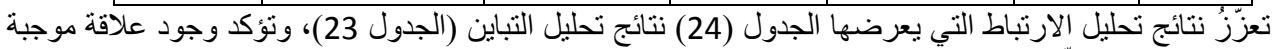

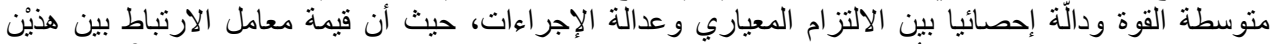

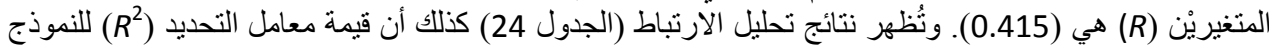

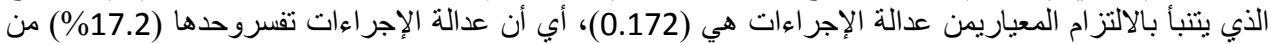
الاختلافات فيمتغير الالتزام المعياري عند موظفي الوزارات الات الأردنية المدروسة.

الجدول (24): مُلخّص نموذج أثر عدالة الإجراءات في الالتزام المعياري

\begin{tabular}{|c|c|}
\hline 0.415 & معامل الارتباط (R) \\
\hline 0.172 & معامل التحديد (R2) \\
\hline 0.170 & معامل التحديد المعدل \\
\hline
\end{tabular}

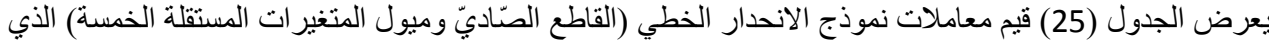

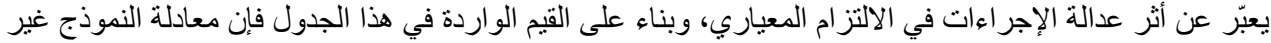
الالتز ام المعياري = 8.555 +0.427 * عدالة الإجر اءات

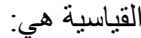

الالتز ام المعياري = 0.415 * عدالة الإجر اءات الات فئزات أما المعادلة القياسية فتأخذ الصيغة: الصات

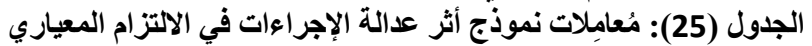

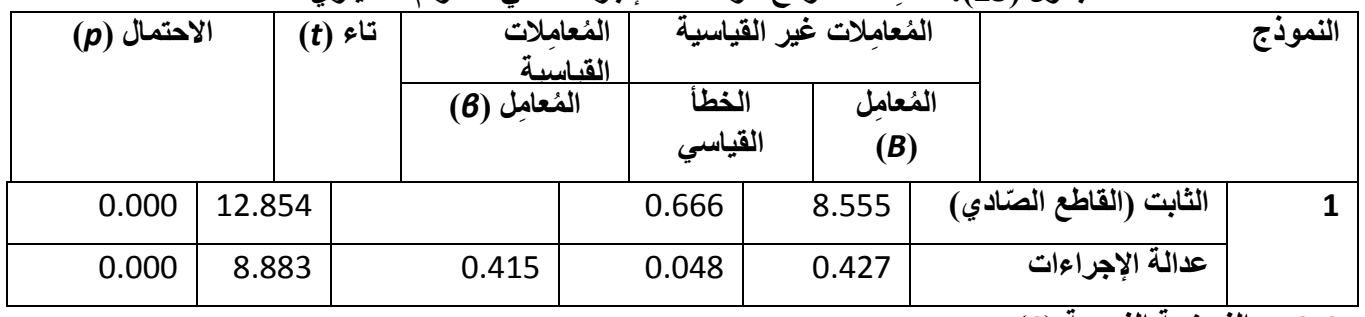

4.3.6 الفرضية الفرعية (6) الفرية

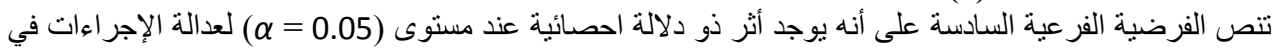

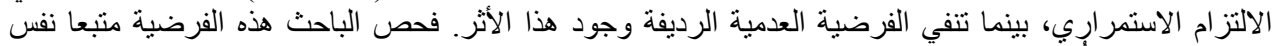

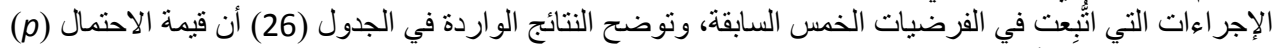

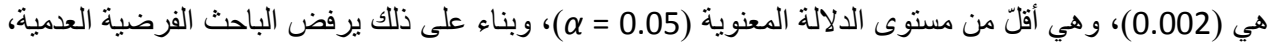
ويقبل الفرضية البديلة (0.002)

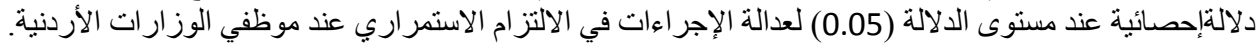


The Influence of Organizational Justice on Job Commitment in the Jordanian Ministries

الجدول (26): تحليل التباين في نموذج أثر عدالة الإجراءات في الالتزام الاستمراري

\begin{tabular}{|c|c|c|c|c|c|c|}
\hline الاحتمال & الآّالَ الإحصائي (F) & المربع المتوسط & درجة الحرّيّة & المجبِّوع & \multicolumn{2}{|c|}{ النموذج } \\
\hline 0.002 & 9.469 & 131.250 & 1 & 131.250 & الانحدار & 1 \\
\hline & & 13.861 & 380 & 5267.161 & المتبقِّي & \\
\hline & & & 381 & 5398.411 & الكلَيّ & \\
\hline
\end{tabular}

تتو افق نتائج نحليل الانحدار المعروضة ضمن مُلخّص نموذج أنزر عدالة الإجر اءات في الالتز ام الاستمر اري (الجدول

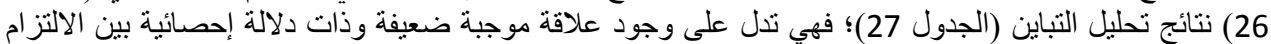

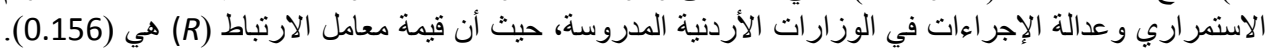

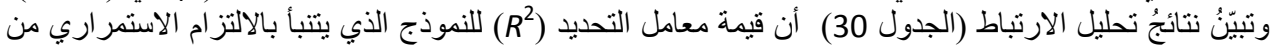

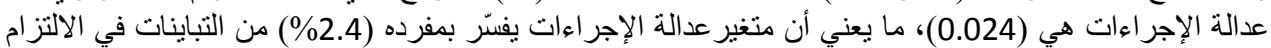
الاستمر اري عند موظفي الوزار الات الأردنية المدروسة.

الجدول (27): مُلخّص نموذج أثثر عدالة الإجراءات في الالتزام الاستمراري

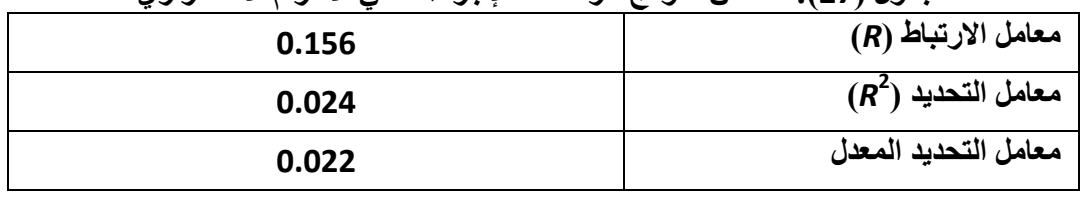

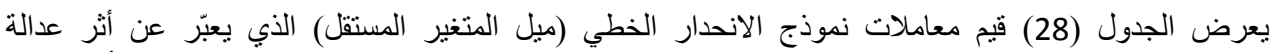

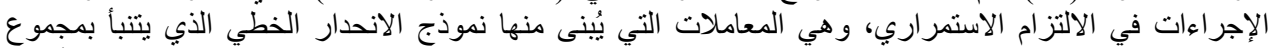

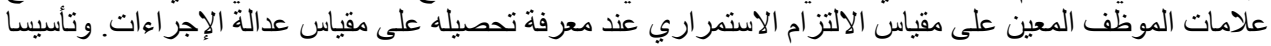
على مخرجات تحليل الانحدار هذه فإن معادلة النموذج غير الإنير القياسية هي: الالتز ام الاستمر اري = 13.369 + 0.123 * عدالة الإنجر اءعات

الالتز ام الاستمر اري = 0.156 * عدالة الإجر اءات

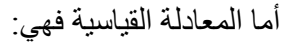

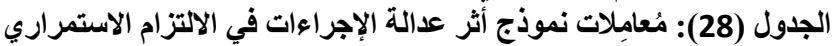

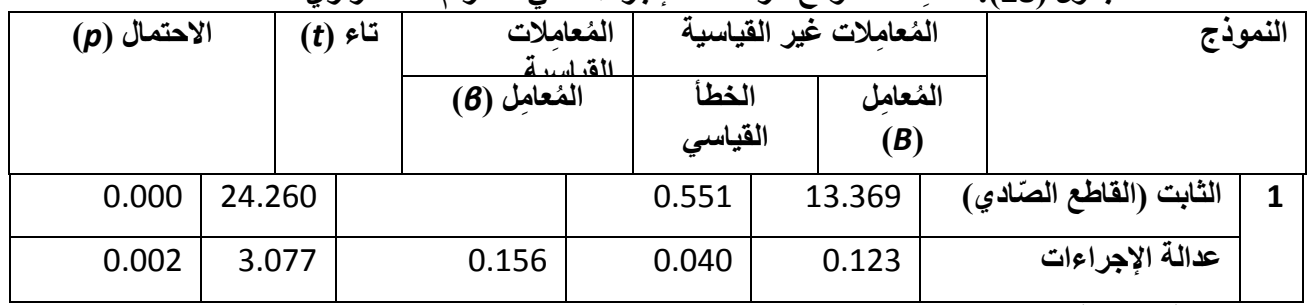

(7) 4.3 .7

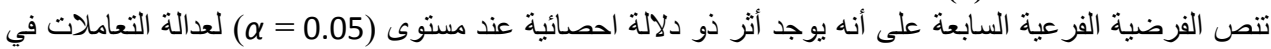

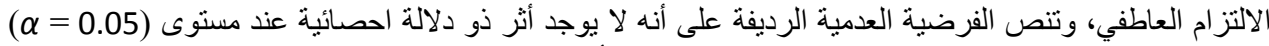

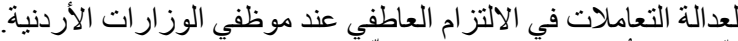

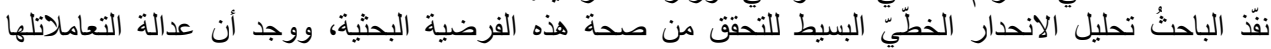

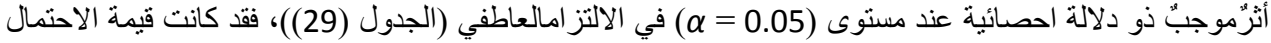

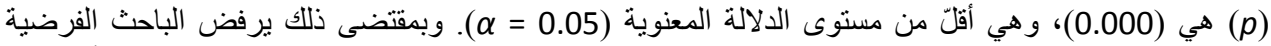

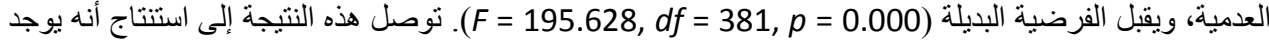

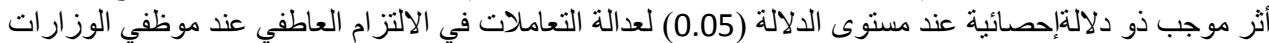
الأردنية. 
Journal of Social Sciences (COES\&RJ-JSS), 8(2), pp.230-269

\begin{tabular}{|c|c|c|c|c|c|c|}
\hline الاحتمال & $\begin{array}{r}\text { الدّالَّ الإحصائي } \\
\text { (F) }\end{array}$ & المتربيع & لحرِيّة & مبِعات & & النموذج \\
\hline \multirow[t]{3}{*}{0.000} & 195.628 & 2806.563 & 1 & 2806.563 & الاتحدار & 1 \\
\hline & & 14.346 & 380 & 5451.636 & المتبقِّي & \\
\hline & & & 381 & 8258.199 & الكلَّي & \\
\hline
\end{tabular}

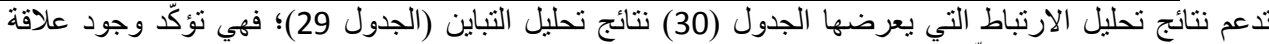

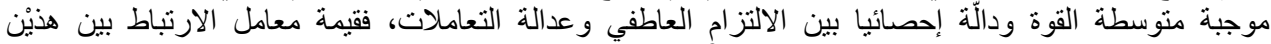

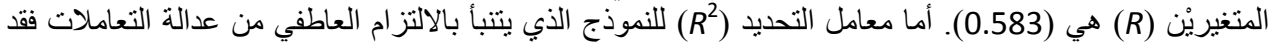

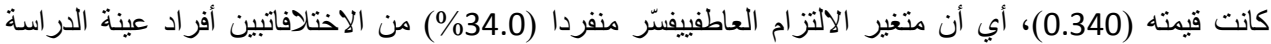

الجدول (30): مُلخّص نموذج أثر عدالة التعاملات في الالتزام العاطفي

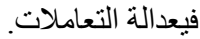

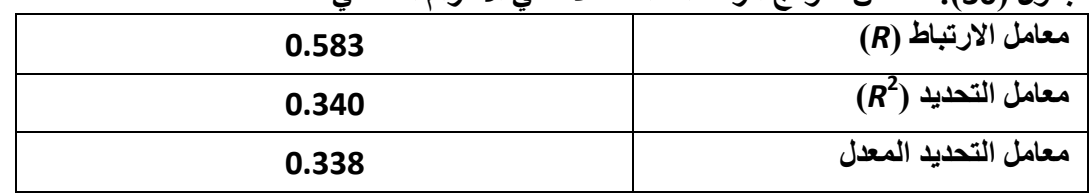

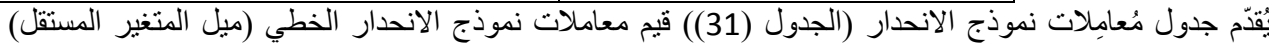

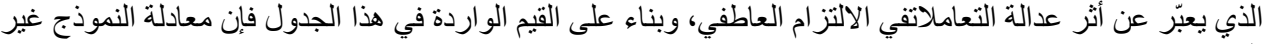
القياسية هي: الالتز ام العاطفي = 0.017 + 0.358 * عدالة التعاملات

الالتز ام العاطفي = 0.583 * عدالة التعاملات

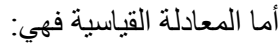

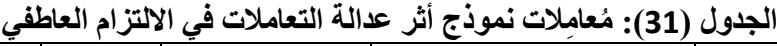

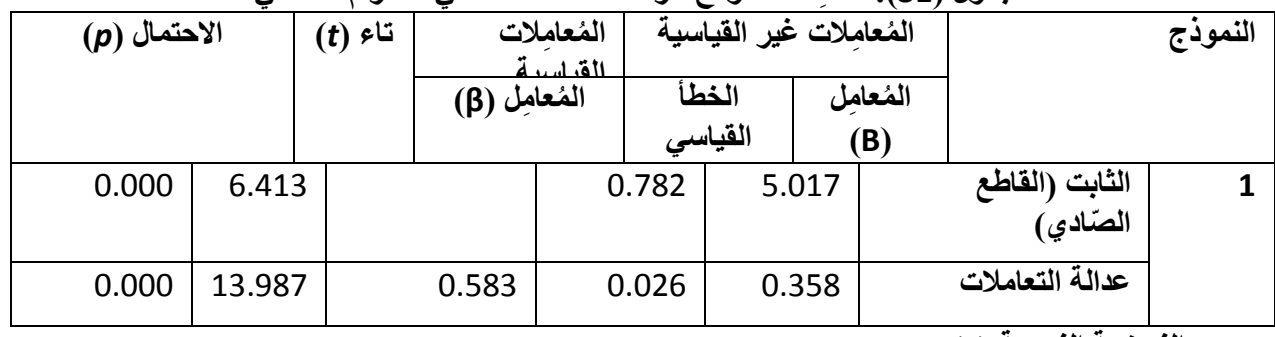

(8) 4.3 .8

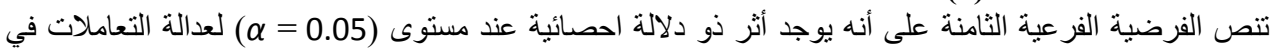

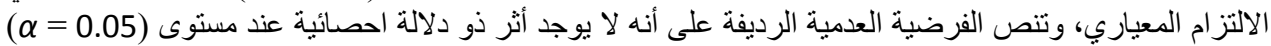

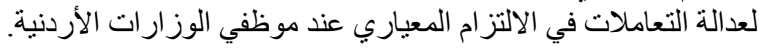

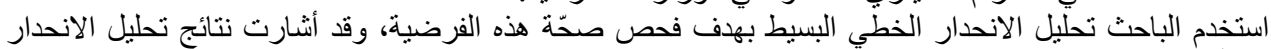

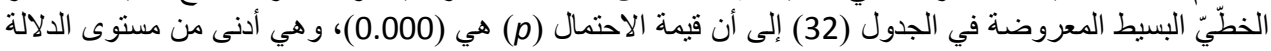

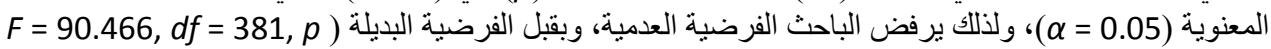

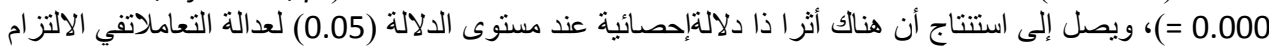

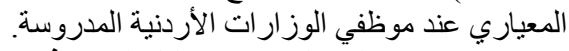
الجدول (32): تحليل التباين في نموذجة أثر عدالة التُونة التعاملات في الالتزام المعياري

\begin{tabular}{|c|c|c|c|c|c|c|}
\hline الاحتمال & الدّالَ الإحصائي (F) & المترسط & الحرّيّة & مجربِّوع & & \\
\hline \multirow[t]{3}{*}{.000} & 90.466 & 1783.876 & 1 & 1783.876 & الانحدار & 1 \\
\hline & & 19.719 & 380 & 7493.143 & المتبقِي & \\
\hline & & & 381 & 9277.018 & الكلَّي & \\
\hline
\end{tabular}




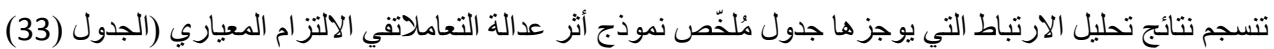

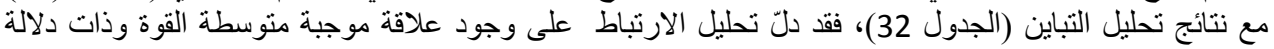

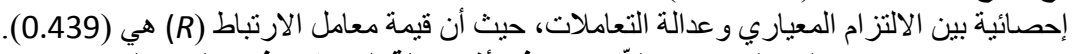
الجدول (33): مُلخِص نموذج أثران عدالة التعاملات في الالتزام المعياري

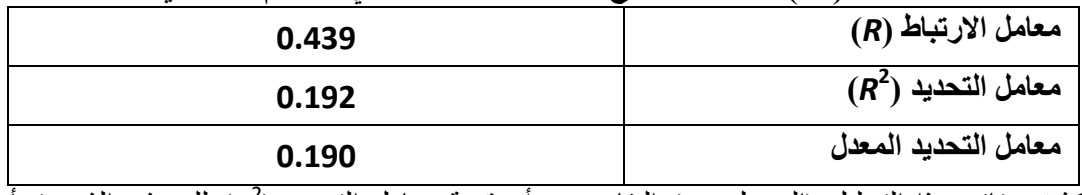

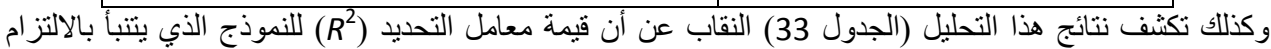

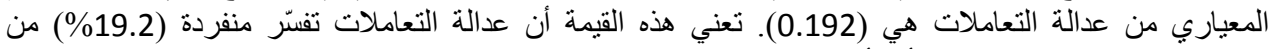

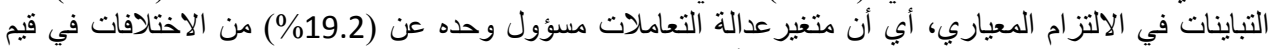

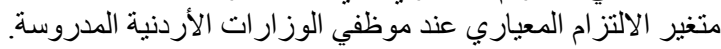

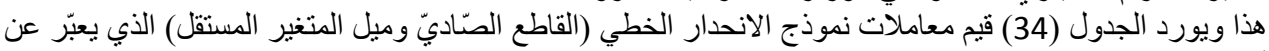

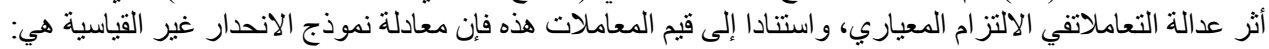

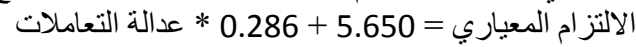

الالتز ام المعياري = 0.439 * عدالة التعامئل

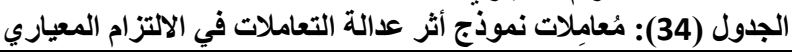

\begin{tabular}{|c|c|c|c|c|c|c|c|c|c|}
\hline \multirow{2}{*}{\multicolumn{2}{|c|}{ الاحتمال (p) }} & \multirow[t]{2}{*}{ تاء (t) } & \multirow{2}{*}{\multicolumn{2}{|c|}{ 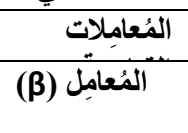 }} & \multicolumn{3}{|c|}{ المُعامِلات غير القياسية } & & \multirow[t]{2}{*}{ النموذج } \\
\hline & & & & & القياسئ & \multicolumn{2}{|c|}{$\begin{array}{c}\text { المُعامِل } \\
\text { (B) }\end{array}$} & & \\
\hline 0.000 & 6.161 & & & & 0.917 & 5.650 & & الثابت (القاطع الصّاً & 1 \\
\hline 0.000 & 9.511 & & 0.439 & & 0.030 & 0.286 & & عدالة التعاملات & \\
\hline
\end{tabular}

4.3.9 الفرضية الفرعية (9)

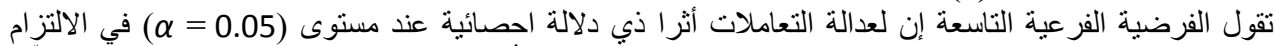

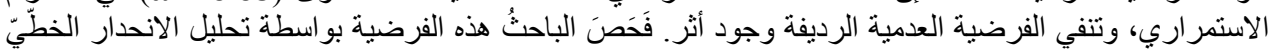

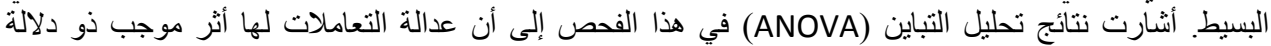

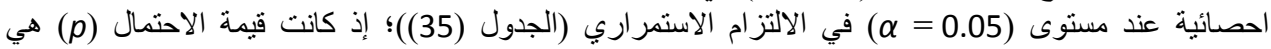

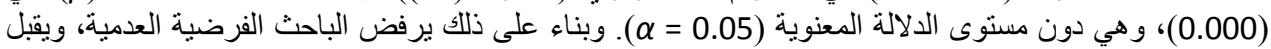
الفرضية البديلة (0.000)

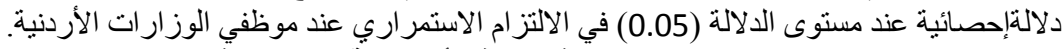

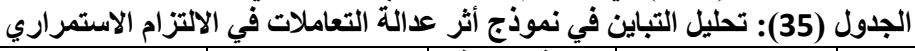

\begin{tabular}{|c|c|c|c|c|c|c|}
\hline الاحتمال & الدّالّ الإحصائي (F) & المربع المتوسط & درجة الحرّيّة & المربّعات & & النمو - النو \\
\hline \multirow[t]{3}{*}{0.000} & 21.566 & 289.924 & 1 & 289.924 & الانحدار & 1 \\
\hline & & 13.443 & 380 & 5108.487 & المتبقُّي & \\
\hline & & & 381 & 5398.411 & الكلْيّ & \\
\hline
\end{tabular}

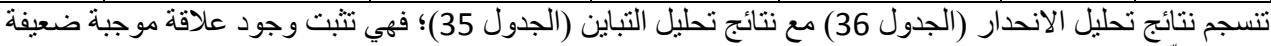

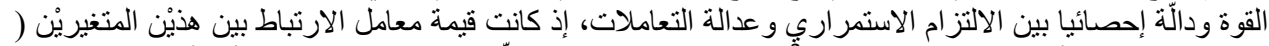

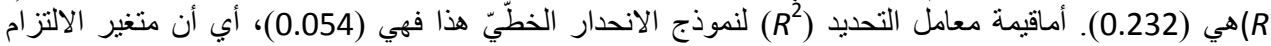

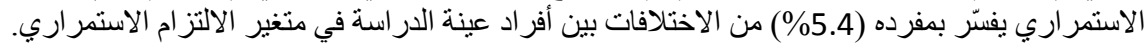

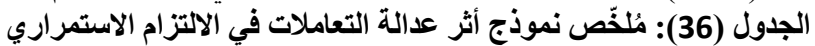

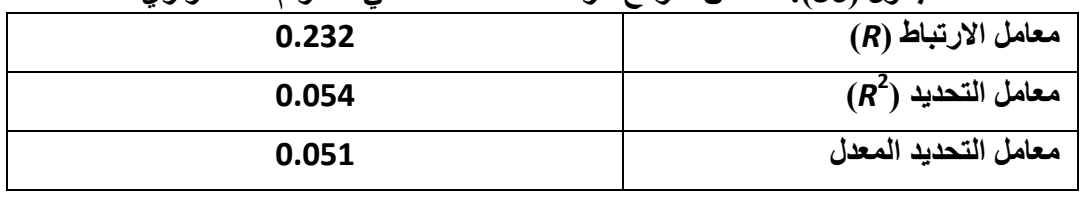


أما مُعامِلات نموذج تكميم أثنر عدالة التعاملات في الالتزام الاستمراري (ميل المتغير المستقل) فيلخّصها الجدول

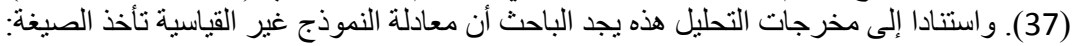

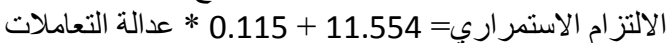

الالنز ام الاستمر اري= 0.232 * عدالة التعاملات

وتكون المعادلة القياسية:

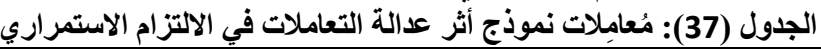

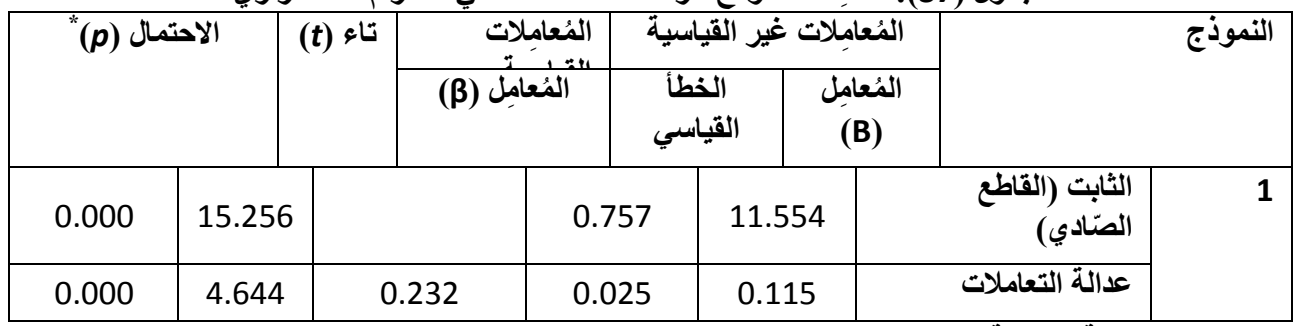

4.3.10 الفرضية الفرعية (10)

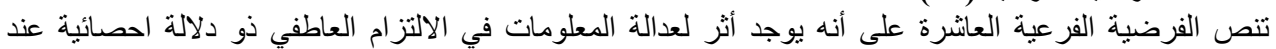

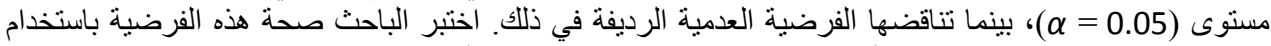

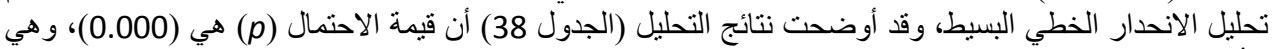

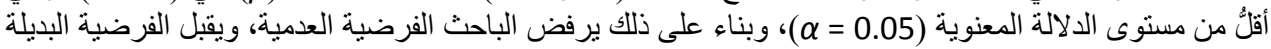

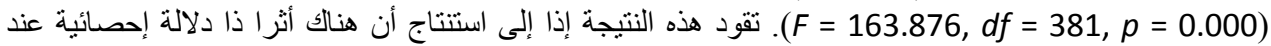

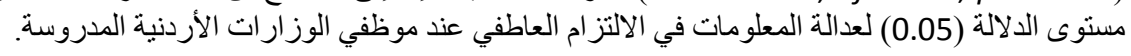

الجدول (38): تحليل التباين في نموذج أثر عدالة المعلومات في الالتزام العاطفي

\begin{tabular}{|c|c|c|c|c|c|c|}
\hline الاحتمال & الدّالّ الإحصائي (F) & لمربع & درجة الحرّيّة & المربّعات & & النموذج \\
\hline \multirow[t]{3}{*}{0.000} & 163.876 & 2488.294 & 1 & 2488.294 & الانحدار & 1 \\
\hline & & 15.184 & 380 & 5769.905 & المتبقِي & \\
\hline & & & 381 & 8258.199 & الكلَّيّ & \\
\hline
\end{tabular}

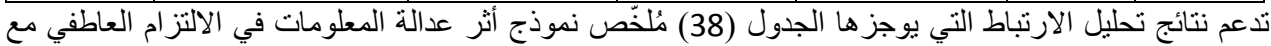

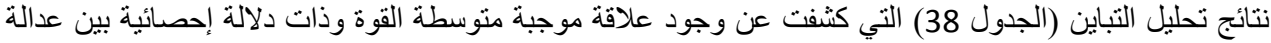

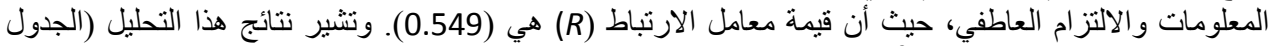

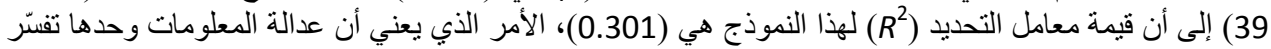

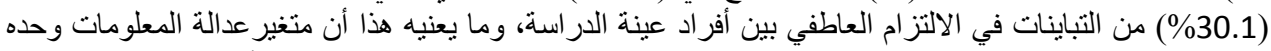

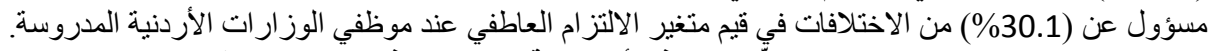

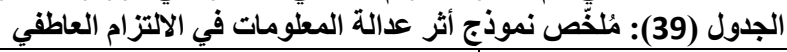

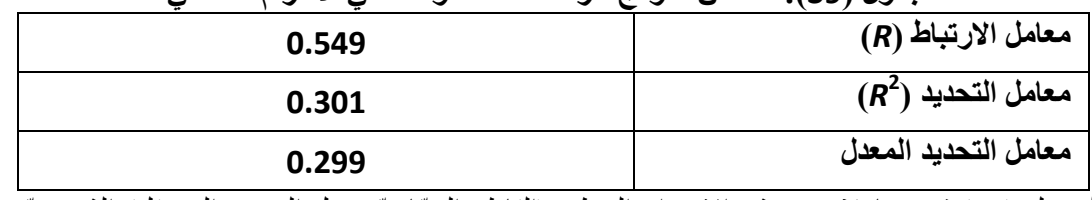

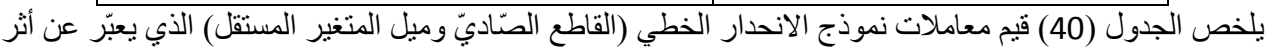

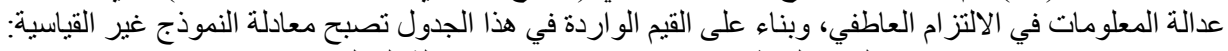
الالتزام العاطفي = 7.655 +0.543 * عدالة المعلومات

الالتز ام العاطفي = 0.543 * عدالة المعلومات

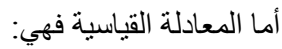


The Influence of Organizational Justice on Job Commitment in the Jordanian Ministries

الجدول (40): مُعامِلات نموذج أثر عدالة المعلومات في الالتزام العاطفي

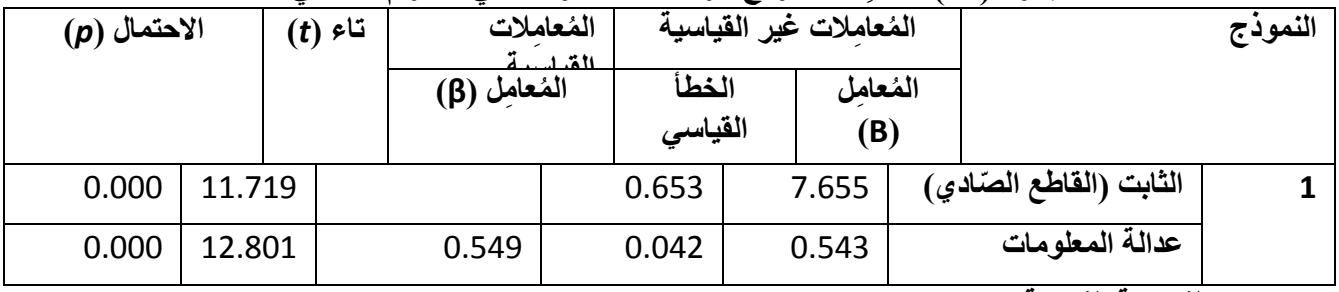

4.3.11 الفرضية الفرعية (11)

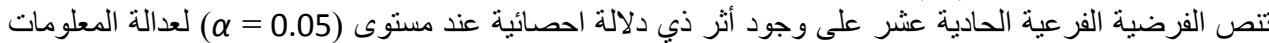

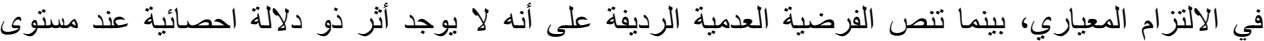

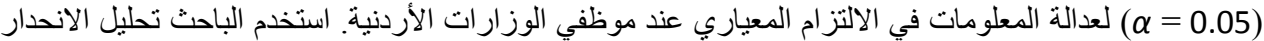

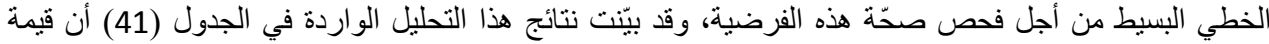

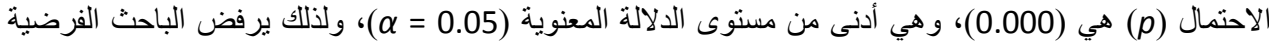

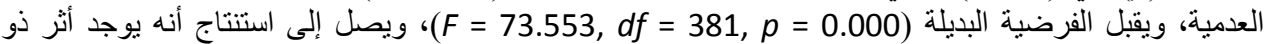

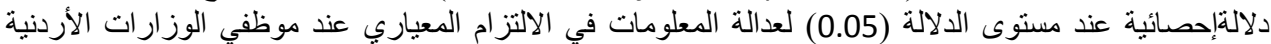

الجدول (41): تحليل التباين في نموذج أثر عدالة المعلومات في الالتزام المعياري المدروسة.

\begin{tabular}{|c|c|c|c|c|c|c|}
\hline الاحتمال & الآّالّ الإحصائي (F) & المريع المتوسط & درجة الحرّيّة & المجربّعات & \multicolumn{2}{|c|}{ النموذج } \\
\hline \multirow[t]{3}{*}{0.000} & 73.553 & 1504.464 & 1 & 1504.464 & الانحدار & 1 \\
\hline & & 20.454 & 380 & 7772.554 & المتبقِّي & \\
\hline & & & 381 & 9277.018 & الكلَّي & \\
\hline
\end{tabular}

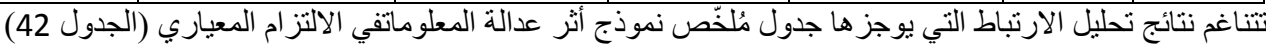

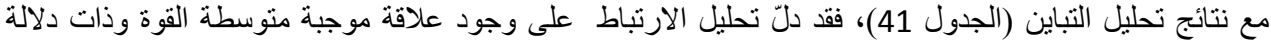

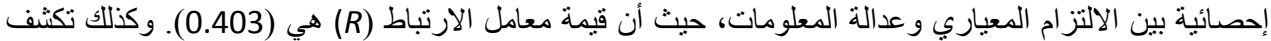

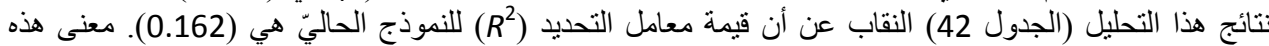

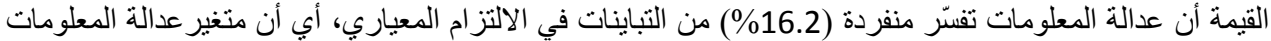

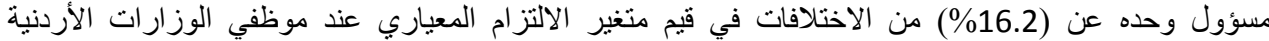

الجدول (42): مُلخّص نموذج أثر عدالة المعلومات في الالتزام المعياري

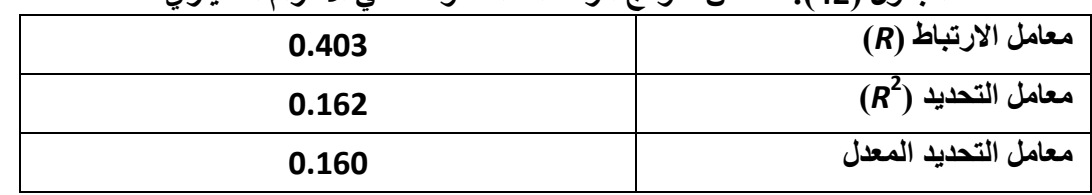

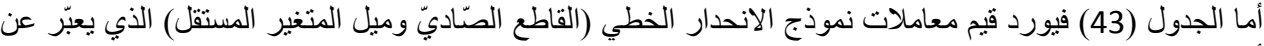

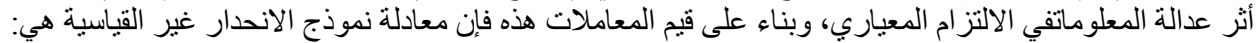

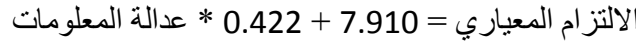

الالتز ام المعياري = 0.403 * عدالة المعلومات المعات

الجدول (43): مُعامِلات نموذج أثر عدالة المعلومات في الالتزام المعياري المعاري

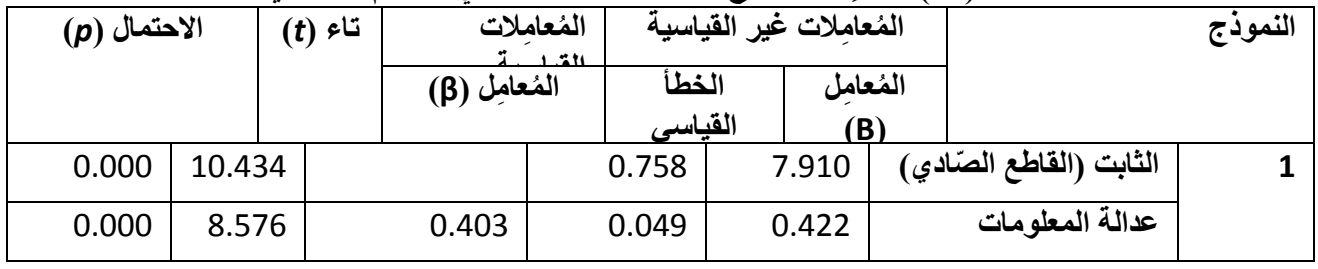


4.3.12 الفرضية الفرعية (12)

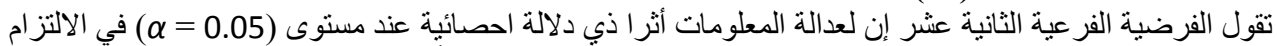

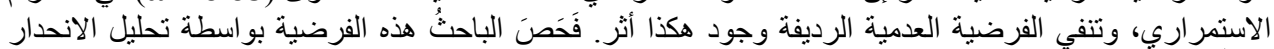

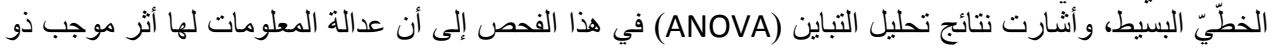

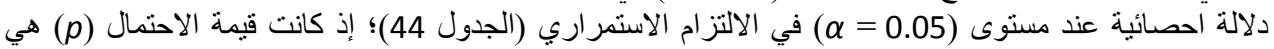

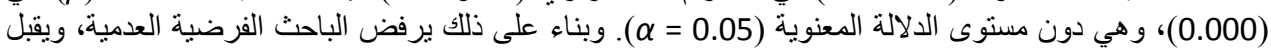
الفرضية البديلة (0.00)

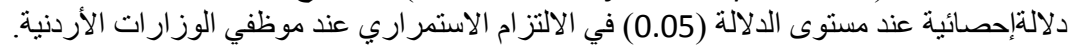

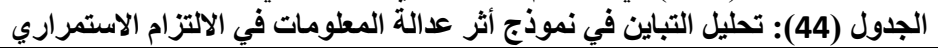

\begin{tabular}{|c|c|c|c|c|c|c|}
\hline الاحتمال & الآالَ الإحصائي (F) & المربع المتوسط & درجة الحرّيّة & المربّعات & & النمو - النو \\
\hline \multirow[t]{3}{*}{0.000} & 18.618 & 252.135 & 1 & 252.135 & الاتحدار & 1 \\
\hline & & 13.543 & 380 & 5146.276 & المتبقِي & \\
\hline & & & 381 & 5398.411 & الكلَّيّ & \\
\hline
\end{tabular}

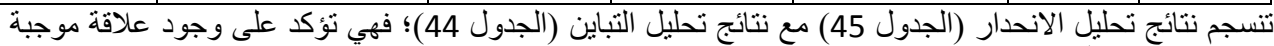

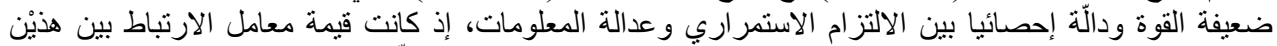

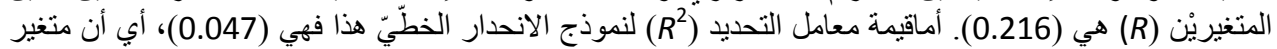

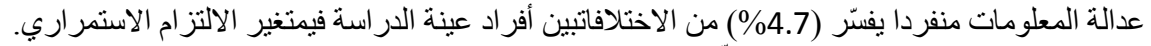

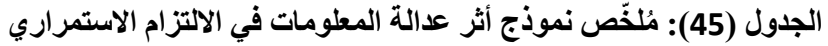

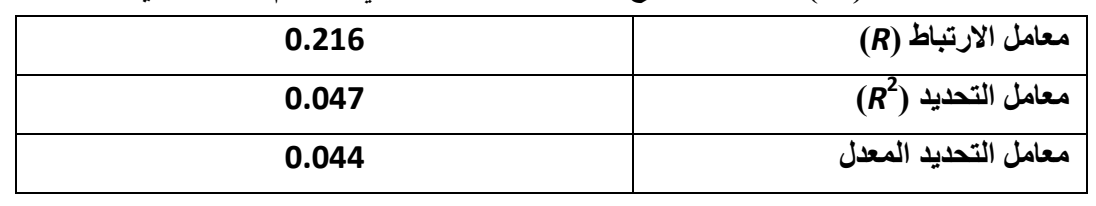

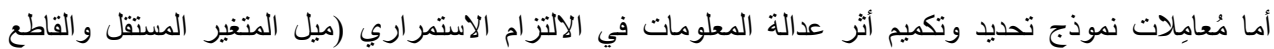

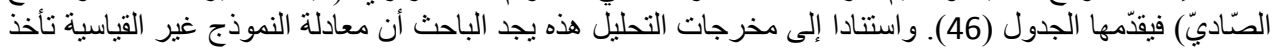

الالتز ام الاستمر اري= 12.426 + 0.173 * عدالة المعلومات

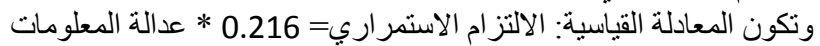

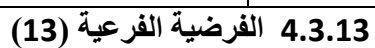

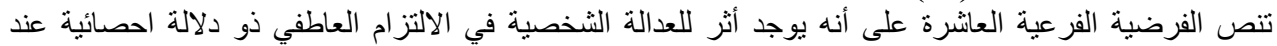

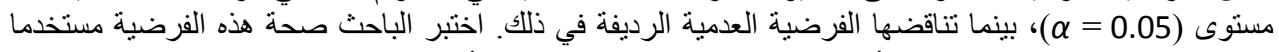

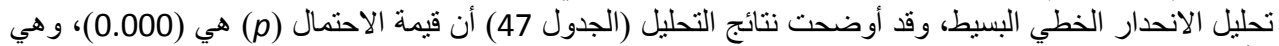

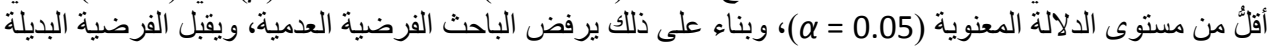
(F= 126.989, df = 381, $p=0.000$ ) مستوى الدلالة (0.05) للعدالة الثخصية في الالتزام العاطفي عند موظفي الوزارات الأردنية المدروسة. 
The Influence of Organizational Justice on Job Commitment in the Jordanian Ministries

\begin{tabular}{|c|c|c|c|c|c|c|}
\hline الاحتمال & لادّالَ الإحصائي & المريع & درجة & \multicolumn{2}{|c|}{ مجموع } & النموذج \\
\hline \multirow[t]{3}{*}{0.000} & 126.989 & 2068.483 & 1 & 2068.483 & الاتحدار & 1 \\
\hline & & 16.289 & 380 & 6189.716 & المتبقي & \\
\hline & & & 381 & 8258.199 & الكلّيّ & \\
\hline
\end{tabular}

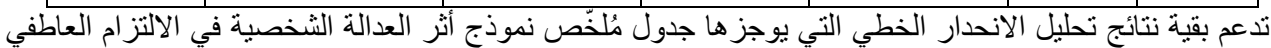

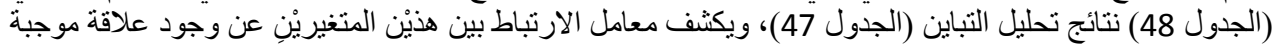

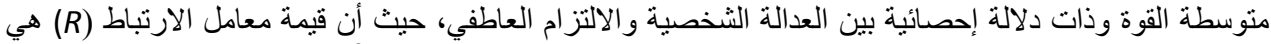

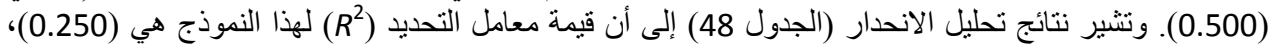

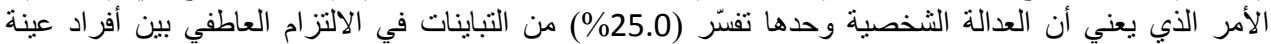

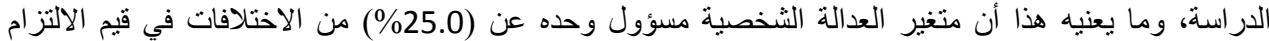
العاطفي عند موظفي الوزار ات الأردنية المدروسة. الجدول (48): مُلخّص نموذجة أثر العدالة الثخصية في الالتزام العاطفي

\begin{tabular}{|c|c|}
\hline 0.500 & معامل الارتباط (R) \\
\hline 0.250 & معامل التحديد (R2) \\
\hline 0.249 & معامل التحديد المعدل \\
\hline
\end{tabular}

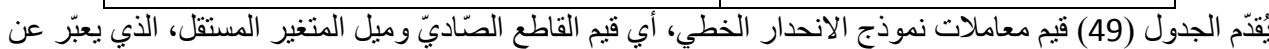

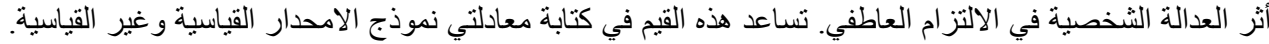

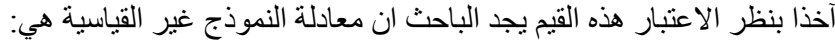

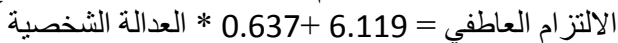

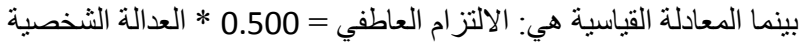
الجدول (49): مُعامِلات نموذج أثر العدالة الثخصية في الالتز التمام العاطفي

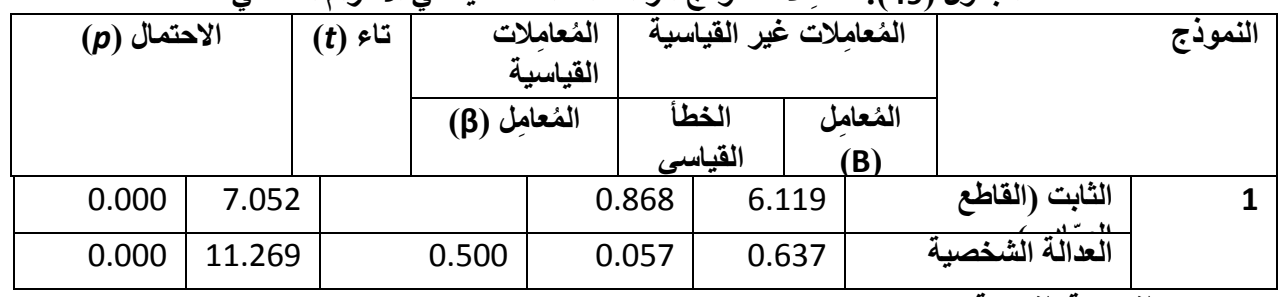

4.3.14 الفرضية الفرعية (14)

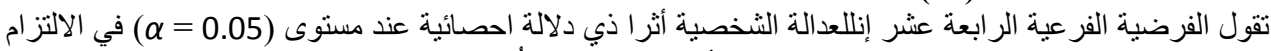

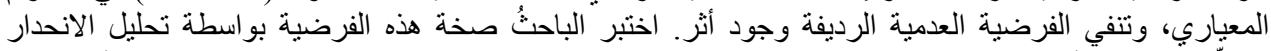

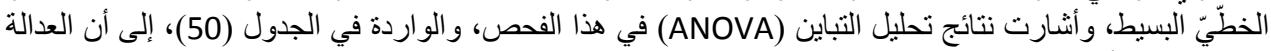

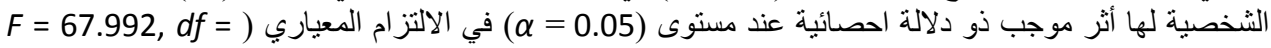
0.000

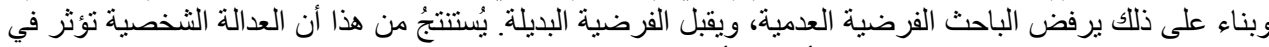

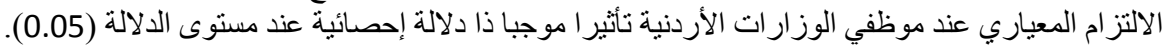

الجدول (50): تحليل التباين في نموذج أثر العدالة الثخصية في الالتزام المعياري

\begin{tabular}{|c|c|c|c|c|c|c|}
\hline الاحتمال & الدّالَ الإحصائي (F) & المتوسيع & الحرَّيّة & المجربّعات & & النموذج \\
\hline \multirow[t]{3}{*}{0.000} & 67.992 & 1407.976 & 1 & 1407.976 & الانحدار & 1 \\
\hline & & 20.708 & 380 & 7869.042 & المتبقِي & \\
\hline & & & 381 & 9277.018 & الكلْيّ & \\
\hline
\end{tabular}


تتسجم نتائج تحليل الانحدار الأخرى (الجدول 51) مع نتائج تحليل التباين (الجدول 50)؛ فهي تتبت وجود التباد علاقة

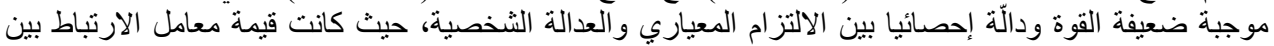

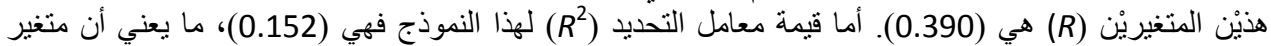

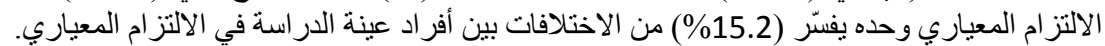

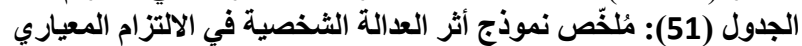

\begin{tabular}{|c|c|}
\hline 0.390 & معامل الارتباط (R) \\
\hline 0.152 & معامل التحديد (R2) \\
\hline 0.150 & معامل التحديد المعدل \\
\hline
\end{tabular}

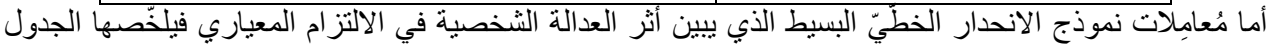

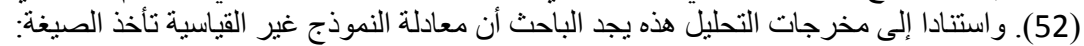

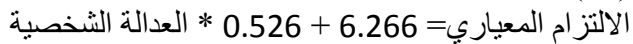
وتكون المعادلة القياسية: الالتز ام المعياري= 0.390 * 0.526 * العدالة الثخصية

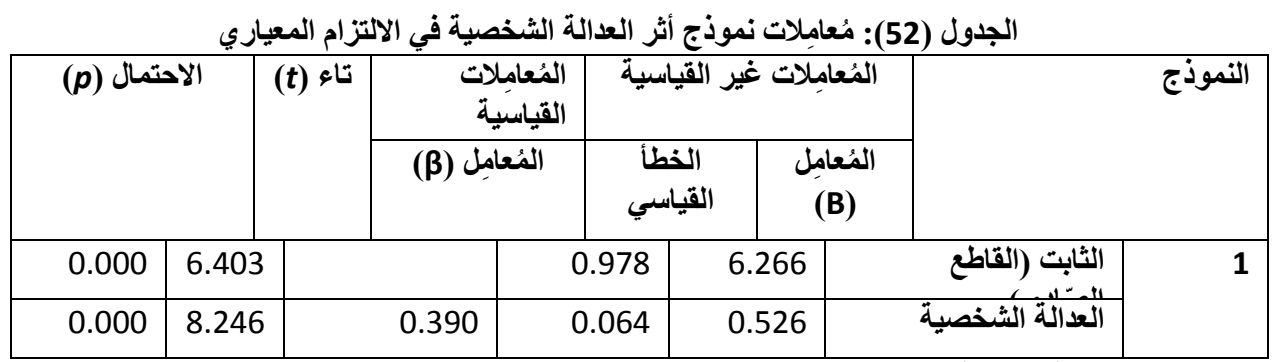

4.3.15 الفرضية الفرعية (15)

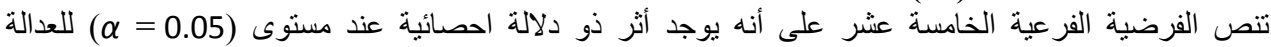

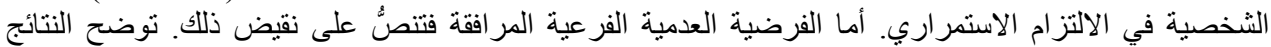

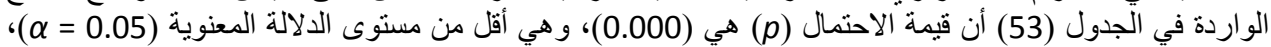

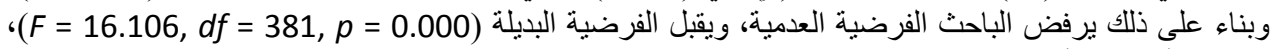

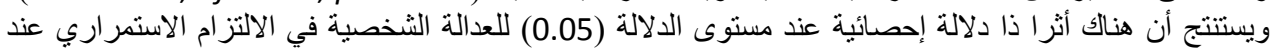
موظفي الوزارات الأردنية. الجدول (53): تحليل التباين في نموذج أثر العدالة الثخصية في الالتزام الاستمراري

\begin{tabular}{|c|c|c|c|c|c|c|}
\hline الاحتمال & الدالّ الإحصائي (F) & المربع المتوسط & درجة الحرّيّة & لمرَّعات & \multicolumn{2}{|c|}{ النموذج } \\
\hline 0.000 & 16.106 & 219.509 & 1 & 219.509 & الاتحدار & 1 \\
\hline & & 13.629 & 380 & 5178.902 & المتبقِي & \\
\hline & & & 381 & 5398.411 & الكلَّيّ & \\
\hline
\end{tabular}

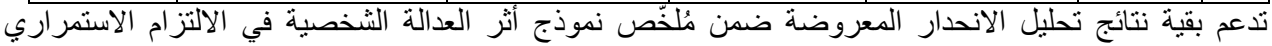

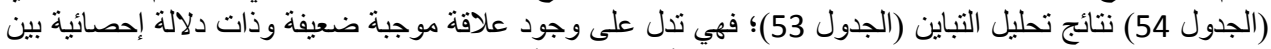

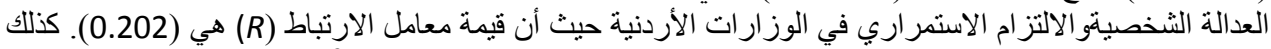

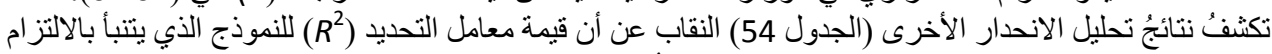

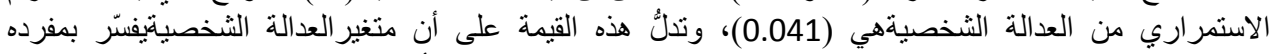

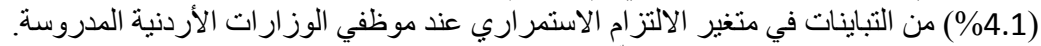

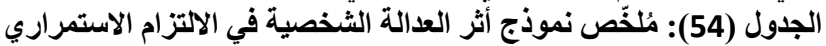

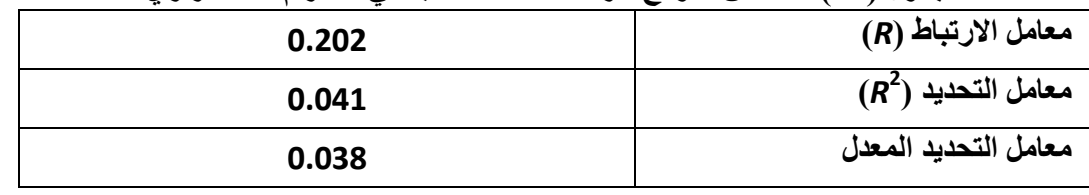


يوجز الجدول (55) قيم معاملات نموذج الانحدار الخطي الذي يعبّر عن أثر العدالة الثخصية في الالتزام

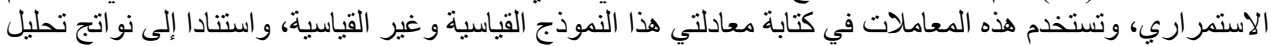

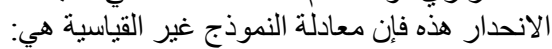

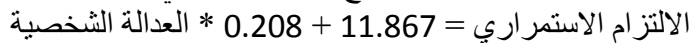

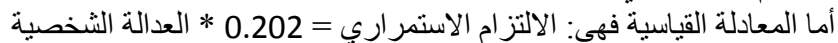

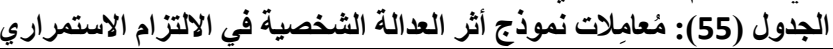

\begin{tabular}{|c|c|c|c|c|c|c|c|}
\hline \multicolumn{2}{|c|}{ الاحتمال (p)" } & (t) 8 & قُمَعاسِيةلاتِ & \multicolumn{2}{|c|}{ المُعامِلات غير القياسية } & \multicolumn{2}{|c|}{ النموذج } \\
\hline & \multirow{2}{*}{\multicolumn{2}{|c|}{\begin{tabular}{r|}
14.94 \\
9
\end{tabular}}} & & \multirow[b]{2}{*}{0.794} & \multirow[b]{2}{*}{11.867} & \multirow{2}{*}{ الثّادي) (القاطع } & \multirow[t]{2}{*}{1} \\
\hline & & & & & & & \\
\hline 0.000 & \multicolumn{2}{|c|}{4.013} & 0.202 & 0.052 & 0.208 & \multicolumn{2}{|l|}{ العدالة الشخصية } \\
\hline
\end{tabular}

وبعد عرض نتائج فحص الفرضيات الفرعية الخمسة عشر ومناقثنة هذه النتائج، يستعرض الباحث في الفقرات التالية

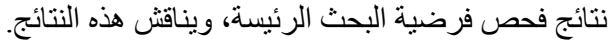
4.3.16 الفرضية الرئيسة

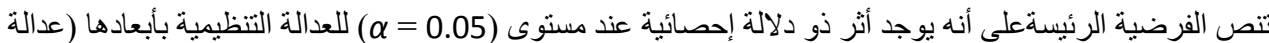

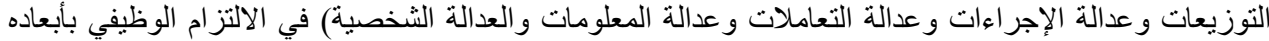

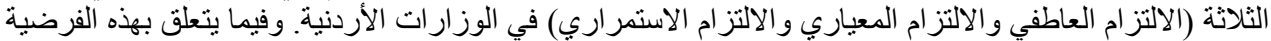

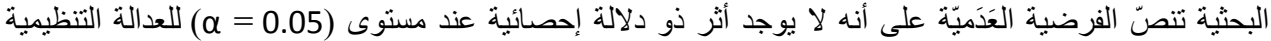

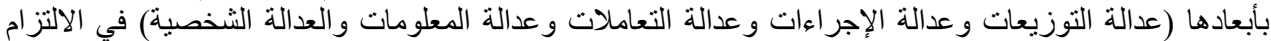

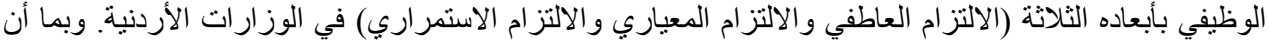

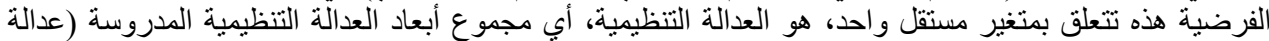

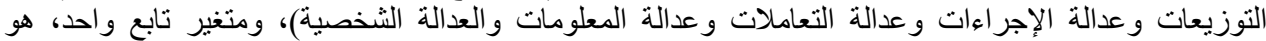

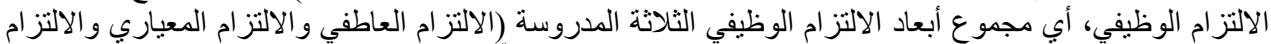

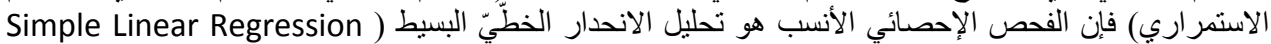

(Analysis

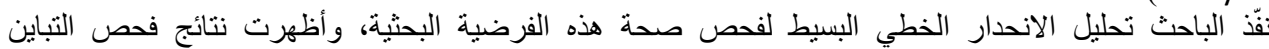
(ANOVA)

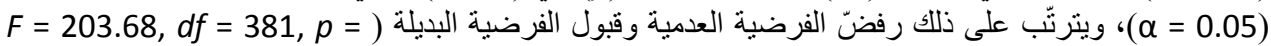

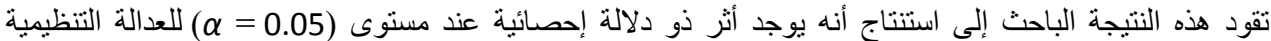

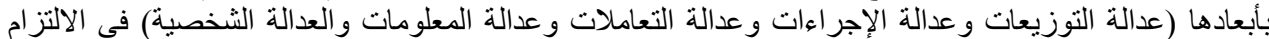

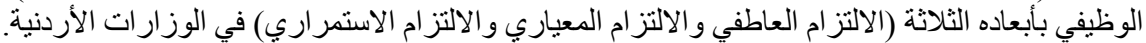

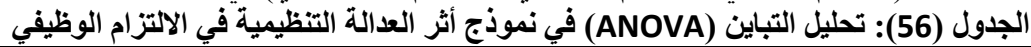

\begin{tabular}{|c|c|c|c|c|c|c|}
\hline الاحتمال & الدّالَ الإحصائي (F) & المترسط & درجة الحرّيّة & المجربّعات & \multicolumn{2}{|c|}{ النموذج } \\
\hline 0.000 & 203.683 & 12888.930 & 1 & 12888.930 & الانحدار & 1 \\
\hline & & 63.279 & 380 & 24046.107 & المتبقِي & \\
\hline & & & 381 & 36935.037 & الكَّيَ & \\
\hline
\end{tabular}

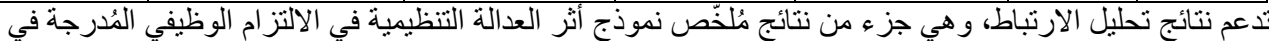

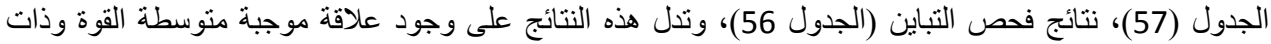

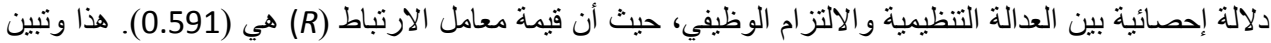

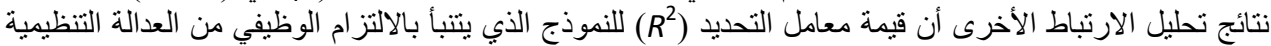

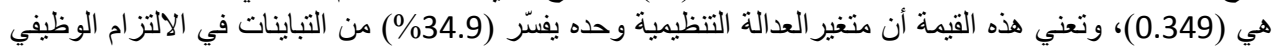
عند موظفي الوزارات الأردنية. 


\begin{tabular}{|c|c|}
\hline 0.591 & معامل الارتباط (R) \\
\hline 0.349 & معامل التحديد (R2) \\
\hline 0.347 & معامل التحديد المعدل \\
\hline
\end{tabular}

يعرض الجدول (58) قيم معاملات نموذج الانحدار الخطي (ميل المتغير المستقل) الذي يمثل ويُكمّم أثر العدالة

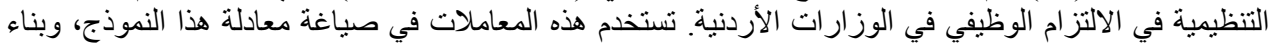

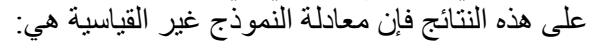

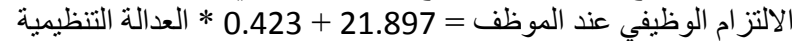
أما المعادلة القياسية فهي: الالتز ام الوظيفي عند الموظف = 0.591 * العدالة التنظيمية

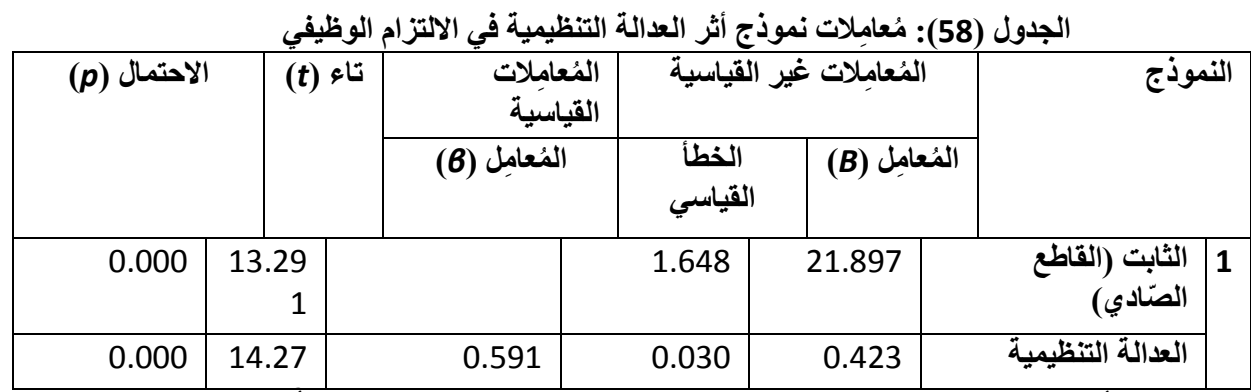

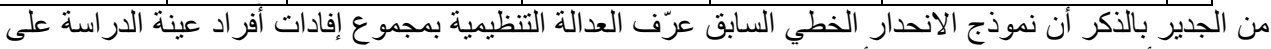

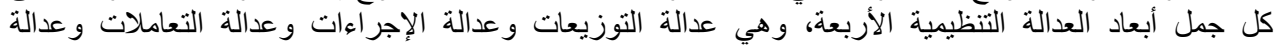

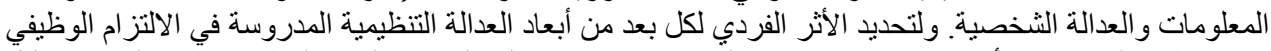

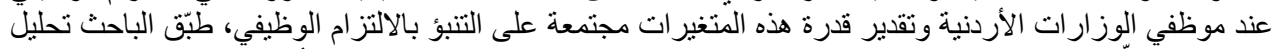

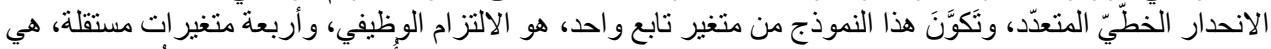

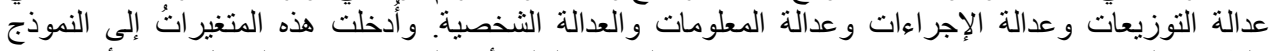

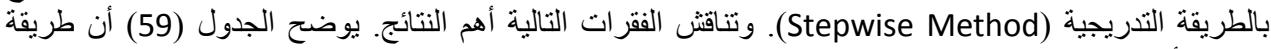

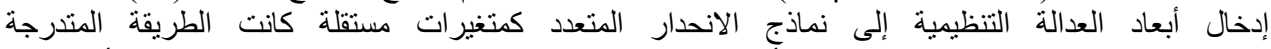

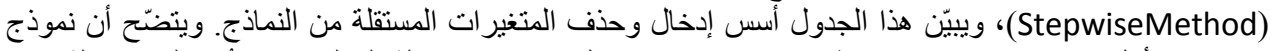

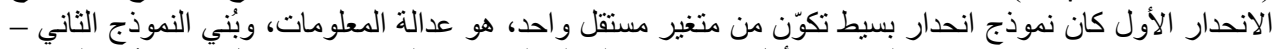

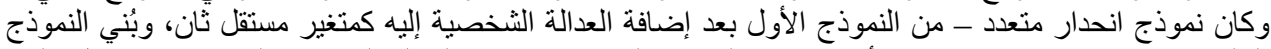

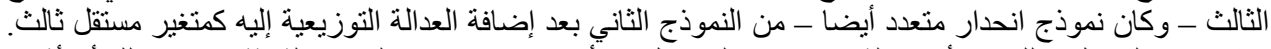

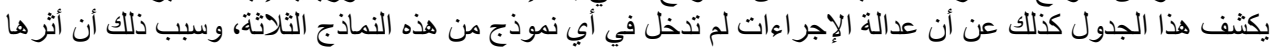
في الالتز ام الوظيفي لم يكن ذا دلالة إحصائية. الجدول (59): متغيرات نموذج الانحدار المتعدد المستقلة وأسس الإدراج والحذف

\begin{tabular}{|c|c|c|c|}
\hline \multirow{2}{*}{ مقياس الإدراج أو الطرح } & \multicolumn{2}{|c|}{ المتغيرات المستقلة للنموذج } & \multirow[b]{2}{*}{ النموذج } \\
\hline & المطروحة & المدرجة & \\
\hline \multirow{3}{*}{ 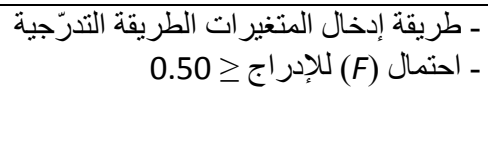 } & \multirow{3}{*}{ عدالة الإجر اءات } & عدالة المعلومات & 1 \\
\hline & & العدالة الثخصية & 2 \\
\hline & & العدالة التوزيعية & 3 \\
\hline
\end{tabular}

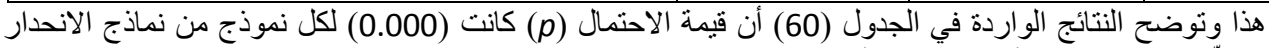

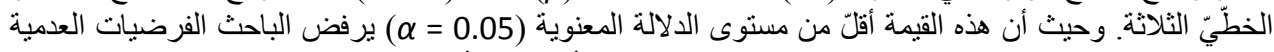

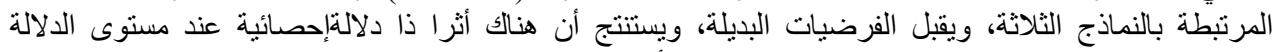

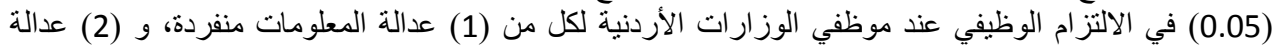

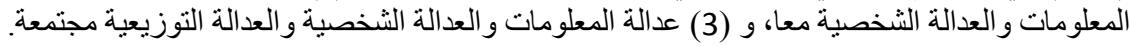


The Influence of Organizational Justice on Job Commitment in the Jordanian Ministries

الجدول (60): تحليل التباين (ANOVA) في نموذج أثر أبعاد العدالة التنظيمية في الالتزام الوظيفي

\begin{tabular}{|c|c|c|c|c|c|c|}
\hline 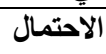 & الدّالّ الإحصائي (F) & المريع المتوسط & درجة الحرّيّة & مجموع المربّعات & \multicolumn{2}{|c|}{ النموذج } \\
\hline & \multicolumn{6}{|c|}{ المتغير التابع: الالتزام الوظيفي ـ المتغير المستقل: عدالة المعلومات } \\
\hline 0.000 & 159.725 & 10930.489 & 1 & 10930.489 & الانحدار & 1 \\
\hline & & 68.433 & 380 & 26004.548 & المتبقِي & \\
\hline & & & 381 & 36935.037 & الكلَّيّ & \\
\hline
\end{tabular}

\begin{tabular}{|c|c|c|c|c|c|c|}
\hline & \multicolumn{6}{|c|}{ المتغير التابع: الالتزام الوظيفي- المتغيرات المستقلة: عدالة المعلومات، والعدالة الثخصية } \\
\hline 0.000 & 98.109 & 6299.632 & 2 & 12599.264 & الاتحدار & 2 \\
\hline & & 64.210 & 379 & 24335.773 & المتبقِّي & \\
\hline & & & 381 & 36935.037 & الكلَّيّ & \\
\hline
\end{tabular}

\begin{tabular}{|c|c|c|c|c|c|c|}
\hline & \multicolumn{6}{|c|}{ المتغير التابع: الالتزام الوظيفي- المتغيرات المستقلة: عدالة المعلومات، والعدالة الثخصية، } \\
\hline 0.000 & 68.871 & 4351.169 & 3 & 13053.507 & الاتحدار & 3 \\
\hline & & 63.179 & 378 & 23881.530 & المتبقِي & \\
\hline & & & 381 & 36935.037 & الكلَّيّ ل الكَّ & \\
\hline
\end{tabular}

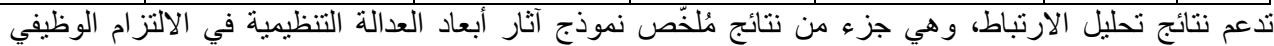

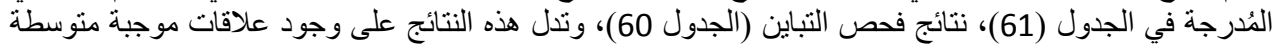

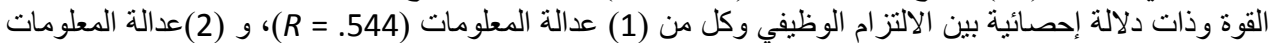

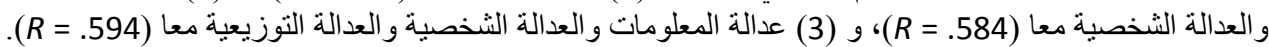

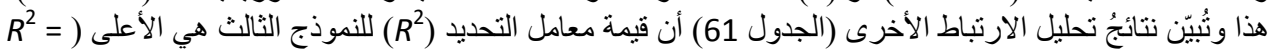

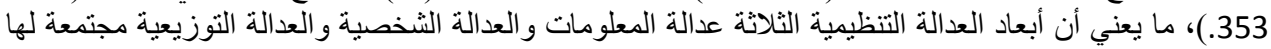

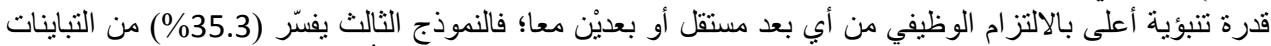

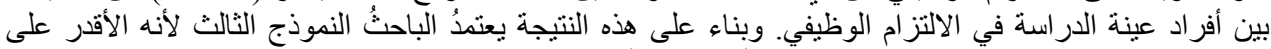

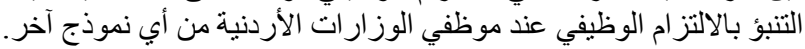

الجدول (61): مُلخّص نماذج آثار أبعاد العدالة التنظيمية في الالتزام الوظيفي

\begin{tabular}{|c|c|c|c|}
\hline النموذج (3)**** & النموذج (2) & النموذج (1)" & النموذج \\
\hline 0.594 & 0.584 & 0.544 & معامل الارتباط (R) \\
\hline 0.353 & 0.341 & 0.296 & معامل التحديا (R2) \\
\hline 0.348 & 0.338 & 0.294 & معامل التحديد المعدل \\
\hline \multicolumn{4}{|c|}{ 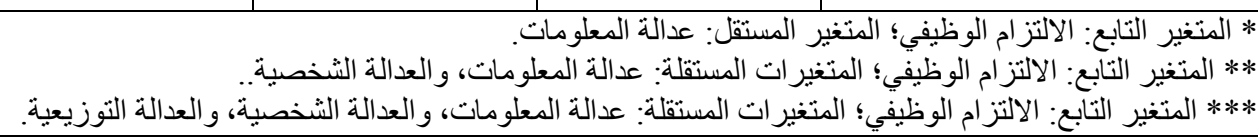 } \\
\hline
\end{tabular}

يوجز الجدول (62) قيم المعاملات (الميول والقو اطع الصنّاديّة) لنماذج الانحدار الخطي الثلاثة قيد الدراسة التي تتنبأ

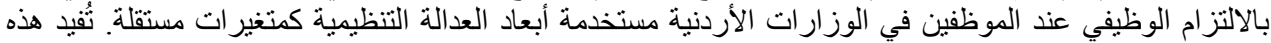
المعاملات في صياغة معادلات كل نموذج من هذه النماذج، وبناء على هذه النتائج فإن معادلة النموذج الثالثة الثان غير

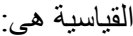
الالتزام الوظيفي = 20.471 + 0.684 * عدالة المعلومات + 0.679 * العدالة الثخصية + 0.359 * العدالة 


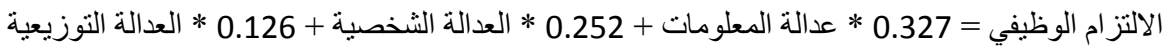
الجدول (62): مُعامِلات نماذج آثار أبعاد العدالة التنظيمية في الالتزام الوظيفي

\begin{tabular}{|c|c|c|c|c|c|c|}
\hline \multirow[t]{2}{*}{ الاحتمال (p) } & \multirow[t]{2}{*}{ تاء (t) } & \multirow{2}{*}{ 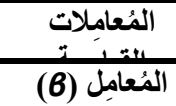 } & \multicolumn{2}{|c|}{ المُعامِلات غير القياسية } & \multirow{2}{*}{\multicolumn{2}{|c|}{ النموذج }} \\
\hline & & & الخطأ & (B) J & & \\
\hline 0.000 & $\begin{array}{c}20.18 \\
6\end{array}$ & & 1.387 & 27.991 & الثّاديت (القاطع & 1 \\
\hline 0.000 & 12.63 & 0.544 & 0.090 & 1.138 & عدالة المعلومات & \\
\hline 0.000 & $\begin{array}{c}12.77 \\
3\end{array}$ & & 1.746 & 22.304 & الثَاديت (القاطع & 2 \\
\hline 0.000 & 6.870 & 0.370 & 0.113 & 0.774 & عدالة المعلومات & \\
\hline 0.000 & 5.098 & 0.275 & 0.145 & 0.739 & العدالة الثخصية & \\
\hline 0.000 & $\begin{array}{c}10.99 \\
4\end{array}$ & & 1.862 & 20.471 & الصّابت (القاطع & 3 \\
\hline 0.000 & 5.857 & 0.327 & 0.117 & 0.684 & عدالة المعلومات & \\
\hline 0.000 & 4.663 & 0.252 & 0.146 & 0.679 & العدالة الثخصية & \\
\hline 0.008 & 2.681 & 0.126 & 0.134 & 0.359 & العدالة التوزيعية & \\
\hline
\end{tabular}

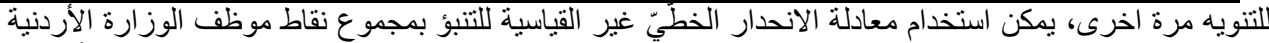

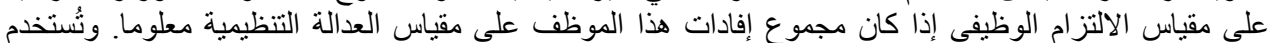

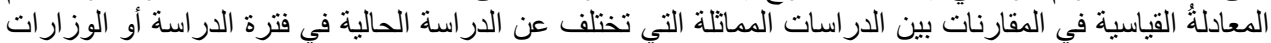

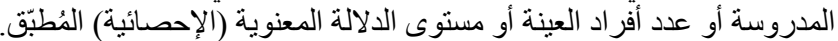

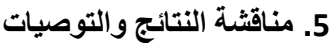

5.1

في هذا البحث سوف يناقش الباحث نتائج اختبار التحليل الإحصائي، ثم يقدم التوصيات و المحددات البحثية و الإسهامات

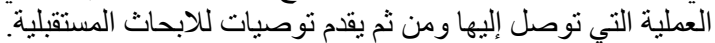

5.2

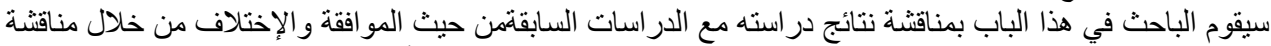

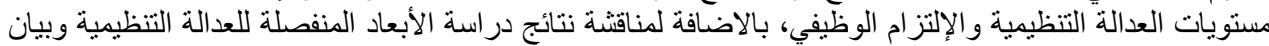
الفروقات ومقدار تأثير ها في أبعاد الإلتز ام الوظيفي الإليفي.

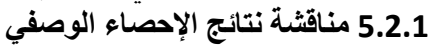

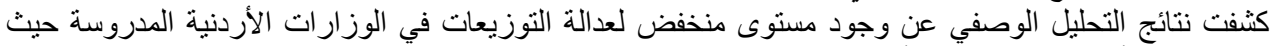

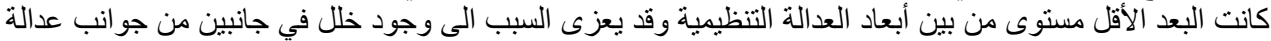

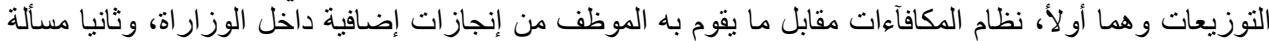

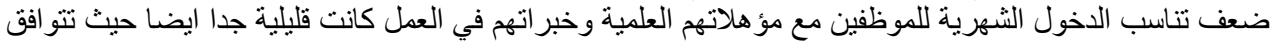

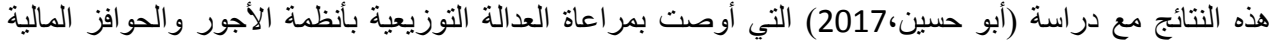

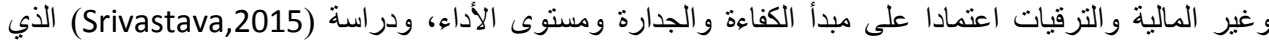

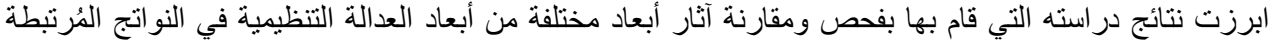

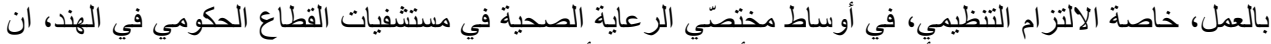

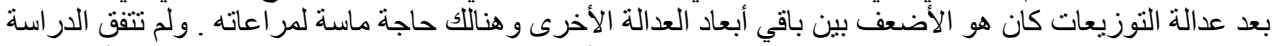

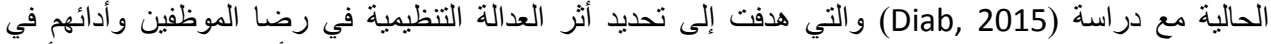

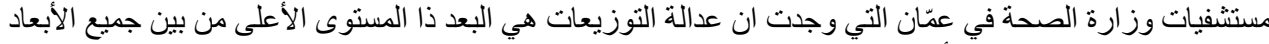

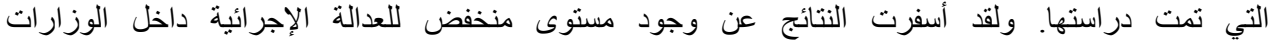

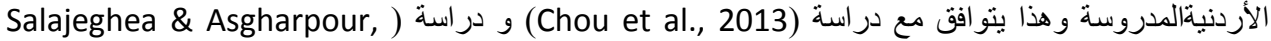

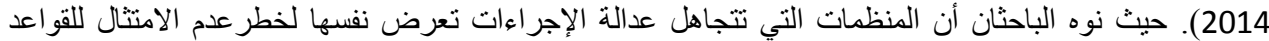

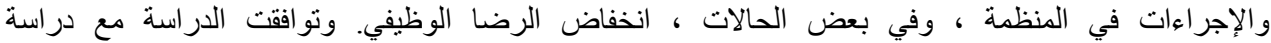
(القهيوي،2015) و التي هدف بها للتعرف على مستوى إدر الك العاملين للعدالة التنظيمية وأبعادها في شركات البوتاس 


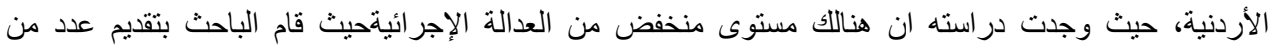

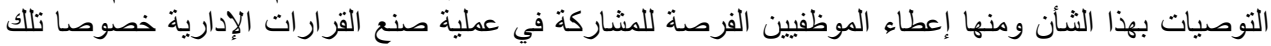

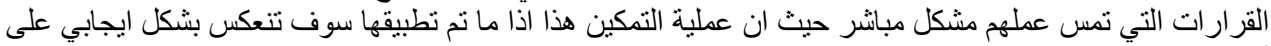

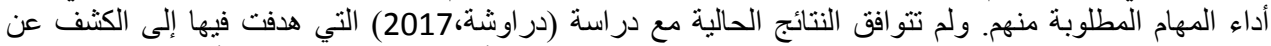

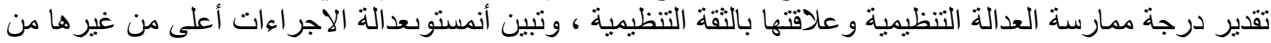

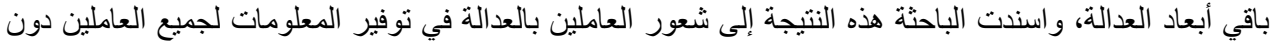

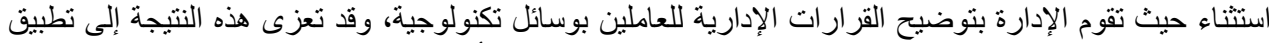

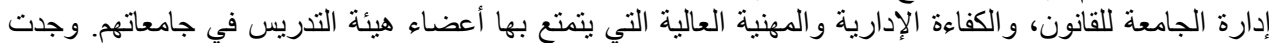

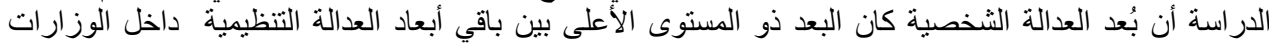

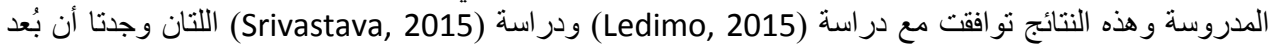

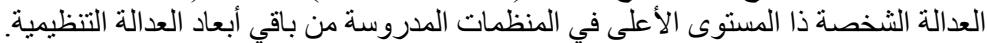

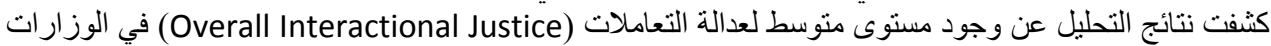

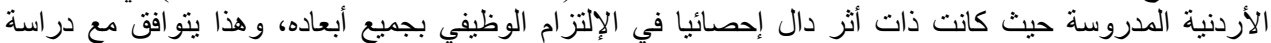

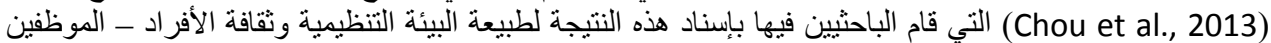

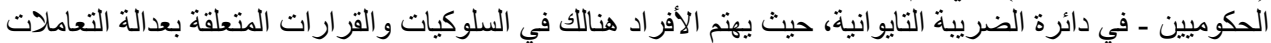

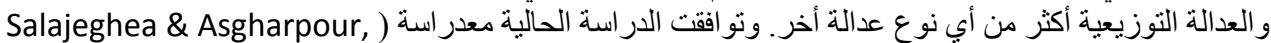

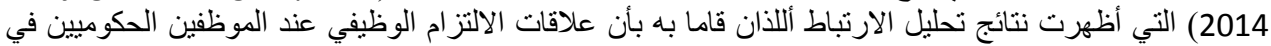

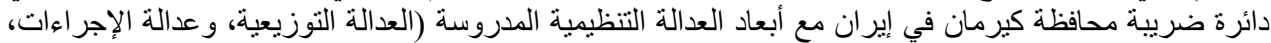

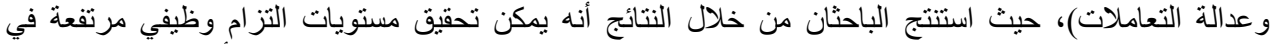

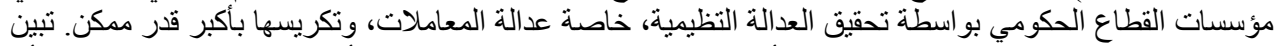

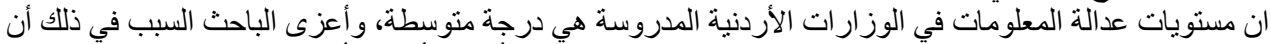

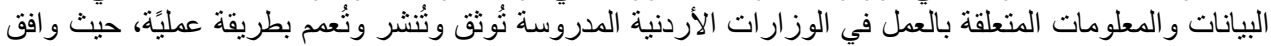

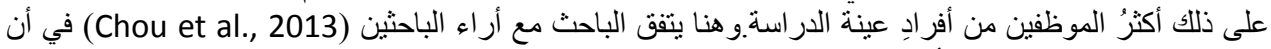

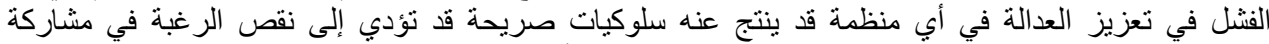

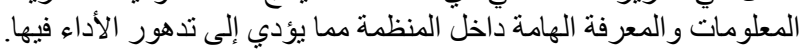
5.2.2

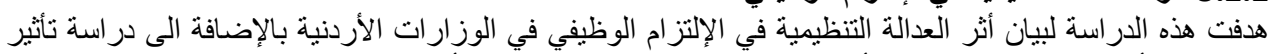

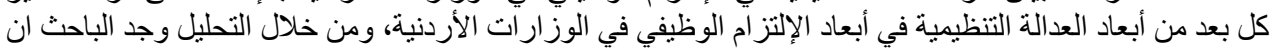

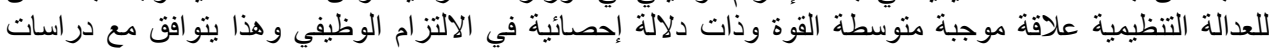

.(Salajeghea \& Asgharpour ,2014 ; Chou et al., 2013; Mukherjee et al. ,2016) 5.2.3 أثر أبعاد العدالة التظيمية في أبعاد الإلتزام الوظيفي

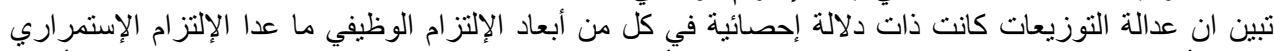

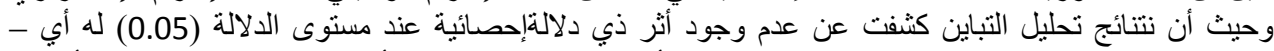

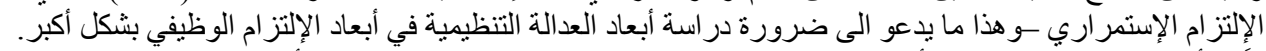

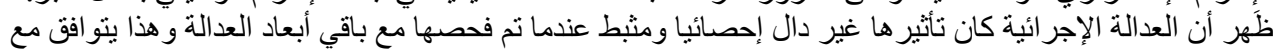

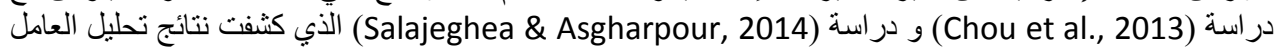

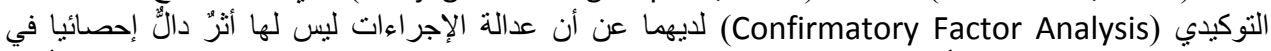

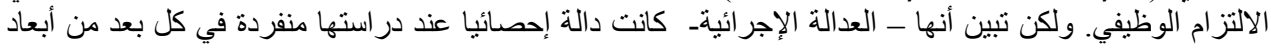

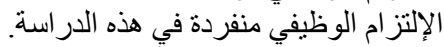

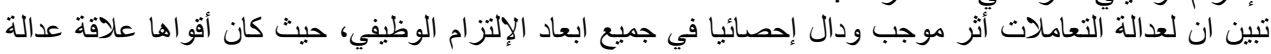

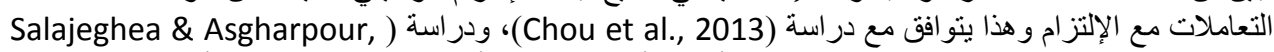
2014)، التي وجدت الن عدالة التعاملات هي الأقوى تأثثر بين باقي أبعاد العدالة التنظيمية الأخرى في الإلتزام

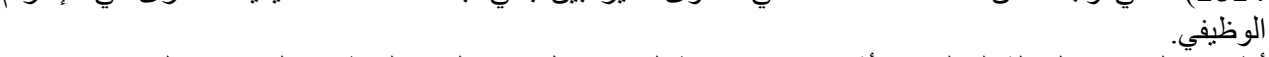
أظهرت النتائج ان لعدالة المعلومات أثر موجب منوسط القوة في كل من الإلتز ام العاطفي و المعياري ولكنها كانت ذات

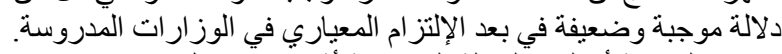

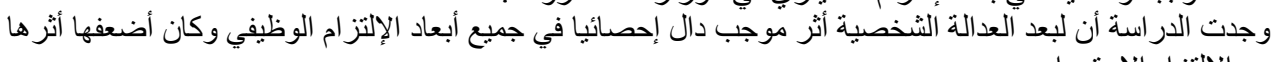

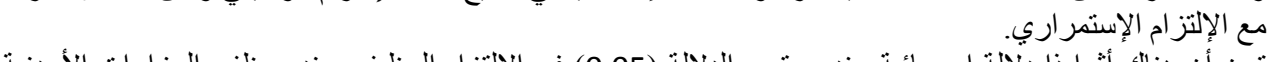

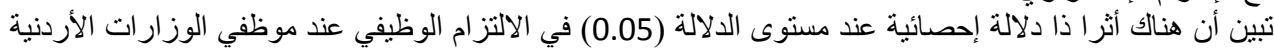

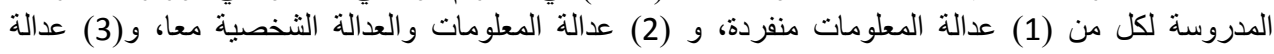




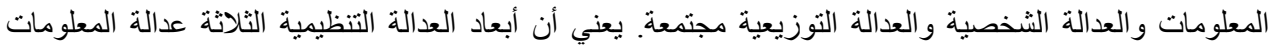

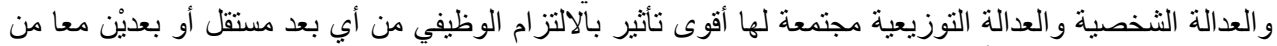
العدالة التنظيمية، وان لهم أكبر قدرة تنبؤية في الإلتز ام الوظيفي.

(ب التوصيات

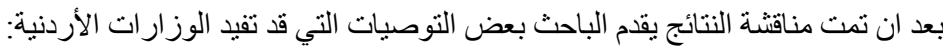

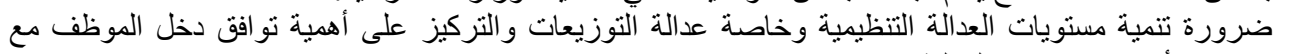
مستو اه الأكاديمي وخبرته منته العملية.

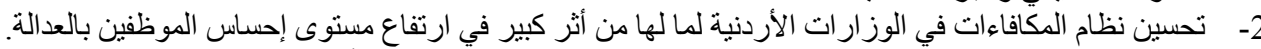

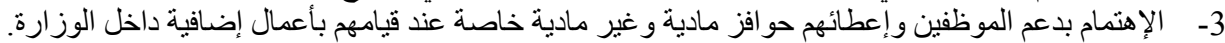

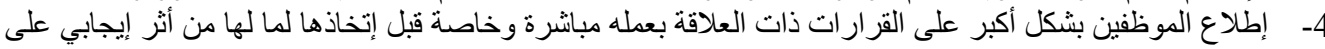
إلتزامه الوطيفي. إلتز امه الوظيفي.

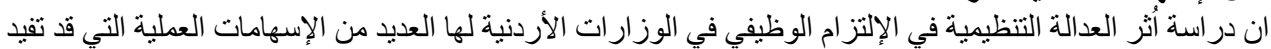

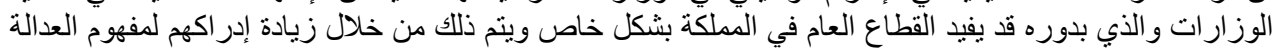

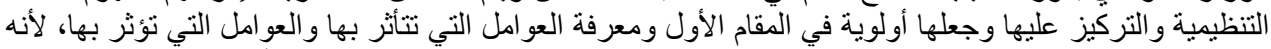

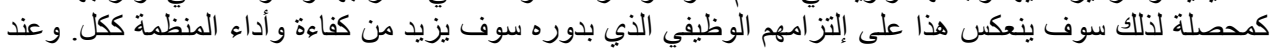

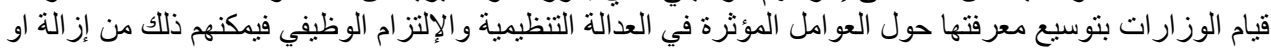

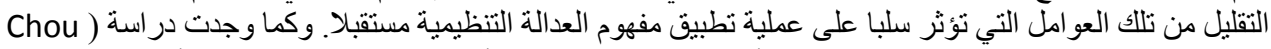
(et al., 2013

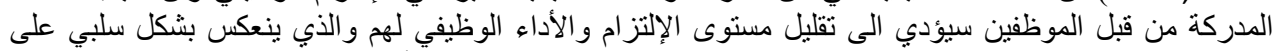

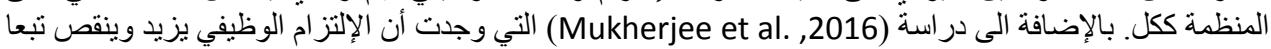

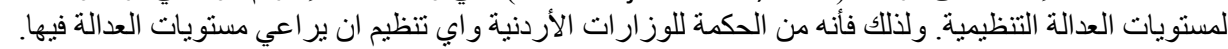
5.5

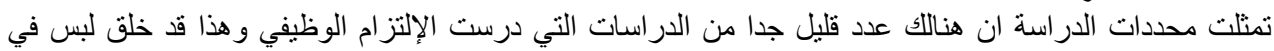

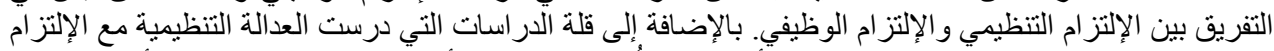

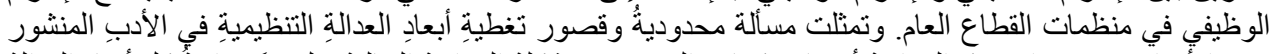

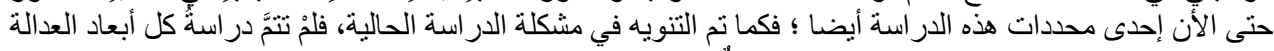

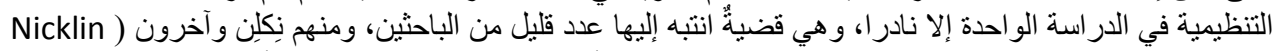

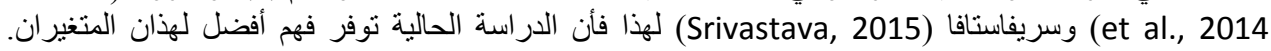

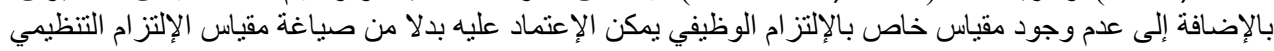
بشكل يتناسب مع الإلتز ام الوظيفي. 1- ضرورة إجراء أبحاث بصورة أُكبر على الإلتزام الوظيفي وبيان الفرق بينه وبين أنواع الإلتزام الأخرى مثل الإلتزام التنظيمي.

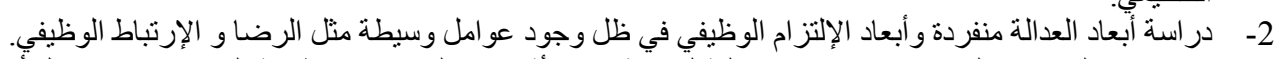

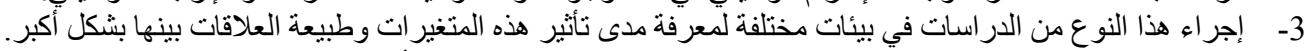

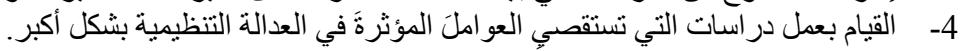

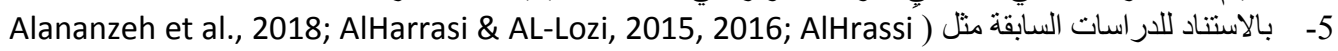
(et al., 2016; AL-Syaidh et al., 2016; Ammari et al., 2017 ; Altamony \& Gharaibeh, 2017 أولا: المراجع العيل اساليب الادارة الحديثة من أجل تحقيق الإلتز ام الوظيفي الأمثل. أبو حسين، ا. م. م. (2017). أثر الثر العدالة التنظيمية على الفاعلية التنظيمية في الثركات الصناعية المساهمة العامة الأردنية.

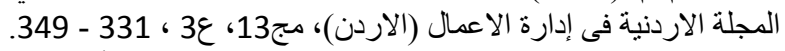

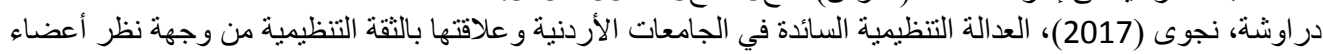

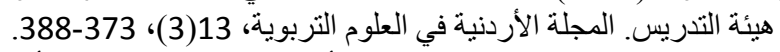

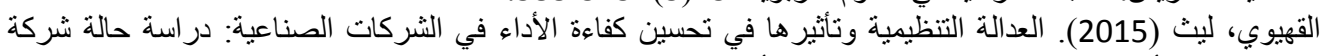

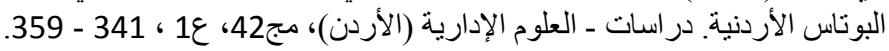

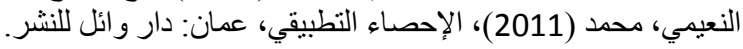




\section{References}

ثانيا: المراجع الأجنبية

Alananzeh, O., Jawabreh, O., Al-Mahmoud, A., \& Hamada, R. (2018). The Impact of Customer Relationship Management on Tourist Satisfaction: The Case of Radisson Blue Resort in Aqaba City. Journal of Environmental Management and Tourism, 2(26), 227240.

AlHarrasi, J., \& AL-Lozi, M. (2015). The Role of Innovation Management and Technological Innovation on Organizational Effectiveness. 4th Scientific \& Research Conference on New Trends in Business, Management and Social Sciences (COES\&RJTK15/1), Istanbul, Turkey.

AlHarrasi, J., \& AL-Lozi, M. (2016). The Role of Innovation Management and Technological Innovation on Organizational Effectiveness: A Theoretical Model. Journal of Social Sciences (COES\&RJ-JSS), 5(1), 80-95.

AlHrassi, J., Al-Lozi, M., \& Irtaimeh, H. (2016). The Impact of Management Innovation and Technological Innovation on Organizational Effectiveness: An Empirical Study from Managerial Staff Perspective in Sultan Qaboos University. Journal of Social Sciences (COES\&RJ-JSS), 5(3), 309-339.

Almajali, D., Mansour, K., \& Maqableh, M. (2016). The Impact of Electronic Supply Chain Management Usage on Firm's Performance. International Journal of Communications, Network and System Sciences, 9(6), 280-293.

AL-Syaidh, N., Al- Lozi, M., \& AlHarrasi, J. (2016). Transformational Leadership and its Role on the Effectiveness of Employees' Behavior: A Theoretical Study. Journal of Business \& Management (COES\&RJ-JBM), 4(1), 14-35.

Altamony, H., \& Gharaibeh, A. (2017). The Role of Academic Researcher to Mintzberg's Managerial Roles. International Journal of Business Management and Economic Research, 8(2), 920-925.

Ammari, G., Alkurdi, B., Alshurideh, M., \& Alrowwad, A. (2017). Investigating the Impact of Communication Satisfaction on Organizational Commitment: A Practical Approach to Increase Employees' Loyalty. International Journal of Marketing Studies, 9(2), 113-133.

Beavers, A.S., Lounsbury, J.W., Richards, J.K., Huck, S.W., Skolits, G.J., \& Esquivel, S.L. (2013). Practical Considerations for Using Exploratory Factor Analysis in Educational Research. Practical Assessment, Research \& Evaluation, 18(6), 1-13.

Chou, T., Chou, S.T., Jiang, J.J., \& Klein, G. (2013). The Organizational Citizenship Behavior of IS Personnel: Does Organizational Justice Matter? Information \& Management, 50, 105-111. 
Coetzee, M., Schreuder, D., \& Tladinyane, R. (2014). Employees' Work Engagement and Job Commitment: The Moderating Role of Career Anchors. Journal of Human Resource Management, 12(1), 1-12.

Costello, A.B., \& Osborne, J.W. (2005). Best Practices in Exploratory Factor Analysis: Four Recommendations for Getting the most from your Analysis. Practical Assessment, Research and Evaluation, 10(7).

Cronbach, L. (1970). Essentials of Psychology Testing. Harper \& Row, New York, USA.

Diab, S.M. (2015). The Impact of Organizational Justice on Workers Performance and Job Satisfaction in the Ministry of Health Hospitals in Amman. International Business Research, 8(2), 187-197.

Field, A. (2005). Discovering Statistics Using SPSS. 2nd Edition, Sage, London.

Fornell, C., \& Larcker, F. (1981). Evaluating Structural Equation Models with Unobservable Variables and Measurement Error. Journal of Marketing Research, 18(1), 39-50.

Hair, J.F., Black, B., Babin, B., Anderson, R.E., \& Tatham, R.L. (2005). Multivariate Data Analysis. NJ: Prentice Hall.

Hinton, P.R., Brownlow, C., McMurray, I., \& Cozens, B. (1980). SPSS Explained, Routledge, London.

Hinton, P.R., Brownlow, C., McMurvay, I., \& Cozens, B. (2004). SPSS Explained, East Sussex, England: Routledge Inc.

Kaiser, H.F. (1960). The Application of Electronic Computers to Factor Analysis. Educational and Psychological Measurement, 20(1), 141-151.

Kaiser, H.F. (1974). An Index of Factorial Simplicity. Psychometrika, 39(1), 31-36.

Krejcie, R.V., \& Morgan, D.W. (1970). Determining Sample Size for Research Activities. Educational and Psychological Measurement, 30, 607-610.

Ledimo, O.M. (2015). An Exploratory Study of Factors Influencing Organizational Justice among Government Employees. The Journal of Applied Business Research, 31(4), 15491562.

McNeil, V.H., Cox, M.E., \& Preda, M. (2005). Assessment of Chemical Water Types and their Spatial Variation Using Multi-Stage Cluster Analysis, Queensland, Australia. Journal of Hydrology, 310(1-4), 181-200.

Mowday, R.T., Porter, L.W., \& Steers, R.M. (1982). Employee-Organization Linkage, The Psychology of Commitment Absenteeism, and Turn over, London: Academic Press Inc. 
Mukherjee, S., Singh, A., \& Mehrotra, S. (2016). Organizational Justice in relation to Competence, Commitment and Self Motivation. The International Journal of Indian Psychology, 3(2), 33-59.

Nicklin, J.M., McNall, L.A., Cerasoli, C.P., Strahan, S.R., \& Cavanaugh, J.A. (2014). The Role of Overall Organizational Justice Perceptions within the Four-Dimensional Framework. Social Justice Research, 27, 243-270.

Niehoff, B.P., \& Moorman, R.H. (1993). Justice as a Mediator of the Relationship between Methods of Monitoring and Organizational Citizenship Behavior. Academy of Management Journal, 36(3), 527-556.

Nunnaly, J. (1978). Psychometric Theory. New York: McGraw-Hill.

Obeidat, O., Sweis, R., Zyod, D., \& Alshurideh, M. (2012). The Effect of Perceived Service Quality on Customer Loyalty in Internet Service Providers in Jordan. Journal of Management Research, 4(4), 224-242.

Oludeyi, O.S. (2015). A Reviewof Literature on Work Environmentand Work Commitment: Implication for Future Research in Citadels of Learning. Journal of Human Resource Management, 18(2), 32-46.

Rai, G.S. (2013). Impact of Organizational Justice on Satisfaction, Commitment and Turnover Intention: Can Fair Treatment by Organizations make a Difference in their Workers' Attitudes and Behaviors? International Journal of Human Sciences, 10(2), 260284.

Reichers, A.E. (1985). A Review and Conceptualization of Organizational Commitment. Academy of Management Review, 10, 465-476.

Reimann, C., Filzmoser, P., Garrett, R.G. (2002). Factor Analysis Applied to Regional Geochemical Data: Problems and Possibilities. Applied Geochemistry, 17(3), 185-206.

Salajeghea, S., \& Asgharpour, L. (2014). Studying the Relationship between Organizational Justice and Staff Job Commitment a Case Study of Kerman State Tax Administration Staff. Scientific Journal of Review, 3(8), 898-908.

Srivastava, U.R. (2015). Multiple Dimensions of Organizational Justice and Work-Related Outcomes among Health-Care Professionals. American Journal of Industrial and Business Management, 5, 666-685.

Tabachnick, B.G., \& Fidell, L.S. (2007). Using Multivariate Statistics (5th ed.). Boston, MA: Allyn \& Bacon.

Tarhini, A., Al-Badi, A., Almajali, M., \& Alrabayaah, S. (2017). Factors Influencing Employees' Intention to Use Cloud Computing. Journal of Management and Strategy, $8(2), 47$. 
Umoh, G.I., Amah, E., \& Wokocha, I.H. (2014). Employee Benefits and Continuance Commitment in the Nigerian Manufacturing Industry. IOSR Journal of Business and Management, 16(2), 69-74.

Wu, M.L. (2008). The Practice of Multivariate Analysis. Taipei: Wu-Nan Book.

Yong, A.G., \& Pearce, S. (2013). A Beginner's Guide to Factor Analysis: Focusing on Exploratory Factor Analysis. Tutorials in Quantitative Methods for Psychology, 9(2), 7994.

Yusoff, M.S. (2011). Psychometric Properties of the Learning Approach Inventory: A Confirmatory Factor Analysis. Education in Medicine Journal, 3(2), 24-31.

Zhang, Y., Zhang, J., Lease, M., \& Gwizdka, J. (2014). Multidimensional Relevance Modeling via Psychometrics and Crowdsourcing. Proceedings of the $37^{\text {th }}$ International ACM SIGIR Conference on Research and Development in Information Retrieval, ACM SIGIR '14, 06-11 July 2014, pp. 435-444. Gold Coast, QLD, Australia. 